\title{
Understanding Forest Health with Remote Sensing -Part I-A Review of Spectral Traits, Processes and Remote-Sensing Characteristics
}

\author{
Angela Lausch ${ }^{1, *}$, Stefan Erasmi ${ }^{2}$, Douglas J. King ${ }^{3}$, Paul Magdon ${ }^{4}$ and Marco Heurich 5 \\ 1 Department Computational Landscape Ecology, Helmholtz Centre for Environmental Research-UFZ, \\ Permoserstr. 15, D-04318 Leipzig, Germany \\ 2 Institute of Geography, Cartography GIS \& Remote Sensing Sect, Georg-August-University Göttingen, \\ Goldschmidtstr. 5, D-37077 Göttingen, Germany; serasmi@gwdg.de \\ 3 Depterment of Geography and Environmental Studies, Geomatics and Landscape Ecology Lab, \\ Carleton University, 1125 Colonel By Drive, Ottawa, ON K1S 5B6, Canada; doug.king@carleton.ca \\ 4 Chair of Forest Inventory and Remote Sensing, Georg-August-University Göttingen, Büsgenweg 5, \\ D-37077 Göttingen, Germany; pmagdon@gwdg.de \\ 5 Bavarian Forest National Park, Department of Conservation and Research, Freyunger Straße 2, \\ D-94481 Grafenau, Germany; marco.heurich@npv-bw.bayern.de \\ * Correspondence: angela.lausch@ufz.de; Tel.: +49-341-235-1961; Fax: +49-341-235-1939
}

Academic Editors: Lars T. Waser, Clement Atzberger and Prasad S. Thenkabail

Received: 6 September 2016; Accepted: 5 December 2016; Published: 18 December 2016

\begin{abstract}
Anthropogenic stress and disturbance of forest ecosystems (FES) has been increasing at all scales from local to global. In rapidly changing environments, in-situ terrestrial FES monitoring approaches have made tremendous progress but they are intensive and often integrate subjective indicators for forest health (FH). Remote sensing (RS) bridges the gaps of these limitations, by monitoring indicators of FH on different spatio-temporal scales, and in a cost-effective, rapid, repetitive and objective manner. In this paper, we provide an overview of the definitions of FH, discussing the drivers, processes, stress and adaptation mechanisms of forest plants, and how we can observe FH with RS. We introduce the concept of spectral traits (ST) and spectral trait variations (STV) in the context of FH monitoring and discuss the prospects, limitations and constraints. Stress, disturbances and resource limitations can cause changes in FES taxonomic, structural and functional diversity; we provide examples how the ST/STV approach can be used for monitoring these FES characteristics. We show that RS based assessments of FH indicators using the ST/STV approach is a competent, affordable, repetitive and objective technique for monitoring. Even though the possibilities for observing the taxonomic diversity of animal species is limited with RS, the taxonomy of forest tree species can be recorded with RS, even though its accuracy is subject to certain constraints. RS has proved successful for monitoring the impacts from stress on structural and functional diversity. In particular, it has proven to be very suitable for recording the short-term dynamics of stress on $\mathrm{FH}$, which cannot be cost-effectively recorded using in-situ methods. This paper gives an overview of the ST/STV approach, whereas the second paper of this series concentrates on discussing in-situ terrestrial monitoring, in-situ RS approaches and RS sensors and techniques for measuring ST/STV for FH.
\end{abstract}

Keywords: forest health; forest ecosystem; earth observation; remote sensing; traits; spectral traits (ST); spectral trait variations (STV); non-spectral traits (N-ST)

\section{Introduction}

About one third of the Earth's land surface is covered by forests [1]. They provide important ecosystem services, such as carbon sequestration, habitat for species that contribute to maintaining 
biodiversity, mitigating climate change and the ability to filter and maintain water resources [2,3]. However, forests are facing numerous threats and stress factors such as deforestation [4], drought [5] climate change [6], invasive species [7] susceptibility to pests and pathogens [8,9], air pollution [10], disturbance-induced mortality from fire, water or windthrow [8] land-use changes [11] or unsustainable management [12].

The conservation and improvement of key forest functions is therefore imperative, as healthy forests are more stable and resilient to various stress types, disturbance and resource limitations. Given the global importance of forests and the expected increase in threats, the implementation of sustainable forest management is vital to our future. It therefore follows that forest ecosystem health has gained popular attention over recent years with growing concerns about air pollution, acid rain, global climate change, population growth, and long-term resource management. In response to these environmental concerns and to current legislative and policy directions, federal and state agencies worldwide have been working together to develop programs for monitoring and reporting on the status and trends of forest ecosystem health. The United States national Forest Health Monitoring (FHM) program, for example, was established to accomplish this objective $[13,14]$. The FOREST EUROPE program of the European Union, the International Co-operative Programme on Assessment and Monitoring of Air Pollution Effects on Forests (EU/ICP Forests) [15], and the Chinese national program on ecological functions [16] are large programs for monitoring and assessing forest health.

Numerous definitions of forest health exist, ranging from the recording of economic-related indicators [17] to ecological-function indicators that preserve resilience and stability $[3,18]$. Kolb et al., [18] name four qualitative indicators of FH: (i) "The physical environment, biotic resources, and trophic networks to support productive forest during at least some seral stages; (ii) The resistance to catastrophic change and/or the ability to recover from catastrophic change at the landscape level; (iii) A functional equilibrium between the supply and demand of essential resources; and (iv) a diversity of seral stages and stand structures that provide habitat for many native species and all essential ecosystem processes". Trumbore et al., [2], on the other hand, characterised FH as a "mosaic of successional patches representing all stages of the natural range of disturbance and recovery". On the tree scale, health is often defined as the absence of disease or damage, but if this concept is applied to forest stands or landscapes, the indicators of FH are more difficult to assess [2]. In forestry, widely used health indicators on the stand level are yield measures or metrics representing the health status of tree crowns. Examples include the visible assessment of infestation levels, leaf defoliation, leaf chlorosis and other discolouration, dead branches, trunk damage, or the quantitative assessment of canopy damage or deterioration using metrics such as leaf area index, crown closure, numbers and volume of standing, dead and fallen trees. However, for a comprehensive description of FH, such an indicator set should also include utilitarian as well as ecosystem indicators, which have to be implemented across different spatial scales. The above definition (absence of disease or damage) is essentially binary, but in practice it is desired to assess $\mathrm{FH}$ on an interval or ratio scale, and the definition of such scales often includes subjective elements.

Altered structures, functions or taxonomy are present on all spatial levels of forest diversity-from the molecular level to the landscape level and biomes. Therefore, a holistic approach as well as a global strategy are imperative when it comes to monitoring FH and defining the indicators that need to be observed [9]. To assess FH and to understand the influence of different stress factors, a monitoring system which combines in-situ terrestrial observations and remote-sensing technologies is crucial $[2,9,19]$. While in-situ terrestrial forest monitoring is generally applied on a plot level, RS approaches provide wall-to-wall information on multiple temporal and spatial scales $[3,20,21]$.

There are a wide range of RS applications to measure FH indicators [22], while at the same time the number and availability of high quality RS data is constantly growing [23-27]. Furthermore, there are numerous methodology approaches that use RS technologies for long-term monitoring of FH [28-31]. In recent years, the development of RS technologies and applications has gained advantage from the opening of large RS-data archives to the public (e.g., Landsat) [32,33]), including entire space missions 
developed for the public domain (e.g., the Sentinel Missions of the European Space Agency (ESA) [34]) as well as the development of open source tools for processing RS data [35]. As a consequence of such developments it can be expected that they will lead to a tremendous impetus in the use of RS techniques for understanding FH [33].

Generally, the spatial, spectral and thematic resolution that can be reliably assessed by RS decreases as the required spatial extent increases. Local to regional FH assessments can use sensors with small area coverage and high spatial resolution, while global assessments are conducted at coarse scales. Recently developed sensors such as Worldview-3 provide more than 10 spectral bands over the visible-near infrared-short wave infrared regions of the spectrum with very high spatial resolution (0.3-2.5 m pixel size). However, their limited coverage per image (10-20 km swath) makes this type of imagery only suitable for local and regional mapping. Lower spatial resolution satellite-based hyperspectral, polarimetric, RADAR and LiDAR sensors have been developed and launched and more are under development for the near future. These have the potential to significantly improve the information content relevant to FH assessment over broader spatial scales.

In monitoring $\mathrm{FH}$, in-situ forest condition surveys and RS based approaches are fundamentally different. As a physically-based system, RS follows regulations, mechanisms and constraints that have to be in the context of FH. The goal of this paper is to demonstrate how RS can be used to monitor and understand FH. To illustrate this, we consider the following research questions: (i) How can forest health be defined? What are its mechanisms, drivers and processes? On which spatial and temporal scales should indicators of forest health be measured? (ii) Why and under which conditions are remote-sensing approaches suitable for observing indicators of forest health? (iii) What is the concept of spectral traits (ST) and spectral trait variations (STV) for quantifying, monitoring and assessing forest health using remote sensing? Through addressing these questions, we discuss the usability of the ST/STV approach to measure stress and disturbances in taxonomic, structural and functional diversity of FES.

\section{Understanding Forest Health}

In order to quantify and assess FH, a clear and unambiguous definition is needed. One approach is to understand $\mathrm{FH}$ as a component of FES. A stable ecosystem can be characterized by its high resistance and resilience to disturbance. The greater its resilience, the quicker the system can return to its initial state following an external disturbance and any resulting changes to its systemic nature. The greater its resistance, the greater the system's capability of withstanding the negative impacts from external influences [36]. Those ecosystems that are more complex and more diverse (more species, communities and food chains) are usually more stable (given a few exceptions). Positive feedbacks of biodiversity on the functionality of ecosystems have been analysed in different biodiversity-ecosystem functioning (BEF) experiments [37-39]. The BEF experiments are primarily concerned with fast-growing primary producer systems $[40,41]$ whereas interactions or disturbances to slow-growing FES on ecosystem services such as climate regulation, carbon storage, water filtration or erosion control without RS methods are still insufficiently understood [42-44]. A proper understanding of $\mathrm{FH}$, as well as its stability or instability requires knowledge of the following factors: (i) the characteristics of forest ecosystem diversity-taxonomy, structure and functional diversity as well as their meaning for FH; (ii) the influence of phylogenetic information from forest species, which defines their potential for adaptation and reaction to multiple stress factors; (iii) drivers, processes and their characteristics, which affect $\mathrm{FH}$; and (iv) the time frame of the monitoring conducted.

\subsection{Characteristics of Forest Ecosystem Diversity}

To assess FH, the characteristics of FES diversity, the taxonomic, structural and functional diversity provide us with important indications of adaptation mechanisms, stress or irreversible changes. FES are characterized by their different organizational levels such as the molecular, genetic, individual, species, population, community, ecosystem, landscape and biome levels, which consist of three 
essential characteristics (Figure 1). Taxonomic diversity of FES refers to the diversity of biotic entities of forest ecosystems, structural diversity explains the arrangement and distribution (composition and configuration) of the structure of biotic entities in FES, and functional diversity describes the realized ecological functions and processes in FES. These characteristics help us to understand the importance of taxonomy, structure, functions and processes for maintaining entire forest systems and the shifts, disturbances and crucial changes that can lead to disturbances or irreversible impairment of FES $[45,46]$.

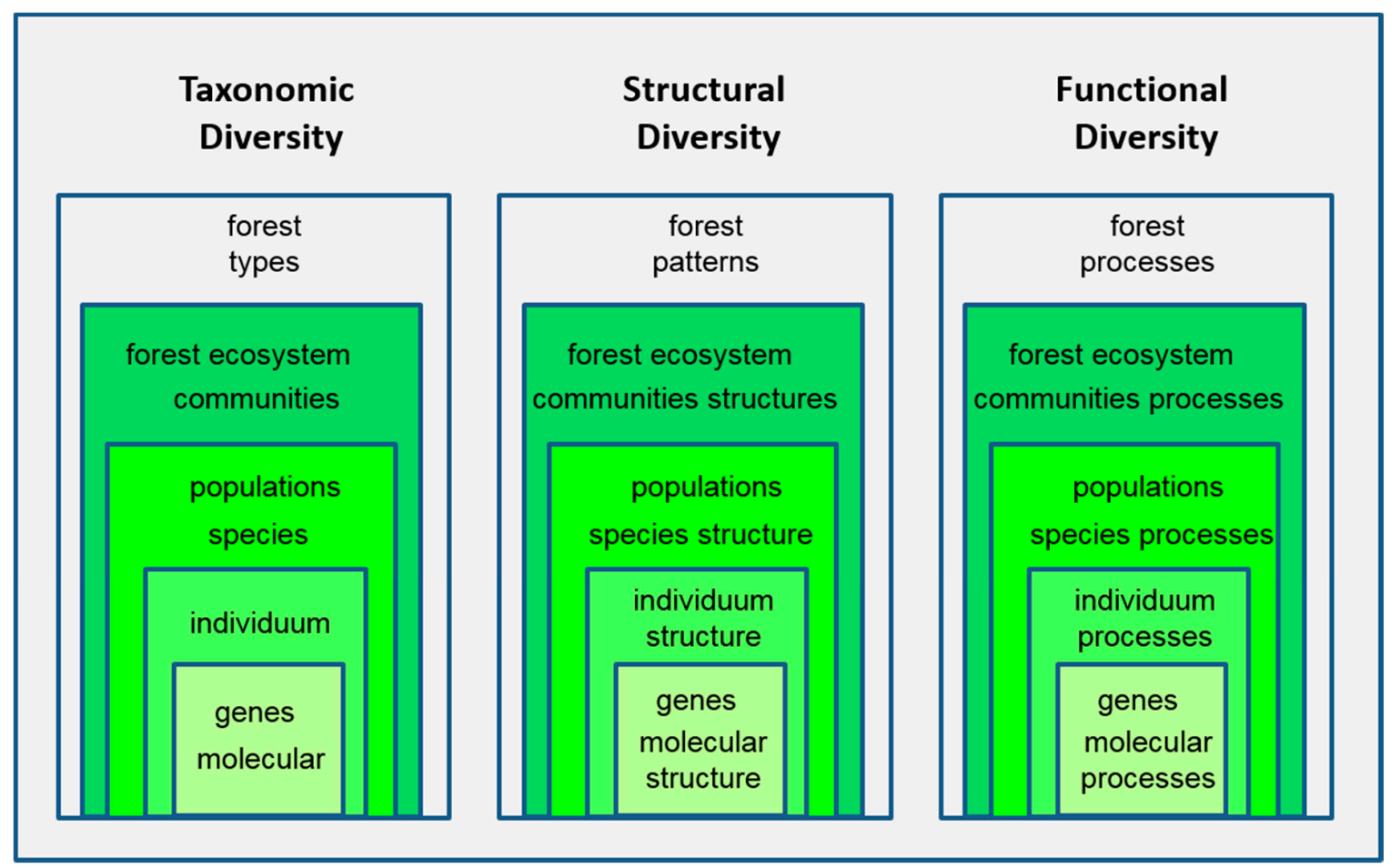

Figure 1. The essential characteristics of diversity in forest ecosystems-Taxonomic Diversity, Structural Diversity and Functional Diversity on different levels of organization in terms of the biotic features of the forest-molecular, genetic, individual, species, populations, communities, biomes, ecosystems and landscapes (modified after Noss [45] and Lausch [46]).

\subsection{Drivers and Process Effects on Forest Health}

While the taxonomic and phylogenetic structures of the forest determine its resistance and resilience, it is the characteristics of the drivers and processes that determine the impact of the disturbances. In FES, there are multiple levels of interacting biological entities, which underlie abiotic and anthropogenic processes and pressures like deforestation, $\mathrm{N}$ and $\mathrm{S}$ depositions, land-use, or climate change, which causes extreme events such as heavy precipitation, high temperatures or high ozone concentrations. All of these can affect $\mathrm{FH}$ in a different way at different spatial and temporal scales (Figure 1). It is not just the process or driver itself that is crucial for understanding the effect on FH, but also its characteristics that determine the levels (e.g., genetic, molecular or community), direction and reversibility of the effects. Important process characteristics for $\mathrm{FH}$ include the range, scope, duration, intensity, continuity, dominance, or overlap [47], which can alter the taxonomic, structural or functional diversity of FES on different spatio-temporal scales.

Land-use changes, deforestation or fire can alter forest traits in their overall complexity [11,48-51]. Furthermore, anthropogenic management can lead to a change in the spectrum of species and, thus, also in plant and plant community traits over space and time. When using RS for monitoring, we assume that these alterations are reflected in changes of the spectral response of RS signals. 
Garnier et al., [50] showed a direct relationship between plant characteristics (e.g., plant height and flowering phenology) as a response to land-use changes and disturbance regimes. The short and long-term dynamics resulting from disturbance in soil and vegetation can also lead to adaptations and often systematic, complex and sometimes even irreversible shifts in species compositions, configurations or distributions [52]. Moreover, deforestation, clearing, harvesting and disturbances often cause a complete and/or irreversible loss of entire forest communities and ecosystems, producing complex changes in the characteristics of the species or communities [50].

\subsection{Stress and Adaptation in FES}

From an evolutionary perspective, FES constitute the final stage of succession and thus the longest lived and largest plant species on land [39]. In fast-growing primary producer systems, interactions could be found between biodiversity and the functions, stability, vitality or health of ecosystems [39] whereas these are difficult to measure and understand in long lived FES. In their phylogenetic evolution, forests have developed adaptation strategies and reaction mechanisms to multiple-stress factors. Due to the long life of trees, there is still little knowledge about the length of time and the extent to which trees have to be impaired by stress factors in order to be able to observe visible changes in the branching geometry, necrobiotic processes, leaf production and tree functional processes [53]. Forest ecosystems can therefore appear to be stable over very long periods of time, when in reality they are irreversibly impaired. Lindenmayer and Likens [54] showed that species are not equally sensitive to environmental stress factors and changes. In addition to the species [55], a number of other factors can be crucial, including age [56] or the occupation of different ecological niches. Research work conducted after the nuclear reactor disaster from Chernobyl has provided important insights into the stress behaviour of different species. It was proven that intensive levels of exposure to radioactivity led to changes in trees, but the intensity and direction of the reaction depended on the tree species [57]. Furthermore, the ability of different tree species to adapt to expected climate change is still very much unclear [55].

At the same time, the effects of multiple stress factors on FH must be understood. It could be proven that a change in complex stress factors can have an influence in changing the respective system functions. Thus, when faced with changes from multiple stress factors, species and populations are able to adapt their respective functions or to take on complementary functions in the ecosystem [58]. To really understand FH in all of its complexity, the implementation of RS technologies as a global strategy for monitoring $\mathrm{FH}$ is imperative, which firstly entails understanding the basic principles, limitations and constraints of RS for monitoring FH.

\section{Quantifying Forest Health Using RS}

There is a wide range of remote sensing sensors, models and applications that deal with measuring, explaining and predicting FH [7,29,31,59-63]. Table 1 summarizes the RS applications, which can only be partially described in this paper. In addition to the sensors and platforms used, FH indicators are also categorized as indicators of taxonomic, functional or structural diversity of FES.

The ability to monitor FH indicators with RS data is dependent on the following factors: (i) the characteristics of forest traits and the shape, density and distribution of forest traits in space and time; (ii) the spatial, spectral, radiometric, angular and temporal resolutions of RS sensors or multi-sensor systems; (iii) the choice of the modelling technique (classification or biophysical/chemical variable estimation) and entity representation (pixel-based or (geographic) object-based); and (iv) how well the RS algorithm and its assumptions fit the RS data and the plant traits and trait variations in FES. 
Table 1. Spectral plant traits of forest health quantified by RS technologies.

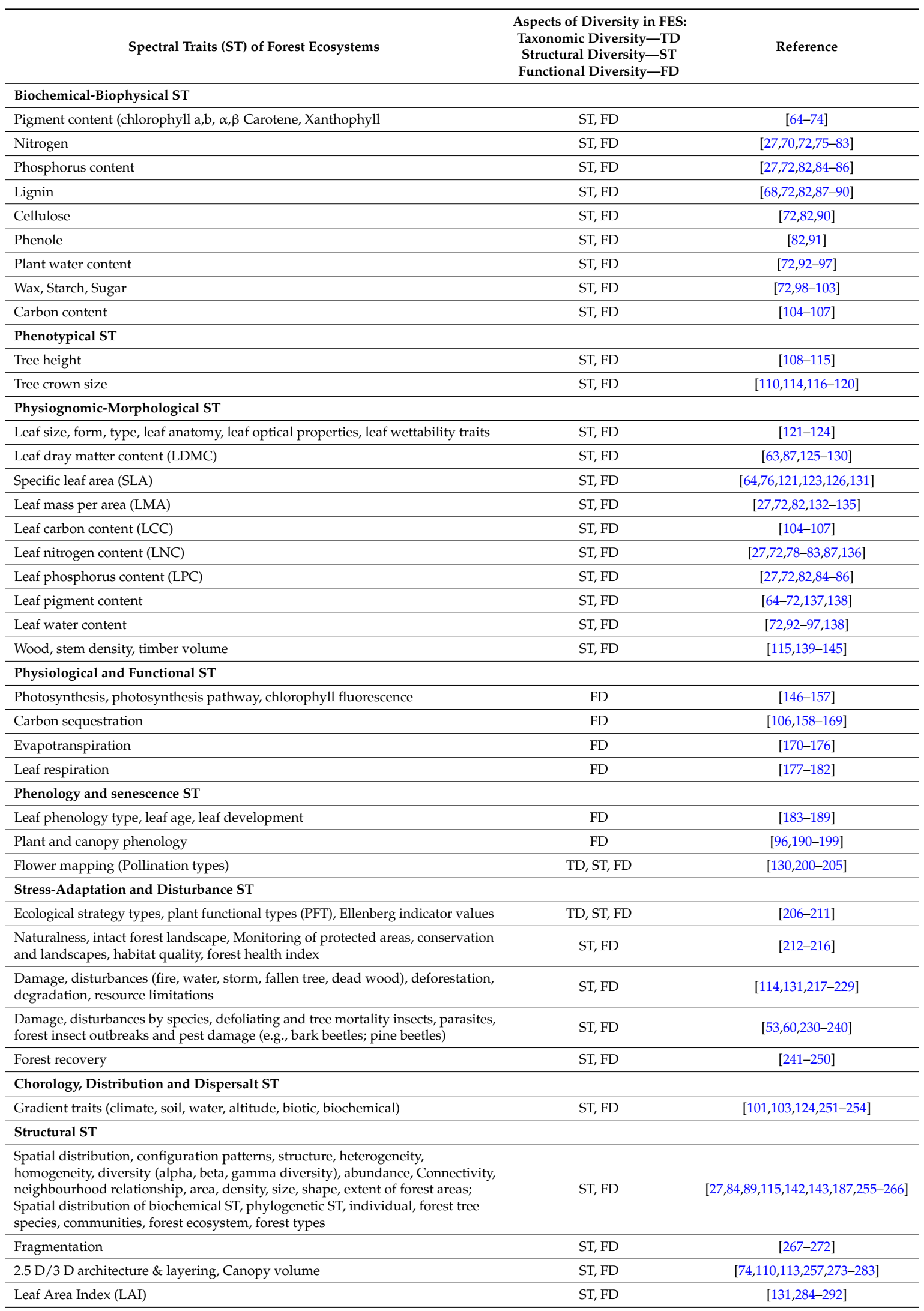


Table 1. Cont.

\begin{tabular}{|c|c|c|}
\hline Spectral Traits (ST) of Forest Ecosystems & $\begin{array}{l}\text { Aspects of Diversity in FES: } \\
\text { Taxonomic Diversity-TD } \\
\text { Structural Diversity-ST } \\
\text { Functional Diversity-FD }\end{array}$ & Reference \\
\hline Net Primary Production (NPP) & FD & {$[6,293-302]$} \\
\hline Fraction of Photosynthetically Active Radiation (fPAR) & FD & {$[287,292,303-309]$} \\
\hline Biomass & ST, FD & {$[143,167,255,298,310-316]$} \\
\hline Scaling traits & TD, ST, FD & {$[317,318]$} \\
\hline Phylogenetic information of traits & TD, ST, FD & {$[89,319]$} \\
\hline \multicolumn{3}{|l|}{ Additional Indicators of Forest Health } \\
\hline \multicolumn{3}{|l|}{ Animals } \\
\hline $\begin{array}{l}\text { Animal species-direct detection, GPS tracking } \\
\text { (e.g., birds, wildebeest, deer storks, cranes, gulls, geese, lynx, bear, deer) }\end{array}$ & TD & {$[46,320-332]$} \\
\hline $\begin{array}{l}\text { Modelling of animal and forest plant species behaviour } \\
\text { (e.g., birds, chimpanzee, bison, cattle, grizzly bear, wild dogs, deer, lions, forest } \\
\text { tree cover) }\end{array}$ & TD, ST, FD & {$[46,320-322,333-340]$} \\
\hline \multicolumn{3}{|l|}{ Forest Vegetation (Individual, Plant, Population, Community) } \\
\hline $\begin{array}{l}\text { Tree species discrimination, tropical forest types, dominant species, and mapping } \\
\text { of functional guilds }\end{array}$ & TD & {$[64,134,210,274,341-353]$} \\
\hline Invasive species & TD & {$[76,335,354-361]$} \\
\hline \multicolumn{3}{|l|}{ Shifts of Traits, Plants, Populations, Communities of FES } \\
\hline $\begin{array}{l}\text { Shifting biochemical traits } \\
\text { (photosynthesis respiration, plant productivity, phenology, growing } \\
\text { season length, variation in carbon dioxide exchange and carbon balance, } \\
\text { greening response) }\end{array}$ & ST, FD & {$[77,82,84,162,191,194,197,362,363]$} \\
\hline Shifts in plants, populations, communities & ST, FD & {$[364,365]$} \\
\hline Forest inventory indicators & ST, FD & [366-372] \\
\hline Tree age, forest age structure, forest stand age & ST, FD & {$[283,373-375]$} \\
\hline Deadwood & ST, FD & {$[131,224,376-378]$} \\
\hline Defoliation & ST, FD & [379-385] \\
\hline Drought and heat induced tree mortality, drought-stress & ST, FD & {$[92,173,386-390]$} \\
\hline $\begin{array}{l}\text { Forest monitoring, forest change } \\
\text { Land-use and land cover changes (LULC) }\end{array}$ & ST, FD & {$[62,131,314,391-408]$} \\
\hline
\end{tabular}

\subsection{Spectral Traits \& Spectral Trait Variation Paradigms for Quantifying Forest Health Using RS}

RS technology can only record entities of FH based on physical characteristics. This means that the reflectance and scattering properties in individuals, plants, communities, habitats and biomes are "based on principles of spectroscopy across the electromagnetic spectrum from visible to microwave bands" [137]. The use of RS technology with optical, thermal, active and passive RS to record indicators of FH follows a specific characteristic and is subject to specific parameters that significantly influence quality as well as reproducibility (Figures $2-4$ ).

Step 1: Remote sensors record the amount of electromagnetic radiance at the sensor in different wavebands and this radiance represents the traits of abiotic and biotic surfaces from which the radiance emanated. Biotic traits are biochemical, physiological, morphological, structural, phenological or functional characteristics of plants, populations or communities [46,409-411]. With the help of biotic traits, we are able to describe, explain and predict (1) why forest plants and communities "live where they do" [412]; and (2) how forest plants respond to different natural and anthropogenic processes, drivers, stress factors and resource limitations. Furthermore, traits form the only link between in-situ terrestrial forest monitoring approaches and RS approaches to quantify and understand indicators of $\mathrm{FH}$. 
Not all of the biotic traits which are basically used in in-situ species trait approaches $[410,413]$ can be detected by RS $[137,414]$. Therefore, traits that can be recorded using RS are in contrast to the in-situ species trait approaches, referred to as "Spectral Traits" (ST) and "Spectral Trait Variations" (STV) [46]. Traits that cannot be recorded using RS are referred to as "Non-Spectral Traits" (N-ST, Figures 2 and 3 ). N-ST are for example: (i) when the traits are underground or when they cannot be detected by a given sensor, such as forest undergrowth or roots (i.e., the type of mycorrhiza and rooting depth (Figure 3), seed size, seed longevity); or (ii) when current RS characteristics (the spatial, spectral, radiometric, angular or temporal resolution of the sensor or multi-sensor RS techniques) are not able to record the traits either directly or indirectly or have not been detected yet.

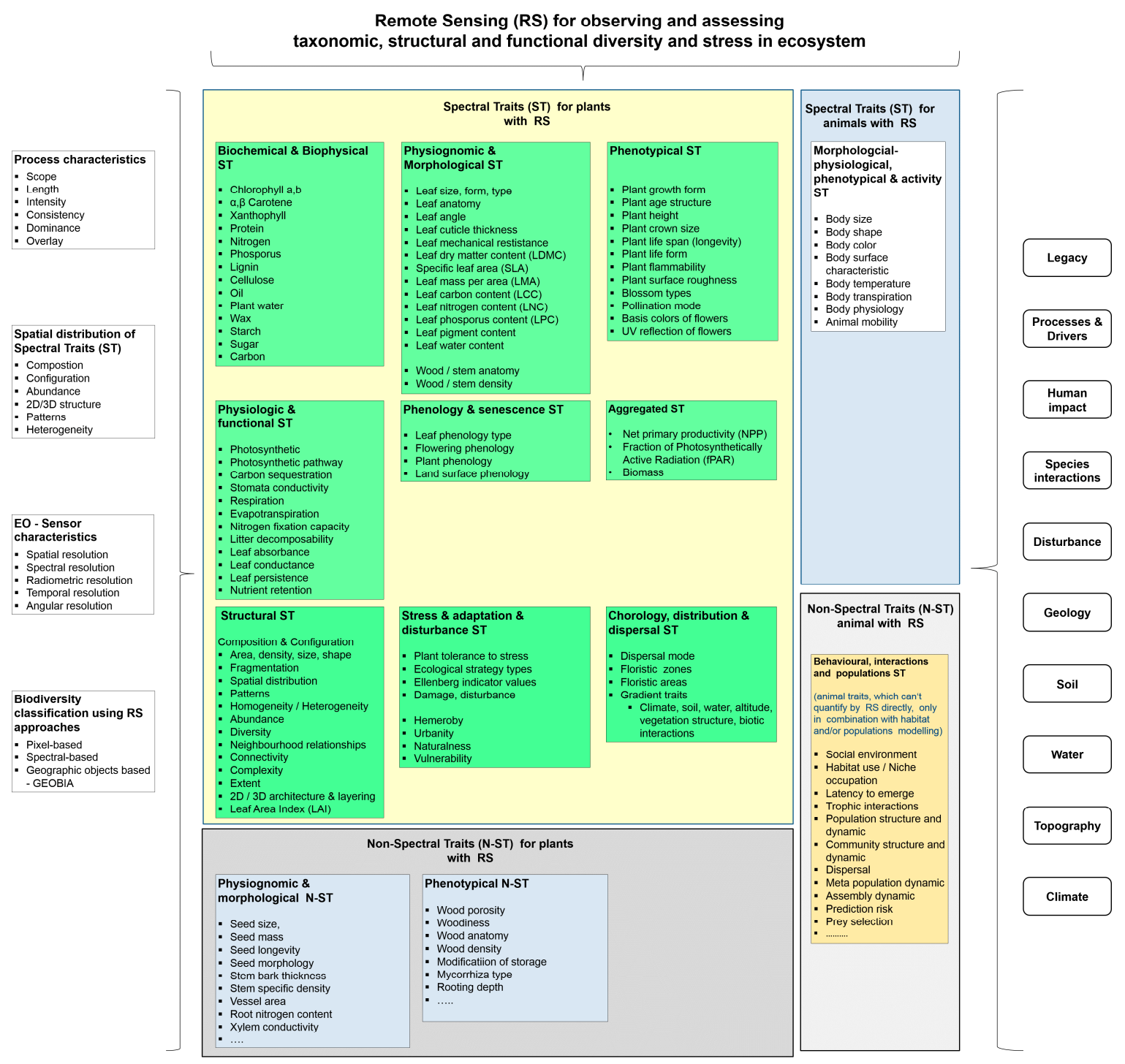

Figure 2. Spectral traits (ST) and Non-Spectral Traits observing and assessing taxonomic, structural and functional diversity and stress in ecosystems (modified after Lausch et al., [46]).

The definitions of Spectral Traits (ST), Non-Spectral Traits (N-ST) and Spectral Trait Variations (STV) for plants, populations and communities are as follows:

- ST are anatomical, morphological, biochemical, biophysical, physiological, structural, phenological or functional, etc. characteristics of plants, populations and communities that are influenced by phylogenetic, taxonomic, populations and communities characteristics, which can be directly or indirectly recorded using remote-sensing techniques in space. 
- N-ST are anatomical, morphological, biochemical, biophysical, physiological, structural, phenological or functional, etc. characteristics of plants, populations and communities that are influenced by phylogenetic, taxonomic, populations and communities characteristics, which cannot be directly or indirectly recorded using remote-sensing techniques in space.

- STV are changes to Spectral Traits (ST) in terms of physiology, senescence and phenology, but also caused by stress, disturbances and the resource limitations of plants, populations and communities, which can be directly or indirectly recorded by remote-sensing techniques in space and over time.

Step 2: In addition to recording and quantifying spectral traits using RS, taxonomically different species, populations, communities, habitats or biomes of FES (Figure 2) can be distinguished and monitored with RS if the biochemical, biophysical, morphometric, geometric, morphological or functional spectral traits among forest species or communities differ. If it is not possible to distinguish the spectral traits of the species or communities, then processes in seasonal changes of the species like senescence, phenology, physiological changes (gas exchange, photosynthetic activity or evapotranspiration, changes in 3D geometry), changes in biomass or seasonal changes in geometry can help with this distinction. Other supporting information may also aid this process, including the ability to identify traits against the soil background, the filling of specific ecological niches, resource constraints, specific adaptation mechanisms or ecological strategy types. The spatial composition and configuration such as the distribution, size, shape, aggregation and extent of forest spectral traits also play a crucial role when it comes to distinguishing among forest species.

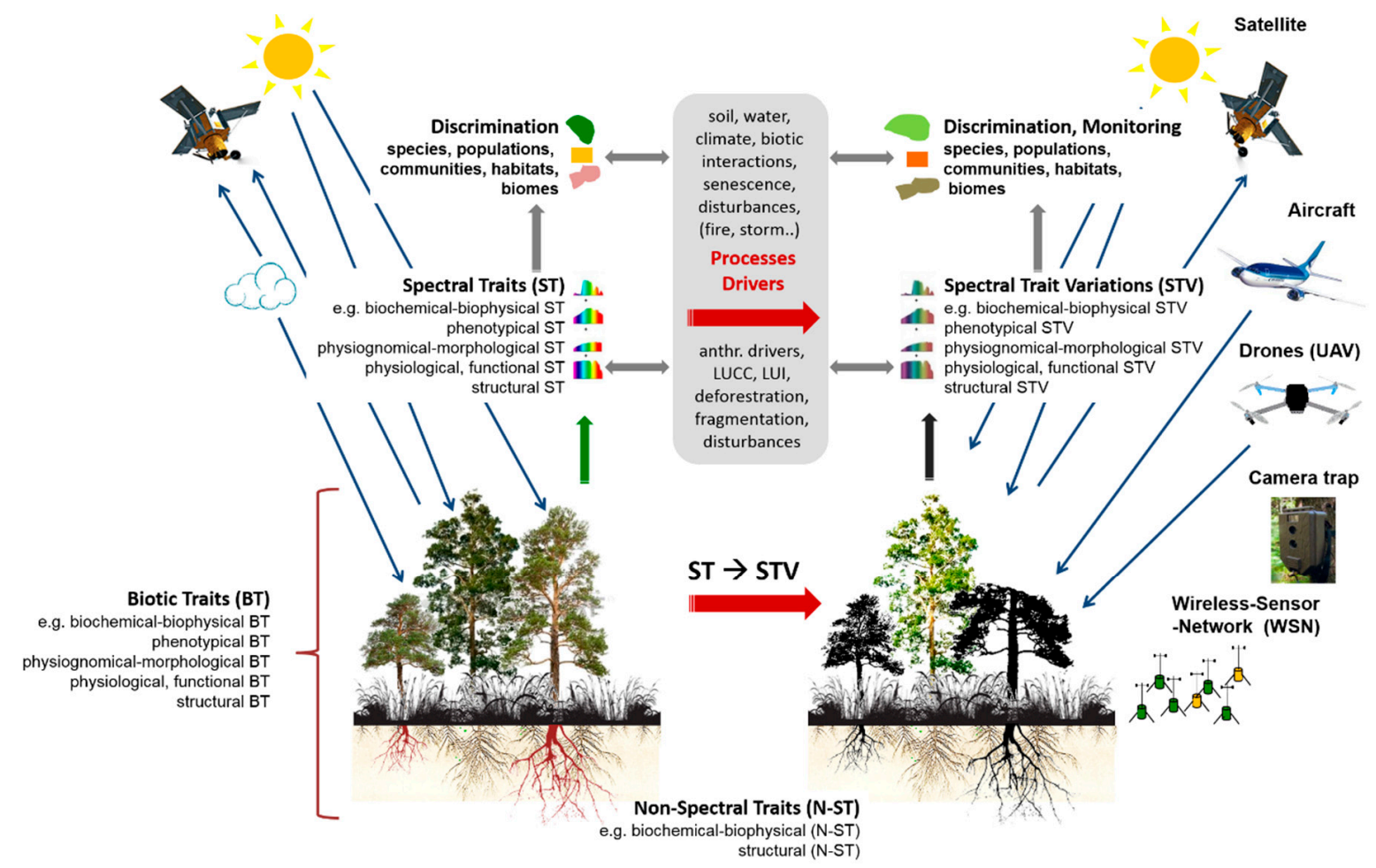

Figure 3. Quantifying spectral traits (ST) and spectral traits variations (STV) and their interactions with drivers and processes to record and monitor FH with RS (modified after Lausch et al., [46]). 


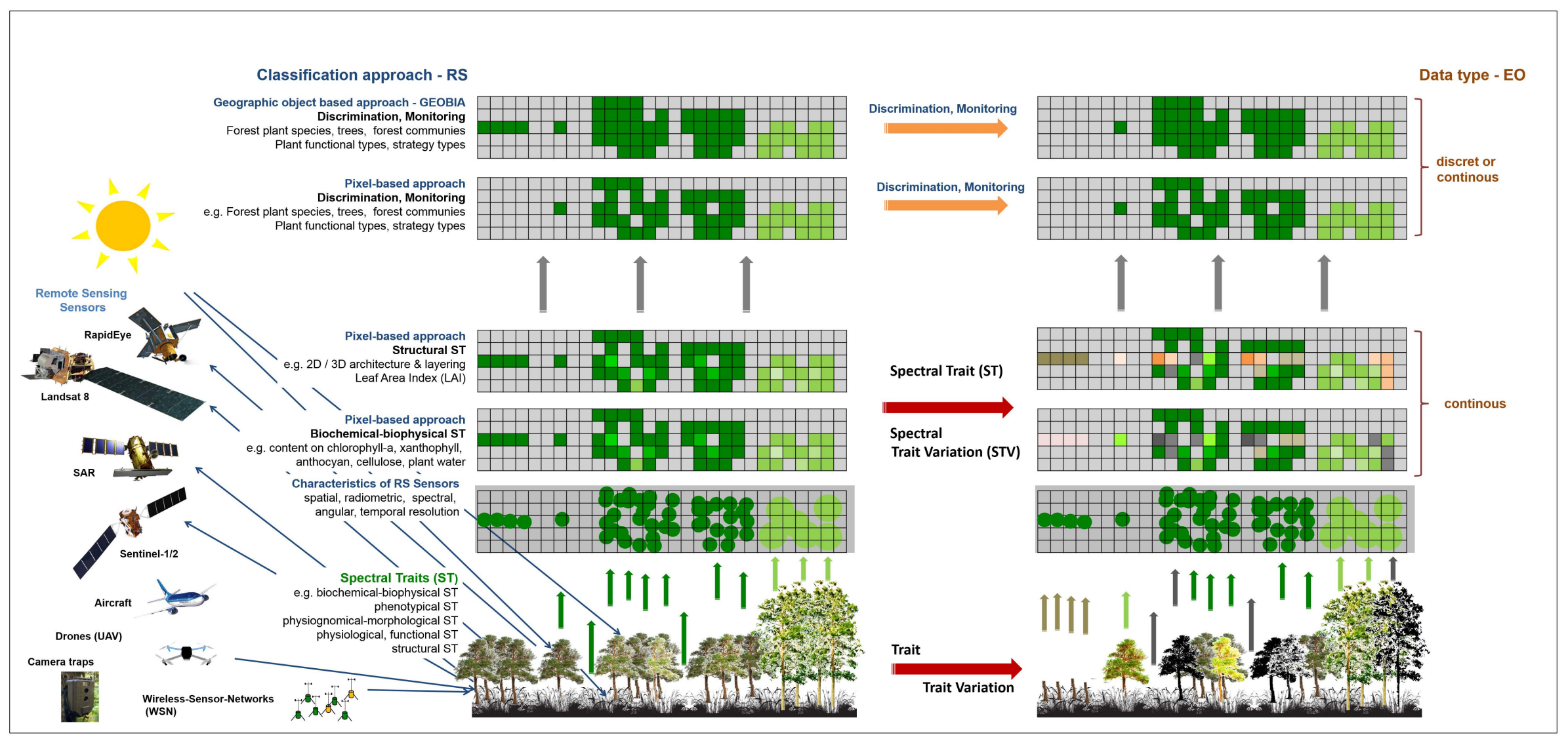

Figure 4. Remote sensing - a physically-based system, which records indicators of FH in two consecutive steps: Step 1 records spectral traits (ST) and spectral trait variations (STV); Step 2 distinguishes species, populations, communities and biomes of FES depending on the spatial, spectral, radiometric, angular and temporal resolution of the RS techniques, the distribution of ST/STV in space and their temporal changes, the choice of the modelling method (classification; biophysical/chemical parameter estimation) and the geographic data representation (pixel-based or (geographic) object-based) and the appropriateness of the RS algorithm and its assumptions for the given spectral traits. 


\subsection{Importance of Spatio-Temporal Patterns of ST/STV in FES}

In addition to the characteristics of forest traits, the spatial distribution, size, aggregation, shape and the extent over which given spectral traits are manifested play a crucial role in detecting ST/STV. A high density, small size or unfavorable shape of similar biochemical, morphological and structural forest traits makes it all the more difficult or even prevents the recording of forest traits using RS [46,78]. In contrast, high density forest vegetation with very diverse plant traits generates greater remotely-sensed spectral responses and favors the recording of indicators of $\mathrm{FH}$. At the same time, by deriving a spatio-temporal variability of traits with RS using the available knowledge of species diversity at a given location, conclusions can be drawn about the impact of external ecosystem processes. A high degree of species diversity does not always lead to an equally high diversity of traits. Moreover, a high diversity of traits—given low species diversity—can provide insight into adaptations or even disturbances in an ecosystem. The spatial distribution of individual plant and community ST/STV may only be evaluated in connection with specific sensor characteristics-the spatial, spectral, radiometric, temporal and directional resolution.

\subsection{Characteristics of RS Data for Quantifying FH}

RS data to record indicators of FH vary in their spatial, spectral, radiometric, temporal and directional resolution (Figures 2 and 4) and therefore in their ability to record forest ST/STV. Depending on the sensor platform, the spatial resolution may be millimeters (e.g., drone-based cameras), 0.5-2 m (airborne, hyperspectral sensors-AISA, HySPEX, APEX), 2-10 m (satellite sensors such as WorldView-2, RapidEye, Sentinel-2), 10-30 m (Spot, Landsat), and up to 250-1000 m or greater (MODIS and NOAA AVHRR). The spatial resolution, the characteristics and the density of forest ST/STV will determine the characteristics that are contained in one pixel. In this way, every pixel can contain a combined reflectivity of multiple characteristics of ST/STV [46].

Spectral resolution is also crucial for making qualitative distinctions among forest traits and taxonomic distinctions among forest species and communities. Narrowband hyperspectral RS sensors with a spectral range of 0.4-2.5 $\mu \mathrm{m}$ like the "Cubert UHD 185-Firefly" [415], the airborne hyperspectral system sensors HySpex, HyMAP, AISA or satellite-based hyperspectral sensor EnMAP (Environmental Mapping and Analysis Program, to be launched in 2018, Guanter et al., [416] are able to quantify many different biochemical and biophysical ST and STV in forest ecosystems $[7,64,65,77,84,152]$ (see also Figure 2). Furthermore, these sensors are able to taxonomically recognize more than 20-30 different tree species [343] compared to sensors with broad spectral bands such as Landsat, Spot, Aster, Sentinal-2 and RapidEye. The development of sensors with high spectral resolution $(0.3-3.0 \mu \mathrm{m}$, Fluorescence Explorer Satellite, FLEX, ESA, 2018, [152] allows for the detection of important eco-physiological process traits such as photosynthesis and solar-induced chlorophyll fluorescence for a better understanding of global photosynthetic activity, $\mathrm{CO}_{2}$ fluxes and budgets [21,152].

The temporal resolution of RS sensors is another decisive factor for improving the discrimination of species, populations, communities or forest types (see Chapter 4) as well as the quantification of ST/STV. Senescence, phenology, stress, disturbances and resource limitations are all factors that lead to changes in traits at very different time intervals. Therefore, it is essential to have sensors that can also record processes and STV at different temporal frequencies. Lausch et al., [21] extensively discuss the implementation of in-situ RS methods such as plant phenomics facilities and the Ecotron (controlled environment facility), spectral measurements from towers or terrestrial wireless sensor networks (WSN), where a monitoring of ST/STV of FH is carried out at high temporal frequencies. Moreover, spaceborne RS are developed or can be used with a high temporal resolution and revisit time such as TerraSAR-X (DLR and Airbus Space and Defence, 1-2 days), WorldView-2,3 (Ball Aerospace \& forest biomass, Technologies Corporation, fully commercial, 2009 and 2014, 1 day), EnMAP (Environmental Mapping and Analysis Program)/BMBF \& BMWi Germany, 2019, 4 days), RapidEye (PlanetLabs 2008, 1 day), Sentinel-1A /B two-satellite configuration/ESA (2014 and 2015, 2 days), 
Sentinel-2A /B two-satellite configuration/ESA (2015 and 2016, 5 days), Sentinel-3A/B two-satellite configuration/ESA (2016 and 2017, 4 days) [22].

Until today, only limited research has been conducted into the spatial, spectral or temporal resolution of such sensors for the assessment of ST/STV. Lausch et al., $[417,418]$ showed that for a given stable experimental design (the same sensor, time, recording frames and region) the spatial resolution is more important than the spectral resolution in discriminating the spatial heterogeneity in vegetation. Sensors with a low spatial resolution often have a higher temporal resolution (e.g., AVHRR, MODIS with 1-2 revisits/day). Sensors with high spatial and spectral resolution are generally limited in temporal resolution. However, these constraints are gradually being improved upon with the development of new sensor technologies (e.g., Sentinel 2-10 m, $20 \mathrm{~m}$, and $60 \mathrm{~m}$ spatial resolution in the VNIR to SWIR spectral range, 5-day revisit time). In addition, more approaches are being developed that enable data merging from sensors with different spatial, spectral and temporal resolutions for the purpose of extracting information relevant to different indicators of $\mathrm{FH}$ [21].

Detecting indicators of forest health is not only based on spatial, spectral and temporal resolutions. Due to different growth forms, geometry, tree height and structural diversity as well as the heterogeneity of the tree stands such as tree density, crown shape and leaf orientation, diversity of tree height, the angular (or directional) resolution plays a major role [419-421]. According to Koukal [419], "the directional domain of reflectance is mostly ignored, although the variation of reflectance properties with the sun and view angle (anisotropy) of forest canopies is substantial". If the anisotropy of reflectance is not taken into account in forest health models, it will lead to noise in the spectral signatures and thus to errors in the quantification and monitoring of ST/STV with RS [419].

\section{How Can Remote Sensing Contribute to the Quantification of Stress in FES?}

The crucial question that we need to ask is why are RS techniques suitable for detecting and monitoring stress, distribution or resource limitations for assessing FH? The following points help us to answer this question:

1. Taxonomic and phylogenetic characteristics of forest plant species as well as natural and anthropogenic processes and drivers affect biotic traits or lead to trait variations in plants, populations, communities, habitats or biomes of FES in space and time [50].

2. Plant traits and plant trait variations are therefore proxies of the state, abiotic and biotic limitations, ecological interactions, processes and pressures which affect forest plant species and communities [46,206,208].

3. Drivers, processes and stress can manifest in the molecular, genetic, epigenetic, biochemical, biophysical or morphological-structural changes of traits [422-424] which can lead to irreversible changes in taxonomic, structural and functional diversity in FES. These changes can be measured by spectral traits and spectral trait variations (Figure 3).

4. RS is a physically-based system that can only directly or indirectly record the spectral traits and spectral trait variations in plants, communities or biomes [137,414] (Figure 4).

5. Spectral signatures, patterns and heterogeneity recorded by remote-sensing techniques are therefore proxies of spectral traits and spectral trait variations and thus the results of their state and changes through biotic and abiotic source limitations and interactions and lastly the results of drivers, processes and pressures on FH [46].

Therefore, the plant trait approach allows a new way of understanding some fundamental questions about forest diversity. Traits and trait variations help us to understand, "why organisms live where they do and how they will respond to environmental change" [412] and interact with different stressors, disturbances, resource limitations and drivers. Traits and trait variations can therefore be described as filters for status, changes, stress, disturbances or resource limitations to taxonomic, structural and functional diversity of FES and FH [423,425] (Figures 5 and 6). 


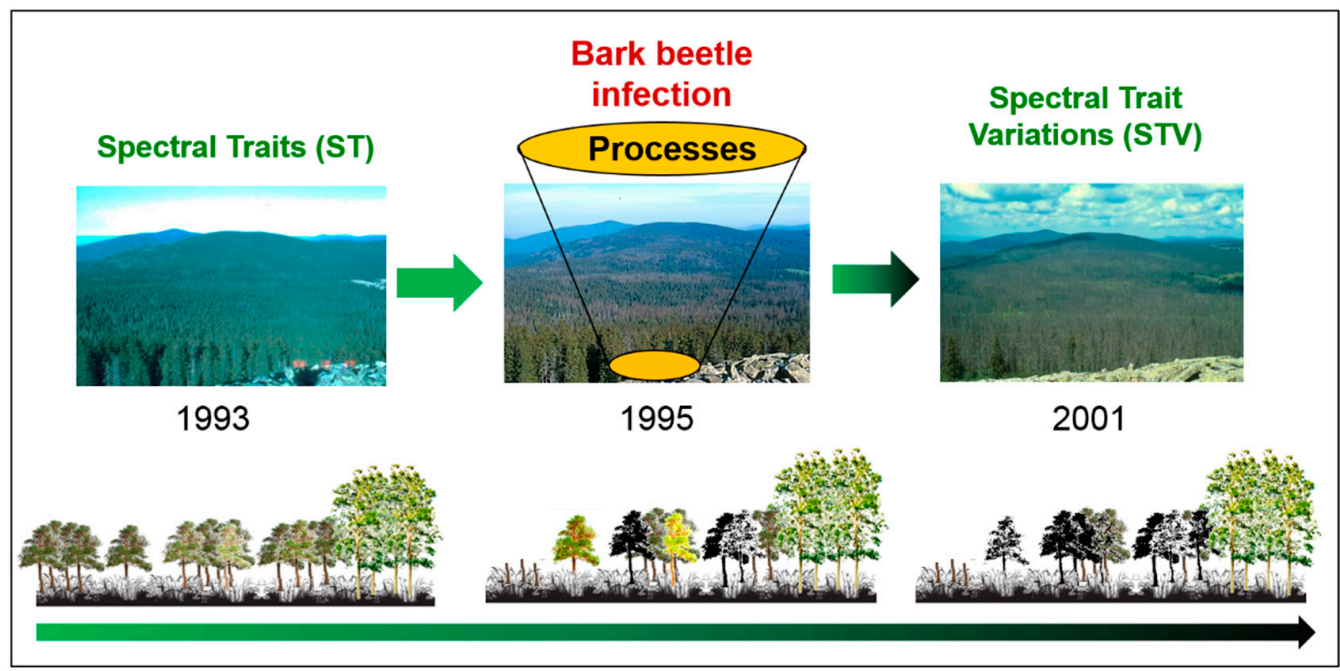

Figure 5. Changes to forest traits caused by different processes, drivers and stressors which can be observed using remote-sensing technologies. Photos by Marco Heurich.

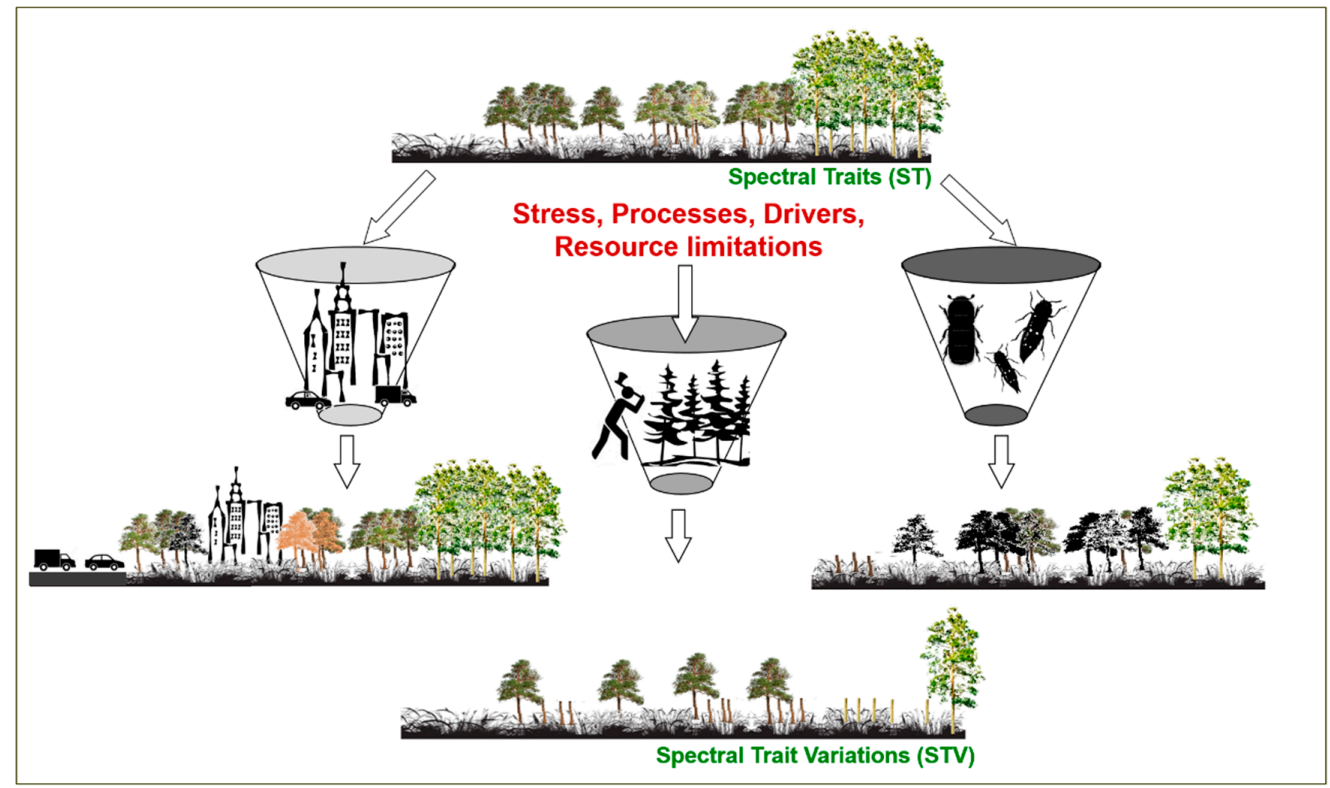

Figure 6. Different stress factors, processes, drivers or resource limitations result in changes of spectral traits (ST) to spectral trait variations (STV) in forest ecosystems.

Not every change of $\mathrm{FH}$, however, can be specifically assigned to a particular trait variation. For example, bark beetle infections of Picea abies lead to a reduction of chlorophyll and subsequently to a reduction of photosynthetic activity. These symptoms can also be caused by soil limitations or acid rain. Furthermore, reduction of chlorophyll concentration is also a process of senescence in forest plant species such as deciduous trees. Only with the integration of information on process characteristics such as process duration or intensity is it possible to differentiate the processes and drivers based on ST/STV.

ST/STV of FH that can be observed using different RS technologies can be:

- Alterations to biochemical spectral traits such as cellulose, nitrogen and lignin [128,426], or changes in the composition and configuration of photosynthetically-active pigments $n$ 
leaves-chlorophyll, xanthophyll, $\alpha, \beta$ carotene, xanthophyll [7,64,76,99,427]. Changes to the intra- and extra-cellular water content or the percentage water in plants [428-430].

- Variations in the physiological and functional spectral traits such as photosynthesis activity and efficiency photosynthetic pathways, carbon sequestration, plant respiration or nutrient retention [153,431,432].

- Changes and shifts in bio-functional processes (evapotranspiration, energy balance in plants and mechanisms such as the phenotypical plasticity and phenotypic shifts of plants $[82,84,162,170,194]$.

- Changes in 2D or 3D structural spectral traits such as leaf arrangement and geometry, tree height or area, density, size, the shape of forest patches as well as fragmentation, complexity, homogeneity or the diversity of species or communities. Furthermore, forest canopy height, forest extent as well as the vertical and horizontal vegetation structure of forests [258,433].

- Alterations in the stress levels and adaptation or the disturbance of spectral traits such as the protective mechanisms of leaf hair and cuticles.

- Plant functional types (PFTs) or plant strategy types $[206,208,209]$ or the Ellenberg indicator plant species [207,211].

- Turnover in species composition like spatial heterogeneity and dissimilarity $[258,349,434]$ or spatial structure and distribution of species composition, tree community turnover [435-437].

- Spectral traits of productivity and diversity and disturbances [241,437].

For more examples, see Table 1 and [21,46].

\section{Monitoring Stress in Taxonomic, Structural and Functional FES Diversity to Assess FH}

Stress effects and changes to taxonomic, structural and functional diversity are good indicators of the stability, resilience or stress and instability of FES. The real question, however, is the extent to which RS is able to detect and monitor taxonomic, structural and functional diversity as well as its changes.

There are many different approaches for quantifying, predicting and modeling species distributions using RS sensors on different spatial scales: (i) the direct identification or detection of forest species; (ii) the detection and quantification of habitats or forest ecosystem types; and (iii) the use of proxy variables for predictive species distribution models (SDMs) [46].

\subsection{Direct Monitoring of Stress on Animal Species in FES with RS}

Animals are constantly subjected to pressure from predators, environmental changes, stress and disturbances [324]. Stress leads to changes in species distributions, species losses, changes in habitat patterns and fragmentation as well as the different morphological adaptation mechanisms of animal species. It has long been recognised, for example, that birds are extremely sensitive to the intensive use of pesticides such as DDT in the landscape [438]. Similarly, it was discovered that the dramatic decline in bee populations as a reaction to pesticides and land use changes has led to a loss of pollination, one of the most important ecosystem functions. There exist many studies examining the effect of forest fragmentation and forest patch size on the physiological stress response in forest animals and animal communities [439-441]. Therefore, animals are crucial bio-indicators of disturbances, stress and environmental changes.

Recording animal species with RS is only possible under certain circumstances. Comprehensive reviews on detecting animals using RS techniques can be found in [46,320,321]. Factors that are important if animal species are to be directly recorded using RS are: (i) their characteristic traits such as body size, shape, colour, surface characteristics, movement, sounds or body temperature; (ii) the characteristics of the RS sensors; and (iii) the RS platforms that are used (in-situ RS platforms such as camera traps, UAV, airborne, spaceborne RS platforms, see Figure 2).

The GPS lifetime tracking of animal species in FES has proven to be successful (e.g., for lynx, wild boar, red deer, storks, cranes, gulls, geese, brown bears, chimpanzee) in recording movement 
and behaviour and helps to gain a better understanding of population effects from environmental changes in FES [323,325,442-444]. The most state-of-the-art lifetime tracking technology will soon enable smaller animals such as bees or beetles to carry transmitters. In addition to GPS information, multi-sensors will also be increasingly implemented to record images and videos, and to monitor numerous physiological parameters such as body temperature, physiological stress indicators, but also activity patterns, habitat characteristics, and mating and feeding behaviour. All transmitter information will be recorded in the future over the "satellite-based ICARUS system, which is to be installed by German and Russian space agencies in 2017" [324]. Data will be stored centrally in the movement database [323,445].

Recently, the implementation of camera traps has increased in FES to estimate population sizes, to understand behavioural and activity patterns and under some circumstances to record the habitat of animals [326,334]. Low cost camera traps with high battery lifetimes and memory capacity integrate thermal and movement sensors as well as RGB-photo and video technology and can record animals in FES [326,327,334,446]. Thermal cameras and multi-sensor combinations with optical sensors and LiDAR on UAV- and airborne platforms have been used to record wild animal species such as the white-tailed deer [331,447,448]. In this instance, the body temperature of the animals is used, as it differs considerably from the surrounding environment (especially at night, at dusk or dawn). Direct classification of FES animals have been conducted using satellite RS techniques such as RapidEye or Worldview-2 for a number of animal species such as deer, wildebeest or birds [320,449], and UAV technology is becoming more commonly applied in recording wild animal species [448]. However, the success of UAV and satellite technologies for recording wild animals within forest has been found to be very limited.

\subsection{Modelling Stress and Disturbances in Species Distributions and Animal Behaviour in FES}

The quantification of species-environment relationships based on species distribution models (SDMs) is an important methodical approach [450,451] to monitor and understand the stress or resource limitations on forest species. RS data on different platforms, i.e., camera traps, drones, airand spaceborne data, are able to map and quantify biotic and abiotic land surface traits. In terms of SDM modelling, RS can also be used to record a number of abiotic environmental variables such as topographic- [452] soil- [453,454] and climate conditions [455,456], their status, alterations and, therefore, also their impacts on animal species in FES. SDM based on RS approaches will "shape the next generation" of SDMs [335]. With RS it is not just the status quo or the long-term monitoring and changes in FES that can be examined, but also significant short-term changes to the taxonomic, structural and functional traits of FES from the regional to the global scale, which is not possible with in-situ recording of animal behaviour.

The SDM approach is very different from the detection and quantification of the forest habitat quantification approach. The objective of SDM is "to predict the probabilities of species occurrence as the single target variable " [457]. The opening of LandSat RS portals as well as an increasingly more common data policy of freely available RS data and data products such as the Copernicus missions (Sentinel 1-5) or the hyperspectral (EnMAP) satellite missions makes extensive spatio-temporal data available to SDM. Determining the growth period [194] deriving global NDVI trends [458], recording shifts in biochemical traits [82,84,162,194], recording changes in land-use [459], land-use intensity [460] or long-term deforestation dynamics as well as quantifying structural forest characteristics like fragmentation, spatial distribution, structure, heterogeneity or homogeneity configuration of forest patterns are all factors that provide us with crucial information [143,257,259,271]. Deblauwe et al., [461] used remotely-sensed temperatures and precipitation data derived from RS-data to improve species distribution modelling in tropical forest areas. Franklin et al., [462] analysed global change and terrestrial plant community dynamics using remote-sensing based monitoring of vegetation changes. Furthermore, Boiffin et al., [463] used SDM to determine the migration rate and the species occurrence of Douglas-fir and climate predictors in North America. Furthermore, Coops et al., [337] used RS 
land cover and RS data to estimate tree species migration. The modelling of animal behaviour is a widespread method for modelling animal distributions (e.g., birds, deer, lynx, bears, foxes, wolves, moose or bison), [320,330,338,464,465]. High-resolution RS data were also used, for example, in an unmanned aerial vehicle (UAV) and RS data for monitoring and discrimination of forest and tree species in the context of assessing the suitability of chimpanzee habitats in Tanzania as a basis for making critical decisions about species conservation [336,466]. An extensive overview of recording terrestrial animals using remote sensing is provided by [46,320-322].

A crucial application of RS is to record changing biochemical forest traits such as chlorophyll and water content or a reduction in the photosynthetic activity in trees. High resolution temporal as well as spectral RS data such as Sentinel-2, WorldView-2 Data or hyperspectral RS sensors such as APEX, AVIRIS, HySpex, AISA and the upcoming spaceborne hyperspectral sensor EnMAP are used to record disturbances in the vitality of forests resulting from climate change, resource limitations and disturbances or damaging insects such as bark beetles or pine beetles, [53,237,240,467,468] as well as fungal infestations (such as the recent infestation of ash trees). In this context, the investigations on early detection of Bark Beetle infestations of spruce trees are particularly noteworthy. In this case, non-infested trees are separated from infested ones that are still not suffering from "green-attack" from already highly infested or dead trees due to their spectral reflectance using RS data. Immitzer \& Atzberger [240], for example, used WorldView-2 data for the early detection of Bark Beetle infestation in Norway Spruce (Picea abies, L.). The classes that were investigated, namely: "healthy", "infested, but no visible change in colour" and "dead" were separated with a total accuracy of around 75\%. Lausch et al., [53] on the other hand used hyperspectral HyMAP remote-sensing data with a spatial resolution of $4 \mathrm{~m}$. In spite of the high spectral resolution of the RS data with a spatial resolution of $4 \mathrm{~m}$, only a total accuracy of $64 \%$ was obtained. This example shows that the high spatial resolution $(1.8 \mathrm{~m})$ of the multispectral WorldView-2 data can lead to better results than the high resolution hyperspectral RS data, if the multi-spectral RS data contain spectral channel information that are decisive for classification. Similar conclusions are drawn by Lausch et al., [425] when comparing spatial vs. spectral resolution from RS data.

\subsection{Monitoring Stress on Vegetation in FES with RS}

Tree species richness and diversity are key parameters for describing the status, stability and the resilience of FES [341]. Numerous studies have mentioned the potential of RS technologies to record tree species taxonomy, richness and diversity [341-345]. As already described in detail in Chapter 3.1, the discrimination and monitoring of different taxa in forest plant species with RS is only possible when tree species can be differentiated from one another by their ST/STV (biochemical \& biophysical ST, physiognomic \& morphological ST or phenotypical ST, see Figure 2). Broadband RS sensors record less ST/STV than narrowband hyperspectral. Therefore, the forest tree species discrimination for broadband RS sensors such as Landsat, Spot, RapidEye, Worldview-2 and QuickBird is possible, but not as successful [344-348,352] as narrowband hyperspectral RS data [64,341-343,349]. Immitzer et al., [344] used very high spatial resolution 8-band WordView-2 Satellite Data for classifying 10 tree species with an overall accuracy of around $82 \%$ (eight bands, object-based). Magnard et al., [353] used SAR interferometry data as an alternative to airborne laser scanning (ALS) or photogrammetry-based RS for discriminating various tree species. By implementing multi-sensor approaches (optical, thermal, RADAR, LiDAR) as well as multi-temporal approaches, the number and type of ST/STV is increased, whereby a greater number of tree species can be differentiated. In this way, Elatawneh [350] were able to improve the discrimination for forest tree species by including multi-temporal phenological stages. Hill et al., [351] also used time-series multi-spectral data for the discrimination of tree species in temperate deciduous forest, whereas Neyret et al., [134] integrated $\mathrm{ST}$ indicators such as the variation of leaf mass per area to investigate dominant species across two contrasting tropical gradients in the context of community assemblages. Pierce et al., [210] used the leaf economics and size traits of CSR plant functional types to classify woody and herbaceous vascular 
plants. Various authors have also used multi-sensor approaches whereby the fusion of optical, RADAR, thermal and LiDAR data [31,469] extends the spectrum of recordable ST/STV, which ultimately leads to an improved discrimination of different tree species [21].

Invasive species: Various studies have shown that invasive plant species in FES can be mapped using RS techniques [355-358]. Asner and Martin [76] found that the biochemistry of invasive species is very different compared to that of native species. The ST/STV are therefore crucial indicators of the spectral discrimination of invasive species [335]. Asner and Martin [76] used the biochemical and biophysical ST of leaves, while Schneider and Fernando [359] used plant pigments and leaf coloration for successful mapping. Blumenthal et al., [360] integrated structural ST in addition to purely biochemical ST or indicators of structural homogeneity, like those that emerge from the specific arrangement of monocultures [470]. Somers and Asner [356], on the other hand, used multi-temporal Hyperion spaceborne imaging spectroscopy for invasive species mapping in Hawaiian rainforests. Apart from spectral biochemical, morphological and texture traits, other plant traits have also been used for species distinctions such as seasonality and phenology [357,361]. In addition to recording tree species taxonomy and distribution, the monitoring of forest populations and forest community structures [471] or forest types is also possible using RS, although it is also subject to the same constraints as for the discrimination of tree species. Ioki et al., [472] assessed the similarity between tree community compositions in a tropical rainforest using airborne LiDAR RS data, whereas Laurin et al., [436] recorded tropical forest types, dominant species, and functional guilds in FES by using hyperspectral and simulated multispectral Sentinel-2 data.

Plant functional types and plant strategy types: Environmental stress is a major factor, influencing plant traits and trait combinations [473,474]. Recurring combinations of structural, physiological or phenological traits are used to group plant species into Plant Functional Types (PFTs) $[48,206,475]$. PFTs are therefore important indicators of resource limitations or various stressors on FES, which can be measured using RS technologies [137]. The most important examples of PFTs are the CSR (Competitive, Ruderal, Stress tolerant) strategy types by [476], where plant traits change depending on their stressors and disturbance regimes. According to this system, community composition in FES is established from ruderal plants, competitive plants, and stress-tolerant plants. Plant traits such as the dry matter content, the canopy height, the onset of flowering, the flowering period, lateral spread, specific leaf area and leaf dry weight are all crucial factors for the position and mapping of plant species in the CSR trait space [206,208,209,477].

Land Use Land Cover (LULC) in forests can cause changes in the taxonomic, structural and functional diversity. Changes in LULC influence forest plant and community traits, leading to trait variations in forest ecosystems in their entire complexity [11,48,50,51] . For example, different forest management strategies are characterised by specific ST/STV. Pristine forests display a heterogeneous ST/STV in space and over time due to different forest tree species, different traits in growth forms, age, geometry or phenology and senescence compared to the relatively homogenous ST/STV in single species forest stands. Garnier et al., [50] were able to prove a direct relationship between plant traits (regeneration traits such as reproductive plant height and flowering phenology) as a response to land-use changes and disturbance regimes. Crucial changes to forest traits can be measured by spatial-temporal analyses of forest heterogeneity patterns [258], 3D distribution of forest canopy species patches [257], forest fragmentation [267-271], mapping of forest structures [259], or estimating forest area and forest biomass with TanDEM-X and RapidEye RS Data [143]. For more examples, see Table 1.

Monitoring forest cover changes or forest area dynamic on the local to the global scale has for some time now been extensively and successfully conducted using RS [62,314,402-407] helped along by open access and forward-thinking data policies with free use and storage in databases and archives from different RS data and data products [32,33,478] Furthermore, global environmental programs such as REDD+ (Reducing Emissions from forest Degradation and Deforestation) have been developed and require intensive forest cover monitoring. In addition to multi-sensor RS approaches 
with various RS sensors [401], multi-temporal RS have frequently been employed for LULC monitoring (for an extensive discussion see [22,46].

There are numerous remote-sensing data products and methods for the different types of RS data, which help us to use data for monitoring forest stress, disturbance and FH in a pre-processed and standardized way. These include the LandSat change detection products (CCDC), which integrate data from a 40-year monitoring period [399,400]. Furthermore, LandTrend (Landsat Detection of Trends in Disturbance and Recovery, [479]) is a trajectory-based land cover change detection method [480] which analyses time-series of Landsat RS data at once. The LandTrend algorithms can be used to analyse, monitor and describe sequences of disturbances and regrowth in FES. Comprehensive analyses of FH have been conducted based on LandTrend and LandSat Time Series (LTS) [392-396]. Comprehensive information and reviews of remote-sensing change detection and ecological monitoring can be found in [397,398].

Functional and structural stress: RS approaches are crucial for assessing the structure and functioning of FES [20,137]. This is based on functional traits sharing similar functions and showing similar effects and responses to environmental stressors, disturbances or resource limitations [48,413]. Here, the ST/STV paradigm helps to understand the effects of stress on functional diversity such as interactions between the absorbed radiation (APAR) and plant productivity (net primary production, NPP), [481], the relationship between biodiversity and carbon stocks [482] or interactions between canopy structure, canopy nitrogen and canopy near-infrared (near-IR) reflectance detected by RS [483]. Moreover, FES are crucial carbon pools and, therefore, important ecosystems in the global carbon cycle. Changes of carbon stocks are observed and monitored extensively using RS technologies [105,482,484-486]. Similarly, canopy foliar N distribution in FES [83], the global variability in leaf respiration in relation to plant functional types, leaf traits and the climate [487], the assessment of forest biomass [488], or the loss of canopy water in FES [389] or the shifting distributions of chemical traits in forest [82] are all monitored using RS. Furthermore, the biochemical, structural and functional characteristics of ST/STV such as photosynthetic pathways, pigment and nitrogen content, 2/3 D plant/canopy vegetation height, or leaf phenology are crucial for assessing ecosystem functions and ecosystem services such as photosynthetic activities, primary production, gas exchange and climate regulation [414].

In addition to monitoring stress on functional diversity, it is also possible to monitor changes to structural diversity in FES using RS. This ranges from analysing the composition, configuration and distribution of phylogenetic structures [89] to molecular biochemical structures and patterns in plants [21,489,490] to 2/3 D individual geometry and structure [491-493], populations and community structures $[349,435,436]$ and the recording of patterns and fragmentation in FES [494]. Further examples of monitoring stress and changes to the functional and structural diversity can also be recorded very well using RS. For an extensive list of other examples, see [19-21,46,137,219].

In the field of investigations on vegetation stress, rapid advances are currently taking place in the development of new RS technologies. For example, plant photosynthesis conditions and their changes are crucial for modelling carbon fluxes and water exchanges in soil-landscape-atmosphere modelling. However, the spatio-temporal variation of photosynthesis activity of the canopy vegetation shows great variations in seasonal, diurnal and spatial patterns but cannot be predicted sufficiently with conventional RS techniques [153,495]. At the same time, forecasts on stress and shifts in the photosynthesis system are currently only indirectly possible through plant traits of greenness and the amount of chlorophyll. The development of sensors with a high spectral resolution $(0.3-3.0 \mu \mathrm{m}$, Fluorescence Explorer Satellite, FLEX, ESA, 2018, [152] means that it is now possible for the first time to directly measure functional plant traits such as the solar-induced chlorophyll fluorescence signal as an indicator of photosynthesis conditions and efficiency in order to make better estimates of global photosynthetic activity, $\mathrm{CO}_{2}$ fluxes and budgets [152-155,496].

Furthermore, the new airborne instrument HyPlant was developed to monitor vegetation over a spectral range of 380-2500 $\mathrm{nm}$ (spectral resolution of 3-10 nm) and an additional segment, to monitor 
the chlorophyll fluorescence over the spectral region from 670 to $780 \mathrm{~nm}$ (with a high spectral resolution of $0.25 \mathrm{~nm}$ ) as an indicator of photosynthesis conditions as well as to effectively detect stress and shifts in photosynthesis for vegetation [153]. Research at plant phenomics facilities [497] and the controlled environmental facility Ecotron [498,499] have made tremendous contributions towards the development of FLEX and HyPlant sensors [21].

In the future, RS sensors will be enhanced with high spectral, spatial and temporal resolution, on the one hand, such as HyPlant, FLEX, EnMAP as well as the future hyperspectral/thermals combination HyspIRI (to be launched in 2020, [500]) or the multispectral/hyperspectral RS combination HISIRI (Hyperspectral Imager Suite) and used in combination with other RS techniques (multi-sensor) such as RADAR or thermal radiometer (ECOsystem Spaceborne Thermal Radiometer Experiment on Space Station (ECOSTRESS, scheduled for 2017, [501]), in order to increase the number of spectral traits and spectral trait variations of forest vegetation that can be recorded and to obtain better predictions about the resilience, stability or stress and instability of FES [502,503].

\section{Conclusions}

FH is characterized by a high degree of stability, elasticity and resistance to stress, disturbances and resource limitations, when a scale- and FES-dependent taxonomic, phylogenetic, structural as well as functional diversity is maintained or at least restored after the impacts of stress. To monitor and understand the entire complexity of $\mathrm{FH}$, its driving forces and mechanisms, it is imperative to establish a cost-effective, extensive, repeatable and standardised FH monitoring program. Remote sensing is a key technology in these programs.

RS as a physically-based system records spectral traits as well as spectral trait variations in FES. Since ST and STV are proxies for stress, disturbances and resource limitations can be found on all spatio-temporal scales. The ST/STV approach with RS techniques is suitable for monitoring the status and changes of the taxonomic, structural and functional diversity in FES. Structural as well as functional disturbances to FH can be effectively recorded with RS techniques using the ST/STV approach, whereas the ability to monitor stress in the taxonomic and phylogenetic diversity of forest animal and plant species is limited with RS techniques.

Extensive investigations have established the constraints under which the taxonomic, structural and functional monitoring of forest species, populations and communities is possible with RS. In this way, the characteristics ST and STV, the shape, density and distribution of ST/STV, different sensor characteristics, the choice of the classification method and the use of different RS algorithms all influence accuracy in the monitoring of indicators of $\mathrm{FH}$.

$\mathrm{RS}$ is suitable for recording disturbance processes to FH (from short-term to long-term processes), which is not (or only insufficiently) possible with terrestrial FH surveys. In contrast to RS, however, terrestrial FH surveys can record precise taxonomic and phylogenetic information about forest species, making crucial information on phylogeny, tolerances, resilience and threshold values available, which are important input variables for calibrating RS data as well as understanding stress and spectral response processes.

It should therefore be the goal of future research on $\mathrm{FH}$ to link terrestrial and RS-based approaches [20,46]. In doing so the ST/STV paradigm might be used as an interface between both information sources. Future research on RS technologies should focus on making previously non-recordable yet relevant non-spectral traits (N-ST) recordable in the future through new technologies and multi-sensor approaches.

Since numerous constraints influence the ability to ascertain FH indicators using RS, the standardised recording of FH indicators using terrestrial and RS-based approaches will be one of the greatest challenges in the future if we are to gain a better understanding of $\mathrm{FH}$ and forest ecosystems. Furthermore, compared to the Essential Biodiversity Variables (EBV) for FH, the "Essential Forest Health Variables" (EFHV) also need to be clearly defined, so that comparable indicators of FH can be monitored on all spatio-temporal scales. 
Acknowledgments: We particularly thank the researchers for the Hyperspectral Equipment of the Helmholtz Centre for Environmental Research-UFZ and TERENO funded by the Helmholtz Association and the Federal Ministry of Education and Research. The authors also thank the reviewers for their very valuable comments and recommendations.

Author Contributions: A.L. was responsible for the main part of this review analysis, writing and production of the figures. M.H. and P.M. provided extensive contributions on recording terrestrial forest health as well as substantial input about methods used for implementing sensors in the context of forest health. D.J.K. and S.E. added their knowledge about extensive methodology aspects for using optical, RADAR and LiDAR as well as modelling forest health with remote-sensing techniques. All authors checked and contributed to the final text.

Conflicts of Interest: The authors declare no conflicts of interest.

\section{References}

1. Keenan, R.J.; Reams, G.A.; Achard, F.; de Freitas, J.V.; Grainger, A.; Lindquist, E. Dynamics of global forest area: Results from the FAO Global Forest Resources Assessment 2015. For. Ecol. Manag. 2015, 352, 9-20. [CrossRef]

2. Trumbore, S.; Brando, P.; Hartmann, H. Forest health and global change. Science 2015, 349, 814-818. [CrossRef] [PubMed]

3. Worm, B.; Barbier, E.B.; Beaumont, N.; Duffy, J.E.; Folke, C.; Halpern, B.S.; Jackson, J.B.C.; Lotze, H.K.; Micheli, F.; Palumbi, S.R.; et al. Impacts of biodiversity loss on ocean ecosystem services. Science 2006, 314, 787-790. [CrossRef] [PubMed]

4. Lewis, S.L.; Edwards, D.P.; Galbraith, D. Increasing human dominance of Tropical Forests. Science 2015, 349, 827-832. [CrossRef] [PubMed]

5. Millar, C.I.; Stephenson, N.L. Temperate forest health in an era of emerging megadisturbance. Science 2015, 349, 823-826. [CrossRef] [PubMed]

6. Nemani, R.R.; Keeling, C.D.; Hashimoto, H.; Jolly, W.M.; Piper, S.C.; Tucker, C.J.; Myneni, R.B.; Running, S.W. Climate-driven increases in global terrestrial net primary production from 1982 to 1999. Science 2003, 300, 1560-1563. [CrossRef] [PubMed]

7. Somers, B.; Asner, G.P. Hyperspectral time series analysis of native and invasive species in Hawaiian rainforests. Remote Sens. 2012, 4, 2510-2529. [CrossRef]

8. Gauthier, S.; Bernier, P.; Kuuluvainen, T.; Shvidenko, A.Z.; Schepaschenko, D.G. Boreal forest health and global change. Science 2015, 349, 819-822. [CrossRef] [PubMed]

9. Wingfield, M.J.; Brockerhoff, E.G.; Wingfield, B.D.; Slippers, B. Planted forest health: The need for a global strategy. Science 2015, 349, 832-836. [CrossRef] [PubMed]

10. Mate, A.R.; Deshmukh, R.R. Analysis of effects of air pollution on chlorophyll, water, carotenoid and anthocyanin content of tree leaves using spectral indices. Int. J. Eng. Sci. 2016, 6, 5465-5474.

11. Foley, J.A.; Defries, R.; Asner, G.P.; Barford, C.; Bonan, G.; Carpenter, S.R.; Chapin, F.S.; Coe, M.T.; Daily, G.C.; Gibbs, H.K.; et al. Global consequences of land use. Science 2005, 309, 570-574. [CrossRef] [PubMed]

12. Suorsa, P.; Huhta, E.; Nikula, A.; Nikinmaa, M.; Jäntti, A.; Helle, H.; Hakkarainen, H. Forest management is associated with physiological stress in an old-growth forest passerine. Proc. Biol. Sci. 2003, 270, 963-969. [CrossRef] [PubMed]

13. Woodall, C.W.; Amacher, M.C.; Bechtold, W.A.; Coulston, J.W.; Jovan, S.; Perry, C.H.; Randolph, K.C.; Schulz, B.K.; Smith, G.C.; Tkacz, B.; et al. Status and future of the forest health indicators program of the USA. Environ. Monit. Assess. 2011, 177, 419-436. [CrossRef] [PubMed]

14. Potter, K.M.; Conkling, B.L. Forest Health Monitoring: National Status, Trends, and Analysis 2014; Department of Agriculture Forest Service, Southern Research Station: Asheville, NC, USA, 2015.

15. State of Europe's Forests 2015 Report. Available online: http://foresteurope.org/state-europes-forests-2015report/ (accessed on 15 December 2016).

16. Yang, J.; Dai, G.; Wang, S. China's national monitoring program on ecological functions of forests: An analysis of the protocol and initial results. Forests 2015, 6, 809-826. [CrossRef]

17. Adamowicz, W. Economic indicators of sustainable forest management: Theory versus practice. J. For. Econ. 2003, 9, 27-40. [CrossRef]

18. Kolb, T.E.; Wagner, M.R.; Covington, W.W. Concepts of forest health: utilitarian and ecosystem perspectives. J. For. 1994, 92, 10-15. 
19. McDowell, N.G.; Coops, N.C.; Beck, P.S.A.; Chambers, J.Q.; Gangodagamage, C.; Hicke, J.A.; Huang, C.; Kennedy, R.; Krofcheck, D.J.; Litvak, M.; et al. Global satellite monitoring of climate-induced vegetation disturbances. Trends Plant Sci. 2015, 20, 114-123. [CrossRef] [PubMed]

20. Jetz, W.; Cavender-Bares, J.; Pavlick, R.; Schimel, D.; Davis, F.W.; Asner, G.P.; Guralnick, R.; Kattge, J.; Latimer, A.M.; Moorcroft, P.; et al. Monitoring plant functional diversity from space. Nat. Plants 2016, 2, 1-5.

21. Lausch, A.; Erasmi, S.; King, D.J.; Magdon, P.; Heurich, M. Understanding forest health by remote sensing-Part II-A review of RS approaches and data models. Remote Sens. 2016, in press.

22. Pause, M.; Schweitzer, C.; Rosenthal, M.; Keuck, V.; Bumberger, J.; Dietrich, P.; Heurich, M.; Jung, A.; Lausch, A. In situ/remote sensing integration to assess forest health-A review. Remote Sens. 2016, 8. [CrossRef]

23. Turner, W.; Spector, S.; Gardiner, N.; Fladeland, M.; Sterling, E.; Steininger, M. Remote sensing for biodiversity science and conservation. Trends Ecol. Evol. 2003, 18, 306-314. [CrossRef]

24. Turner, W. Sensing biodiversity. Science 2014, 346, 301-302. [CrossRef] [PubMed]

25. Kuenzer, C.; Ottinger, M.; Wegmann, M.; Guo, H. Earth observation satellite sensors for biodiversity monitoring: Potentials and bottlenecks. Int. J. Remote Sens. 2014, 35, 6599-6647. [CrossRef]

26. White, J.C.; Coops, N.C.; Wulder, M.A.; Vastaranta, M.; Hilker, T.; Tompalski, P. Remote sensing technologies for enhancing forest inventories: A review. Can. J. Remote Sens. 2016, 8992, 1-23. [CrossRef]

27. Asner, G.P.; Knapp, D.E.; Anderson, C.B.; Martin, R.E.; Vaughn, N. Large-scale climatic and geophysical controls on the leaf economics spectrum. Proc. Natl. Acad. Sci. USA 2016, 113, E4043-E4051. [CrossRef] [PubMed]

28. Toth, C.; Jóźków, G. Remote sensing platforms and sensors: A survey. ISPRS J. Photogramm. Remote Sens. 2016, 115, 22-36. [CrossRef]

29. Kuenzer, C.; Bluemel, A.; Gebhardt, S.; Quoc, T.V.; Dech, S. Remote sensing of mangrove ecosystems: A review. Remote Sens. 2011, 3, 878-928. [CrossRef]

30. Banskota, A.; Kayastha, N.; Falkowski, M.J.; Wulder, M.A.; Froese, R.E.; White, J.C. Forest monitoring using Landsat time series data: A review. Can. J. Remote Sens. 2014, 40, 362-384. [CrossRef]

31. Joshi, N.; Mitchard, E.T.A.; Woo, N.; Torres, J.; Moll-rocek, J.; Ehammer, A. Mapping dynamics of deforestation and forest degradation in tropical forests using radar satellite data. Environ. Res. Lett. 2015, 10. [CrossRef]

32. Wulder, M.A.; Masek, J.G.; Cohen, W.B.; Loveland, T.R.; Woodcock, C.E. Opening the archive: How free data has enabled the science and monitoring promise of Landsat. Remote Sens. Environ. 2012, 122, 2-10. [CrossRef]

33. Wulder, M.A.; Coops, N.C. Satellites: Make earth observations open access. Nature 2014, 513, 30-31. [CrossRef] [PubMed]

34. Majasalmi, T.; Rautiainen, M. The potential of Sentinel-2 data for estimating biophysical variables in a boreal forest: A simulation study. Remote Sens. Lett. 2016, 7, 427-436. [CrossRef]

35. Wegmann, M.; Leutner, B.; Dech, S. Remote Sensing and GIS for Ecologists: Using Open Source Software; Pelagic Publishing: Exeter, UK, 2016.

36. Führer, E. Forest functions, ecosystem stability and management. For. Ecol. Manag. 2000, 132, $29-38$. [CrossRef]

37. Hooper, D.U.; Chapin, F.S.; Ewel, J.J.; Hector, A.; Inchausti, P.; Lavorel, S.; Lawton, J.H.; Lodge, D.M.; Loreau, M.; Naeem, S.; et al. Effects of biodiversity on ecosystem functioning: A consensus of current knowledge. Ecol. Monogr. 2005, 75, 3-35. [CrossRef]

38. Emmett Duffy, J. Why biodiversity is important to the functioning of real-world ecosystems. Front. Ecol. Environ. 2009, 7, 437-444. [CrossRef]

39. Bruelheide, H.; Nadrowski, K.; Assmann, T.; Bauhus, J.; Both, S.; Buscot, F.; Chen, X.Y.; Ding, B.; Durka, W.; Erfmeier, A.; et al. Designing forest biodiversity experiments: General considerations illustrated by a new large experiment in subtropical China. Methods Ecol. Evol. 2014, 5, 74-89. [CrossRef]

40. Scherer-Lorenzen, M.; Schulze, E.D.; Don, A.; Schumacher, J.; Weller, E. Exploring the functional significance of forest diversity: A new long-term experiment with temperate tree species (BIOTREE). Perspect. Plant Ecol. Evol. Syst. 2007, 9, 53-70. [CrossRef] 
41. Cardinale, B.J.; Matulich, K.L.; Hooper, D.U.; Byrnes, J.E.; Duffy, E.; Gamfeldt, L.; Balvanera, P.; O'Connor, M.I.; Gonzalez, A. The functional role of producer diversity in ecosystems. Am. J. Bot. 2011, 98, 572-592. [CrossRef] [PubMed]

42. Durieux, L.; Toledo Machado, L.A.; Laurent, H. The impact of deforestation on cloud cover over the Amazon arc of deforestation. Remote Sens. Environ. 2003, 86, 132-140. [CrossRef]

43. Bala, G.; Caldeira, K.; Wickett, M.; Philips, T.J.; Lobell, D.B.; Delire, C.; Mirin, A. Combined climate and Carbon-Cycle effects of large scale deforestation. Proc. Natl. Acad. Sci. USA 2007, 104, 6550-6555. [CrossRef] [PubMed]

44. Quijas, S.; Jackson, L.E.; Maass, M.; Schmid, B.; Raffaelli, D.; Balvanera, P. Plant diversity and generation of ecosystem services at the landscape scale: Expert knowledge assessment. J. Appl. Ecol. 2012, 49, 929-940. [CrossRef]

45. Noss, R.F. Essay indicators for monitoring approach biodiversity: A hierarchical approach. Conserv. Biol. 1990, 4, 355-364. [CrossRef]

46. Lausch, A.; Bannehr, L.; Beckmann, M.; Boehm, C.; Feilhauer, H.; Hacker, J.M.; Heurich, M.; Jung, A.; Klenke, R.; Neumann, C.; et al. Linking earth observation and taxonomic, structural and functional biodiversity: Local to ecosystem perspectives. Indic. Ecol. 2016, 70, 317-339. [CrossRef]

47. Lausch, A.; Blaschke, T.; Haase, D.; Herzog, F.; Syrbe, R.U.; Tischendorf, L.; Walz, U. Understanding and quantifying landscape structure-A review on relevant process characteristics, data models and landscape metrics. Ecol. Model. 2015, 295, 31-41. [CrossRef]

48. Lavorel, S.; Garnier, E. Predicting changes in community composition and ecosystem functioning from plant traits: Revisting the Holy Grail. Funct. Ecol. 2002, 16, 545-556. [CrossRef]

49. Garnier, E.; Laurent, G.; Bellmann, A.; Debain, S.; Berthelier, P.; Ducout, B.; Roumet, C.; Navas, M.L. Consistency of species ranking based on functional leaf traits. New Phytol. 2001, 152, 69-83. [CrossRef]

50. Garnier, E.; Lavorel, S.; Ansquer, P.; Castro, H.; Cruz, P.; Dolezal, J.; Eriksson, O.; Fortunel, C.; Freitas, H.; Golodets, C.; et al. Assessing the effects of land-use change on plant traits, communities and ecosystem functioning in grasslands: A standardized methodology and lessons from an application to 11 European sites. Ann. Bot. 2007, 99, 967-985. [CrossRef] [PubMed]

51. Kleijn, D.; Kohler, F.; Báldi, A.; Batáry, P.; Concepción, E.D.; Clough, Y.; Díaz, M.; Gabriel, D.; Holzschuh, A.; Knop, E.; et al. On the relationship between farmland biodiversity and land-use intensity in Europe. Proc. Biol. Sci. 2009, 276, 903-909. [CrossRef] [PubMed]

52. Feilhauer, H.; Schmidtlein, S. On variable relations between vegetation patterns and canopy reflectance. Ecol. Inform. 2011, 6, 83-92. [CrossRef]

53. Lausch, A.; Heurich, M.; Gordalla, D.; Dobner, H.J.; Gwillym-Margianto, S.; Salbach, C. Forecasting potential bark beetle outbreaks based on spruce forest vitality using hyperspectral remote-sensing techniques at different scales. For. Ecol. Manag. 2013, 308, 76-89. [CrossRef]

54. Lindenmayer, D.B.; Likens, G.E. Effective monitoring of agriculture. J. Environ. Monit. 2011, 13, 1559-1563. [CrossRef] [PubMed]

55. Beck, W.; Müller, J. Impact of heat and drought on tree and stand vitality—Dendroecological methods and first results from level 2-Plots in southern Germany. Schriften aus der Forstlichen Fakultät der Universität Göttingen und der Nordwestdeutschen Forstlichen Versuchsanstalt 2007, 142, 120-127.

56. Boyd, D.S.; Entwistle, J.A.; Flowers, A.G.; Armitage, R.P.; Goldsmith, P.C. Remote sensing the radionuclide contaminated Belarusian landscape: A potential for imaging spectrometry? Int. J. Remote Sens. 2006, 27, 1865-1874. [CrossRef]

57. Møller, A.P.; Mousseau, T.A. Are organisms adapting to ionizing radiation at Chernobyl? Trends Ecol. Evol. 2016, 31, 281-289. [CrossRef] [PubMed]

58. Fetzer, I.; Johst, K.; Schäwe, R.; Banitz, T.; Harms, H.; Chatzinotas, A. The extent of functional redundancy changes as species' roles shift in different environments. Proc. Natl. Acad. Sci. USA 2015, 112, 14888-14893. [CrossRef] [PubMed]

59. Kerr, J.T.; Ostrovsky, M. From space to species: Ecological applications for remote sensing. Trends Ecol. Evol. 2003, 18, 299-305. [CrossRef]

60. Wulder, M.A.; Dymond, C.C.; White, J.C.; Leckie, D.G.; Carroll, A.L. Surveying mountain pine beetle damage of forests: A review of remote sensing opportunities. For. Ecol. Manag. 2006, 221, 27-41. [CrossRef] 
61. Wang, K.; Franklin, S.E.; Guo, X.; Cattet, M. Remote sensing of ecology, biodiversity and conservation: A review from the perspective of remote sensing specialists. Sensors 2010, 10, 9647-9667. [CrossRef] [PubMed]

62. Hansen, M.C.; Potapov, P.V.; Moore, R.; Hancher, M.; Turubanova, S.A.; Tyukavina, A.; Thau, D.; Stehman, S.V.; Goetz, S.J.; Loveland, T.R.; et al. High-resolution global maps of 21st-century forest cover change. Science 2013, 342, 850-853. [CrossRef] [PubMed]

63. Asner, G.P. Organismic remote sensing for tropical forest ecology and conservation. Ann. Missouri Bot. Gard. 2015, 100, 127-140. [CrossRef]

64. Asner, G.P.; Martin, R.E. Airborne spectranomics: Mapping canopy chemical and taxonomic diversity in tropical forests. Front. Ecol. Environ. 2009, 7, 269-276. [CrossRef]

65. Asner, G.P. Biophysical and biochemical sources of variability in canopy reflectance. Analysis 1998, 253, 234-253. [CrossRef]

66. Zarco-Tejada, P.J.; Miller, J.R.; Noland, T.L.; Mohammed, G.H.; Sampson, P.H. Scaling-up and model inversion methods with narrowband optical indices for chlorophyll content estimation in closed forest canopies with hyperspectral data. IEEE Trans. Geosci. Remote Sens. 2001, 39, 1491-1507. [CrossRef]

67. Zarco-Tejada, P.J.; Suarez, L.; Gonzalez-Dugo, V. Spatial resolution effects on chlorophyll fluorescence retrieval in a heterogeneous canopy using hyperspectral imagery and radiative transfer simulation. IEEE Geosci. Remote Sens. Lett. 2013, 10, 937-941. [CrossRef]

68. Ustin, S.L.; Gitelson, A.A.; Jacquemoud, S.; Schaepman, M.; Asner, G.P.; Gamon, J.A.; Zarco-Tejada, P. Retrieval of foliar information about plant pigment systems from high resolution spectroscopy. Remote Sens. Environ. 2009, 113, S67-S77. [CrossRef]

69. Malenovský, Z.; Homolová, L.; Zurita-Milla, R.; Lukeš, P.; Kaplan, V.; Hanuš, J.; Gastellu-Etchegorry, J.P.; Schaepman, M.E. Retrieval of spruce leaf chlorophyll content from airborne image data using continuum removal and radiative transfer. Remote Sens. Environ. 2013, 131, 85-102. [CrossRef]

70. Schlerf, M.; Atzberger, C.; Hill, J.; Buddenbaum, H.; Werner, W.; Schüler, G. Retrieval of chlorophyll and nitrogen in Norway spruce (Picea abies, L. Karst.) using imaging spectroscopy. Int. J. Appl. Earth Obs. Geoinf. 2010, 12, 17-26. [CrossRef]

71. Sampson, P.H.; Zarco-Tejada, P.J.; Mohammed, G.H.; Miller, J.R.; Noland, T.L. Hyperspectral remote sensing of forest condition: Estimating chlorophyll content in tolerant hardwoods. For. Sci. 2003, 49, 381-391.

72. Asner, G.P.; Martin, R.E.; Anderson, C.B.; Knapp, D.E. Quantifying forest canopy traits: Imaging spectroscopy versus field survey. Remote Sens. Environ. 2015, 158, 15-27. [CrossRef]

73. Omari, K.; White, H.P.; Staenz, K.; King, D.J. Retrieval of forest canopy parameters by inversion of the proflair leaf-canopy reflectance model using the LUT approach. IEEE J. Sel. Top. Appl. Earth Obs. Remote Sens. 2013, 6, 715-723. [CrossRef]

74. Schlerf, M.; Atzberger, C. Vegetation structure retrieval in beech and spruce forests using spectrodirectional satellite data. IEEE J. Sel. Top. Appl. Earth Obs. Remote Sens. 2012, 5, 8-17. [CrossRef]

75. Carlson, K.M.; Asner, G.P.; Hughes, R.F.; Ostertag, R.; Martin, R.E. Hyperspectral remote sensing of canopy biodiversity in Hawaiian lowland rainforests. Ecosystems 2007, 10, 536-549. [CrossRef]

76. Asner, G.P.; Martin, R.E. Spectral and chemical analysis of tropical forests: Scaling from leaf to canopy levels. Remote Sens. Environ. 2008, 112, 3958-3970. [CrossRef]

77. Ustin, S.L. Remote sensing of canopy chemistry. Proc. Natl. Acad. Sci. USA 2013, 110, 804-805. [CrossRef] [PubMed]

78. Wang, Z.; Wang, T.; Darvishzadeh, R.; Skidmore, A.K.; Jones, S.; Suarez, L.; Woodgate, W.; Heiden, U.; Heurich, M.; Hearne, J. Vegetation indices for mapping canopy foliar nitrogen in a mixed temperate forest. Remote Sens. 2016, 8. [CrossRef]

79. Lepine, L.C.; Ollinger, S.V.; Ouimette, A.P.; Martin, M.E. Examining spectral reflectance features related to foliar nitrogen in forests: Implications for broad-scale nitrogen mapping. Remote Sens. Environ. 2016, 173, 174-186. [CrossRef]

80. Knyazikhin, Y.; Schull, M.A.; Stenberg, P.; Mõttus, M.; Rautiainen, M.; Yang, Y.; Marshak, A.; Latorre Carmona, P.; Kaufmann, R.K.; Lewis, P.; et al. Hyperspectral remote sensing of foliar nitrogen content. Proc. Natl. Acad. Sci. USA 2013, 110, E185-E192. [CrossRef] [PubMed] 
81. Knox, N.M.; Skidmore, A.K.; Schlerf, M.; de Boer, W.F.; van Wieren, S.E.; van der Waal, C.; Prins, H.H.T.; Slotow, R. Nitrogen prediction in grasses: Effect of bandwidth and plant material state on absorption feature selection. Int. J. Remote Sens. 2010, 31, 691-704. [CrossRef]

82. Asner, G.P.; Anderson, C.B.; Martin, R.E.; Tupayachi, R.; Knapp, D.E.; Sinca, F. Landscape biogeochemistry reflected in shifting distributions of chemical traits in the Amazon forest canopy. Nat. Geosci. 2015, 8, 567-573. [CrossRef]

83. Balzotti, C.S.; Asner, G.P.; Taylor, P.G.; Cleveland, C.C.; Cole, R.; Martin, R.E.; Nasto, M.; Osborne, B.B.; Porder, S.; Townsend, A.R. Environmental controls on canopy foliar $\mathrm{n}$ distributions in a Neotropical lowland forest. Ecol. Appl. 2016, 26, 2449-2462. [CrossRef] [PubMed]

84. Asner, G.P.; Martin, R.E. Spectranomics: Emerging science and conservation opportunities at the interface of biodiversity and remote sensing. Glob. Ecol. Conserv. 2016, 8, 212-219. [CrossRef]

85. Mutanga, O.; Kumar, L. Estimating and mapping grass phosphorus concentration in an African savanna using hyperspectral image data. Int. J. Remote Sens. 2007, 28, 4897-4911. [CrossRef]

86. Porder, S.; Asner, G.P.; Vitousek, P.M. Ground-based and remotely sensed nutrient availability across a tropical landscape. Proc. Natl. Acad. Sci. USA 2005, 102, 10909-10912. [CrossRef] [PubMed]

87. Serrano, L.; Penuelas, J.; Ustin, S.L. Remote sensing of nitrogen and lignin in Mediterranean vegetation from AVIRIS data: Decomposing biochemical from structural signals. Remote Sens. Environ. 2002, 81, 355-364. [CrossRef]

88. Smith, M.L.; Ollinger, S.V.; Martin, M.E.; Aber, J.D.; Hallett, R.A.; Goodale, C.L. Direct estimation of aboveground forest productivity through hyperspectral remote sensing of canopy nitrogen. Ecol. Appl. 2002, 12, 1286-1302. [CrossRef]

89. McManus, K.M.; Asner, G.P.; Martin, R.E.; Dexter, K.G.; Kress, W.J.; Field, C.B. Phylogenetic structure of foliar spectral traits in tropical forest canopies. Remote Sens. 2016, 8. [CrossRef]

90. Thenkabail, P.S.; Lyon, J.G.; Huete, A. Hyperspectral Remote Sensing of Vegetation; CRC Press: Boca Raton, FL, USA, 2016.

91. Klosterman, S.T.; Hufkens, K.; Gray, J.M.; Melaas, E.; Sonnentag, O.; Lavine, I.; Mitchell, L.; Norman, R.; Friedl, M.A.; Richardson, A.D. Evaluating remote sensing of deciduous forest phenology at multiple spatial scales using PhenoCam imagery. Biogeosciences 2014, 11, 4305-4320. [CrossRef]

92. Assal, T.J.; Anderson, P.J.; Sibold, J. Spatial and temporal trends of drought effects in a heterogeneous semi-arid forest ecosystem. For. Ecol. Manag. 2016, 365, 137-151. [CrossRef]

93. Zhu, X.; Wang, T.; Skidmore, A.K.; Darvishzadeh, R.; Niemann, K.O.; Liu, J. Canopy leaf water content estimated using terrestrial LiDAR. Agric. For. Meteorol. 2017, 232, 152-162. [CrossRef]

94. Zarco-Tejada, P.J.; Rueda, C.A.; Ustin, S.L. Water content estimation in vegetation with MODIS reflectance data and model inversion methods. Remote Sens. Environ. 2003, 85, 109-124. [CrossRef]

95. Brosinsky, A.; Lausch, A.; Doktor, D.; Salbach, C.; Merbach, I.; Gwillym-Margianto, S.; Pause, M. Analysis of spectral vegetation signal characteristics as a function of soil moisture conditions using hyperspectral remote sensing. J. Indian Soc. Remote Sens. 2014, 42, 311-324. [CrossRef]

96. Lausch, A.; Salbach, C.; Schmidt, A.; Doktor, D.; Merbach, I.; Pause, M. Deriving phenology of barley with imaging hyperspectral remote sensing. Ecol. Model. 2015, 295, 123-135. [CrossRef]

97. Bergen, K.M.; Goetz, S.J.; Dubayah, R.O.; Henebry, G.M.; Hunsaker, C.T.; Imhoff, M.L.; Nelson, R.F.; Parker, G.G.; Radeloff, V.C. Remote sensing of vegetation 3-D structure for biodiversity and habitat: Review and implications for lidar and radar spaceborne missions. J. Geophys. Res. 2009, 114. [CrossRef]

98. Van Wittenberghe, S.; Verrelst, J.; Rivera, J.P.; Alonso, L.; Moreno, J.; Samson, R. Gaussian processes retrieval of leaf parameters from a multi-species reflectance, absorbance and fluorescence dataset. J. Photochem. Photobiol. B Biol. 2014, 134, 37-48. [CrossRef] [PubMed]

99. Asner, G.P.; Martin, R.E.; Tupayachi, R.; Anderson, C.B.; Sinca, F.; Carranza-Jiménez, L.; Martinez, P. Amazonian functional diversity from forest canopy chemical assembly. Proc. Natl. Acad. Sci. USA 2014, 111, 5604-5609. [CrossRef] [PubMed]

100. Ustin, S.L.; Roberts, D.A.R.A.; Gamon, J.A.; Green, R.O. Using Imaging spectroscopy to study ecosystem processes and properties. Bioscience 2004, 54, 523-534. [CrossRef]

101. Asner, G.P.; Martin, R.E.; Carranza-Jiménez, L.; Sinca, F.; Tupayachi, R.; Anderson, C.B.; Martinez, P. Functional and biological diversity of foliar spectra in tree canopies throughout the Andes to Amazon region. New Phytol. 2014, 204, 127-139. [CrossRef] [PubMed] 
102. Feakins, S.J.; Peters, T.; Wu, M.S.; Shenkin, A.; Salinas, N.; Girardin, C.A.J.; Bentley, L.P.; Blonder, B.; Enquist, B.J.; Martin, R.E.; et al. Production of leaf wax n-alkanes across a tropical forest elevation transect. Org. Geochem. 2016, 100, 89-100. [CrossRef]

103. Feakins, S.J.; Bentley, L.P.; Salinas, N.; Shenkin, A.; Blonder, B.; Goldsmith, G.R.; Ponton, C.; Arvin, L.J.; $\mathrm{Wu}$, M.S.; Peters, T.; et al. Plant leaf wax biomarkers capture gradients in hydrogen isotopes of precipitation from the Andes and Amazon. Geochim. Cosmochim. Acta 2016, 182, 155-172. [CrossRef]

104. Asner, G.P.; Mascaro, J. Mapping tropical forest carbon: Calibrating plot estimates to a simple LiDAR metric. Remote Sens. Environ. 2014, 140, 614-624. [CrossRef]

105. Asner, G.P.; Mascaro, J.; Muller-Landau, H.C.; Vieilledent, G.; Vaudry, R.; Rasamoelina, M.; Hall, J.S.; van Breugel, M. A universal airborne LiDAR approach for tropical forest carbon mapping. Oecologia 2012, 168, 1147-1160. [CrossRef] [PubMed]

106. Asner, G.P.; Mascaro, J.; Anderson, C.; Knapp, D.E.; Martin, R.E.; Kennedy-Bowdoin, T.; van Breugel, M.; Davies, S.; Hall, J.S.; Muller-Landau, H.C.; et al. High-fidelity national carbon mapping for resource management and REDD+. Carbon Balance Manag. 2013, 8. [CrossRef] [PubMed]

107. Marvin, D.C.; Asner, G.P. Spatially explicit analysis of field inventories for national forest carbon monitoring. Carbon Balance Manag. 2016, 11. [CrossRef] [PubMed]

108. Nilsson, M. Estimation of tree heights and stand volume using an airborne lidar system. Remote Sens. Environ. 1996, 56, 1-7. [CrossRef]

109. Suárez, J.C.; Ontiveros, C.; Smith, S.; Snape, S. Use of airborne LiDAR and aerial photography in the estimation of individual tree heights in forestry. Comput. Geosci. 2005, 31, 253-262. [CrossRef]

110. Yao, W.; Krzystek, P.; Heurich, M. Tree species classification and estimation of stem volume and DBH based on single tree extraction by exploiting airborne full-waveform LiDAR data. Remote Sens. Environ. 2012, 123, 368-380. [CrossRef]

111. Dalponte, M.; Bruzzone, L.; Gianelle, D. A system for the estimation of single-tree stem diameter and volume using multireturn LIDAR data. IEEE Trans. Geosci. Remote Sens. 2011, 49, 2479-2490. [CrossRef]

112. Minh, D.H.T.; Le Toan, T.; Rocca, F.; Tebaldini, S.; Villard, L.; Réjou-Méchain, M.; Phillips, O.L.; Feldpausch, T.R.; Dubois-Fernandez, P.; Scipal, K.; et al. SAR tomography for the retrieval of forest biomass and height: Cross-validation at two tropical forest sites in French Guiana. Remote Sens. Environ. 2016, 175, 138-147. [CrossRef]

113. Holmgren, J. Prediction of tree height, basal area and stem volume in forest stands using airborne laser scanning. Scand. J. For. Res. 2004, 19, 543-553. [CrossRef]

114. Lévesque, J.; King, D.J. Airborne digital camera image semivariance for evaluation of forest structural damage at an acid mine site. Remote Sens. Environ. 1999, 68, 112-124. [CrossRef]

115. Levesque, J.; King, D.J. Spatial analysis of radiometeric fractions from high resolution multispectral imagery for modelling individual tree crown and forest canopy structure and health. Remote Sens. Environ. 2003, 84, 589-602. [CrossRef]

116. Kato, A.; Moskal, L.M.; Schiess, P.; Swanson, M.E.; Calhoun, D.; Stuetzle, W. Capturing tree crown formation through implicit surface reconstruction using airborne lidar data. Remote Sens. Environ. 2009, 113, 1148-1162. [CrossRef]

117. Popescu, S.C.; Zhao, K. A voxel-based lidar method for estimating crown base height for deciduous and pine trees. Remote Sens. Environ. 2008, 112, 767-781. [CrossRef]

118. Popescu, S.C.; Wynne, R.H.; Nelson, R.F. Measuring individual tree crown diameter with lidar and assessing its influence on estimating forest volume and biomass. Can. J. Remote Sens. 2003, 29, 564-577. [CrossRef]

119. Pretzsch, H.; Biber, P.; Uhl, E.; Dahlhausen, J.; Rötzer, T.; Caldentey, J.; Koike, T.; van Con, T.; Chavanne, A.; Seifert, T.; et al. Crown size and growing space requirement of common tree species in urban centres, parks, and forests. Urban For. Urban Green. 2015, 14, 466-479. [CrossRef]

120. Falkowski, M.J.; Smith, A.M.S.; Hudak, A.T.; Gessler, P.E.; Vierling, L.A.; Crookston, N.L. Automated estimation of individual conifer tree height and crown diameter via two-dimensional spatial wavelet analysis of lidar data. Can. J. Remote Sens. 2006, 32, 153-161. [CrossRef]

121. Lukeš, P.; Stenberg, P.; Rautiainen, M.; Mõttus, M.; Vanhatalo, K.M. Optical properties of leaves and needles for boreal tree species in Europe. Remote Sens. Lett. 2013, 4, 667-676. [CrossRef] 
122. Roth, K.L.; Casas, A.; Huesca, M.; Ustin, S.L.; Alsina, M.M.; Mathews, S.A.; Whiting, M.L. Leaf spectral clusters as potential optical leaf functional types within California ecosystems. Remote Sens. Environ. 2016, 184, 229-246. [CrossRef]

123. Ball, A.; Sanchez-Azofeifa, A.; Portillo-Quintero, C.; Rivard, B.; Castro-Contreras, S.; Fernandes, G. Patterns of leaf biochemical and structural properties of Cerrado life forms: Implications for remote sensing. PLoS ONE 2015, 10, 1-15. [CrossRef] [PubMed]

124. Goldsmith, G.R.; Bentley, L.P.; Shenkin, A.; Salinas, N.; Blonder, B.; Martin, R.E.; Castro-ccossco, R.; Chambi-porroa, P.; Diaz, S.; Enquist, B.J.; et al. Variation in leaf wettability traits along a tropical montane elevation gradient variation in leaf wettability traits along a tropical montane elevation gradient. New Phytol. 2016. [CrossRef] [PubMed]

125. Ali, A.; Darvishzadeh, R.; Skidmore, A.K.; Duren, I.-V.; Heiden, U.; Heurich, M. Prospect inversion for indirect estimation of leaf dry matter content and specific leaf area. In Proceedings of the 36th International Symposium on Remote Sensing of Environment, Berlin, Germany, 11-15 May 2015; pp. 277-284.

126. Ali, A.M.; Darvishzadeh, R.; Skidmore, A.K.; Duren, I.V.; Heiden, U.; Heurich, M. Estimating leaf functional traits by inversion of PROSPECT: Assessing leaf dry matter content and specific leaf area in mixed mountainous forest. Int. J. Appl. Earth Obs. Geoinf. 2016, 45, 66-76. [CrossRef]

127. De la Riva, E.G.; Olmo, M.; Poorter, H.; Ubera, J.L.; Villar, R. Leaf mass per area (LMA) and its relationship with leaf structure and anatomy in 34 Mediterranean woody species along a water availability gradient. PLoS ONE 2016, 11. [CrossRef] [PubMed]

128. Kokaly, R.F.; Asner, G.P.; Ollinger, S.V.; Martin, M.E.; Wessman, C.A. Characterizing canopy biochemistry from imaging spectroscopy and its application to ecosystem studies. Remote Sens. Environ. 2009, 113, S78-S91. [CrossRef]

129. Wilson, P.J.; Thompson, K.; Hodgson, J.G. Specific leaf area and leaf dry matter content as alternative predictors of plant strategies. New Phytol. 1999, 143, 155-162. [CrossRef]

130. Feilhauer, H.; Doktor, D.; Schmidtlein, S.; Skidmore, A.K. Mapping pollination types with remote sensing. J. Veg. Sci. 2016, 27, 999-1011. [CrossRef]

131. Czerwinski, C.J.; King, D.J.; Mitchell, S.W. Mapping forest growth and decline in a temperate mixed forest using temporal trend analysis of Landsat imagery, 1987-2010. Remote Sens. Environ. 2014, 141, 188-200. [CrossRef]

132. Asner, G.P.; Martin, R.E.; Tupayachi, R.; Emerson, R.; Martinez, P.; Sinca, F.; Powell, G.V.N.; Wright, S.J.; Lugo, A.E. Taxonomy and remote sensing of leaf mass per area (LMA) in humid tropical forests. Ecol. Appl. 2011, 21, 85-98. [CrossRef] [PubMed]

133. Romero-Trigueros, C.; Nortes, P.A.; Alarcón, J.J.; Hunink, J.E.; Parra, M.; Contreras, S.; Droogers, P.; Nicolás, E. Effects of saline reclaimed waters and deficit irrigation on Citrus physiology assessed by UAV remote sensing. Agric. Water Manag. 2016, in press. [CrossRef]

134. Neyret, M.; Bentley, L.P.; Oliveras, I.; Marimon, B.S.; Marimon-Junior, B.H.; Almeida de Oliveira, E.; Barbosa Passos, F.; Castro Ccoscco, R.; dos Santos, J.; Matias Reis, S.; et al. Examining variation in the leaf mass per area of dominant species across two contrasting tropical gradients in light of community assembly. Ecol. Evol. 2016, 6, 5674-5689. [CrossRef] [PubMed]

135. Poorter, H.; Niinemets, U.; Poorter, L.; Wright, I.J.; Villar, R. Causes and consequences of variation in leaf mass per area (LMA): A meta-analysis. New Phytol. 2009, 182, 565-588. [CrossRef] [PubMed]

136. Wang, Z.; Skidmore, A.K.; Darvishzadeh, R.; Heiden, U.; Heurich, M.; Wang, T. Leaf nitrogen content indirectly estimated by leaf traits derived from the PROSPECT model. IEEE J. Sel. Top. Appl. Earth Obs. Remote Sens. 2015, 8, 3172-3182. [CrossRef]

137. Ustin, S.L.; Gamon, J.A. Remote sensing of plant functional types. New Phytol. 2010, 186, 795-816. [CrossRef] [PubMed]

138. Feilhauer, H.; Asner, G.P.; Martin, R.E. Multi-method ensemble selection of spectral bands related to leaf biochemistry. Remote Sens. Environ. 2015, 164, 57-65. [CrossRef]

139. Naidoo, L.; Mathieu, R.; Main, R.; Wessels, K.; Asner, G.P. L-band Synthetic Aperture Radar imagery performs better than optical datasets at retrieving woody fractional cover in deciduous, dry savannahs. Int. J. Appl. Earth Obs. Geoinf. 2016, 52, 54-64. [CrossRef]

140. Main, R.; Mathieu, R.; Kleynhans, W.; Wessels, K.; Naidoo, L.; Asner, G.P. Hyper-temporal C-band SAR for baseline woody structural assessments in deciduous savannas. Remote Sens. 2016, 8, 1-19. [CrossRef] 
141. Tian, F.; Brandt, M.; Liu, Y.Y.; Rasmussen, K.; Fensholt, R. Mapping gains and losses in woody vegetation across global tropical drylands. Glob. Chang. Biol. 2016, 1-13. [CrossRef] [PubMed]

142. Heurich, M.; Thoma, F. Estimation of forestry stand parameters using laser scanning data in temperate, structurally rich natural European beech (Fagus sylvatica) and Norway spruce (Picea abies) forests. Forestry 2008, 81, 645-661. [CrossRef]

143. Næsset, E.; Ørka, H.O.; Solberg, S.; Bollandsås, O.M.; Hansen, E.H.; Mauya, E.; Zahabu, E.; Malimbwi, R.; Chamuya, N.; Olsson, H.; et al. Mapping and estimating forest area and aboveground biomass in miombo woodlands in Tanzania using data from airborne laser scanning, TanDEM-X, RapidEye, and global forest maps: A comparison of estimated precision. Remote Sens. Environ. 2016, 175, 282-300. [CrossRef]

144. Latifi, H.; Fassnacht, F.E.; Müller, J.; Tharani, A.; Dech, S.; Heurich, M. Forest inventories by LiDAR data: A comparison of single tree segmentation and metric-based methods for inventories of a heterogeneous temperate forest. Int. J. Appl. Earth Obs. Geoinf. 2015, 42, 162-174. [CrossRef]

145. Atzberger, C.; Schlerf, M. Object-based stem density estimates in a mid-European forest district based on artificial neural nets: Comparison of Landsat-TM and HyMAP performances. In Proceedings of the 22nd Symposium of the European Association of Remote Sensing Laboratories, Prague, Czech Republic, 4-6 June 2002; pp. 419-427.

146. Bahar, N.H.A.; Ishida, F.Y.; Weerasinghe, L.K.; Guerrieri, R.; O'Sullivan, O.S.; Bloomfield, K.J.; Asner, G.P.; Martin, R.E.; Lloyd, J.; Malhi, Y.; et al. Leaf-level photosynthetic capacity in lowland Amazonian and high-elevation Andean tropical moist forests of Peru. New Phytol. 2016. [CrossRef] [PubMed]

147. Nichol, C.J.; Huemmrich, K.F.; Black, T.A.; Jarvis, P.G.; Walthall, C.L.; Grace, J.; Hall, F.G. Remote sensing of photosynthetic-light-use efficiency of boreal forest. Agric. For. Meteorol. 2000, 101, 131-142. [CrossRef]

148. Drolet, G.G.; Huemmrich, K.F.; Hall, F.G.; Middleton, E.M.; Black, T.A.; Barr, A.G.; Margolis, H.A. A MODIS-derived photochemical reflectance index to detect inter-annual variations in the photosynthetic light-use efficiency of a boreal deciduous forest. Remote Sens. Environ. 2005, 98, 212-224. [CrossRef]

149. Guarini, R.; Nichol, C.; Clement, R.; Loizzo, R.; Grace, J.; Borghetti, M. The utility of MODIS-sPRI for investigating the photosynthetic light-use efficiency in a Mediterranean deciduous forest. Int. J. Remote Sens. 2014, 35, 6157-6172. [CrossRef]

150. Damm, A.; Guanter, L.; Laurent, V.C.E.; Schaepman, M.E.; Schickling, A.; Rascher, U. FLD-based retrieval of sun-induced chlorophyll fluorescence from medium spectral resolution airborne spectroscopy data. Remote Sens. Environ. 2014, 147, 256-266. [CrossRef]

151. Meroni, M.; Rossini, M.; Guanter, L.; Alonso, L.; Rascher, U.; Colombo, R.; Moreno, J. Remote sensing of solar-induced chlorophyll fluorescence: Review of methods and applications. Remote Sens. Environ. 2009, 113, 2037-2051. [CrossRef]

152. Kraft, S.; Del Bello, U.; Bouvet, M.; Drusch, M.; Moreno, J. FLEX: ESA's Earth Explorer 8 candidate mission. Int. Geosci. Remote Sens. Symp. 2012, 7125-7128.

153. Rascher, U.; Alonso, L.; Burkart, A.; Cilia, C.; Cogliati, S.; Colombo, R.; Damm, A.; Drusch, M.; Guanter, L.; Hanus, J.; et al. Sun-induced fluorescence-A new probe of photosynthesis: First maps from the imaging spectrometer HyPlant. Glob. Chang. Biol. 2015, 21, 4673-4684. [CrossRef] [PubMed]

154. Moreno, J.; Alonso, L.; Delegido, J.; Rivera, J.P.; Ruiz-Verdú, A.; Sabater, N.; Tenjo, C.; Verrelst, J.; Vicent, J. Misión Flex (Fluorescence Explorer): Observación de la fluorescencia por teledetección como nueva técnica de estudio del estado de la vegetación terrestre a escala global. Rev. Teledetec. 2014, 41, 111-119. [CrossRef]

155. Damm, A.; Guanter, L.; Paul-Limoges, E.; van der Tol, C.; Hueni, A.; Buchmann, N.; Eugster, W.; Ammann, C.; Schaepman, M.E. Far-red sun-induced chlorophyll fluorescence shows ecosystem-specific relationships to gross primary production: An assessment based on observational and modeling approaches. Remote Sens. Environ. 2015, 166, 91-105. [CrossRef]

156. Rascher, U.; Gioli, B.; Miglietta, F. FLEX_Fluorescence Explorer: A remote sensing approach to quatify spatio-temporal variations of photosynthetic efficiency from space. In Photosynthesis. Energy from the Sun: 14th International Congress on Photosynthesis; Springer Science \& Business Media: Berlin, Germany, 2008; pp. 1387-1390.

157. Chen, B.; Xu, G.; Coops, N.C.; Ciais, P.; Innes, J.L.; Wang, G.; Myneni, R.B.; Wang, T.; Krzyzanowski, J.; $\mathrm{Li}, \mathrm{Q}$; et al. Changes in vegetation photosynthetic activity trends across the Asia-Pacific region over the last three decades. Remote Sens. Environ. 2014, 144, 28-41. [CrossRef] 
158. Balzter, H.; Rowland, C.S.; Saich, P. Forest canopy height and carbon estimation at Monks Wood National Nature Reserve, UK, using dual-wavelength SAR interferometry. Remote Sens. Environ. 2007, 108, 224-239. [CrossRef]

159. Asner, G.P.; Knapp, D.E.; Martin, R.E.; Tupayachi, R.; Anderson, C.B.; Mascaro, J.; Sinca, F.; Chadwick, K.D.; Higgins, M.; Farfan, W.; et al. Targeted carbon conservation at national scales with high-resolution monitoring. Proc. Natl. Acad. Sci. USA 2014, 111, E5016-E5022. [CrossRef] [PubMed]

160. Mascaro, J.; Asner, G.P.; Knapp, D.E.; Kennedy-Bowdoin, T.; Martin, R.E.; Anderson, C.; Higgins, M.; Chadwick, K.D. A tale of two "forests": Random forest machine learning AIDS tropical forest carbon mapping. PLoS ONE 2014, 9. [CrossRef] [PubMed]

161. Asner, G.P.; Clark, J.K.; Mascaro, J.; Galindo García, G.A.; Chadwick, K.D.; Navarrete Encinales, D.A.; Paez-Acosta, G.; Cabrera Montenegro, E.; Kennedy-Bowdoin, T.; Duque, Á.; et al. High-resolution mapping of forest carbon stocks in the Colombian Amazon. Biogeoscience 2012, 9, 2683-2696. [CrossRef]

162. Schimel, D.; Pavlick, R.; Fisher, J.B.; Asner, G.P.; Saatchi, S.; Townsend, P.; Miller, C.; Frankenberg, C.; Hibbard, K.; Cox, P. Observing terrestrial ecosystems and the carbon cycle from space. Glob. Chang. Biol. 2015, 21, 1762-1776. [CrossRef] [PubMed]

163. Patenaude, G.; Hill, R.A.; Milne, R.; Gaveau, D.L.A.; Briggs, B.B.J.; Dawson, T.P. Quantifying forest above ground carbon content using LiDAR remote sensing. Remote Sens. Environ. 2004, 93, 368-380. [CrossRef]

164. Selmants, P.C.; Litton, C.M.; Giardina, C.P.; Asner, G.P. Ecosystem carbon storage does not vary with mean annual temperature in Hawaiian tropical montane wet forests. Glob. Chang. Biol. 2014, 20, 2927-2937. [CrossRef] [PubMed]

165. Chirici, G.; Chiesi, M.; Corona, P.; Salvati, R.; Papale, D.; Fibbi, L.; Sirca, C.; Spano, D.; Duce, P.; Marras, S.; et al. Estimating daily forest carbon fluxes using a combination of ground and remotely sensed data. J. Geophys. Res. Biogeosci. 2015, 121, 266-279. [CrossRef]

166. Thurner, M.; Beer, C.; Carvalhais, N.; Forkel, M.; Santoro, M.; Tum, M.; Schmullius, C. Large-scale variation in boreal and temperate forest carbon turnover rate related to climate. Geophys. Res. Lett. 2016, 43, 4576-4585. [CrossRef]

167. Hopkinson, C.; Chasmer, L.; Barr, A.G.; Kljun, N.; Black, T.A.; McCaughey, J.H. Monitoring boreal forest biomass and carbon storage change by integrating airborne laser scanning, Biometry and eddy covariance data. Remote Sens. Environ. 2016, 181, 82-95. [CrossRef]

168. Gizachew, B.; Duguma, L.A. Forest carbon monitoring and reporting for REDD+: What future for Africa? Environ. Manag. 2016, 58, 922-930. [CrossRef] [PubMed]

169. Turner, D.P.; Guzy, M.; Lefsky, M.A.; Ritts, W.D.; van Tuyl, S.; Law, B.E. Monitoring forest carbon sequestration with remote sensing and carbon cycle modeling. Env. Manag. 2004, 33, 457-466. [CrossRef] [PubMed]

170. Zhang, K.; Kimball, J.S.; Running, S.W. A review of remote sensing based actual evapotranspiration estimation. Wiley Interdiscip. Rev. Water 2016, 3, 834-853. [CrossRef]

171. Anderson, M.C.; Allen, R.G.; Morse, A.; Kustas, W.P. Use of Landsat thermal imagery in monitoring evapotranspiration and managing water resources. Remote Sens. Environ. 2012, 122, 50-65. [CrossRef]

172. Roohi, R.; Webb, J. Thermal and visible remote sensing for estimation of evapotranspiration of rainfed agrosystems and its impact on groundwater in SE Australia. SPIE Commer. Sci. 2016, 9861, 1-12.

173. Mu, Q.; Zhao, M.; Running, S.W.; Kimball, J.S.; McDowell, N.G. Using MODIS weekly evapotranspiration to monitor drought. 2016. [CrossRef]

174. Guerrieri, R.; Lepine, L.; Asbjornsen, H.; Xiao, J.; Ollinger, S.V. Evapotranspiration and water use efficiency in relation to climate and canopy nitrogen in U.S. forests. J. Geophys. Res. Biogeosci. 2016, 121, 2610-2629. [CrossRef]

175. Hirano, T.; Suzuki, K.; Hirata, R. Energy balance and evapotranspiration changes in a larch forest caused by severe disturbance during an early secondary succession. Agric. For. Meteorol. 2017, 232, 457-468. [CrossRef]

176. Cristiano, P.M.; Campanello, P.I.; Bucci, S.J.; Rodriguez, S.A.; Lezcano, O.A.; Scholz, F.G.; Madanes, N.; Di Francescantonio, D.; Carrasco, L.O.; Zhang, Y.J.; et al. Evapotranspiration of subtropical forests and tree plantations: A comparative analysis at different temporal and spatial scales. Agric. For. Meteorol. 2015, 203, 96-106. [CrossRef]

177. Wehr, R.; Munger, J.W.; McManus, J.B.; Nelson, D.D.; Zahniser, M.S.; Davidson, E.A.; Wofsy, S.C.; Saleska, S.R. Seasonality of temperate forest photosynthesis and daytime respiration. Nature 2016, 534, 680-683. [CrossRef] [PubMed] 
178. Migliavacca, M.; Reichstein, M.; Richardson, A.D.; Mahecha, M.D.; Cremonese, E.; Delpierre, N.; Galvagno, M.; Law, B.E.; Wohlfahrt, G.; Andrew Black, T.; et al. Influence of physiological phenology on the seasonal pattern of ecosystem respiration in deciduous forests. Glob. Chang. Biol. 2015, 21, 363-376. [CrossRef] [PubMed]

179. Hilker, T.; Hall, F.G.; Coops, N.C.; Black, A.T.; Jassal, R.; Mathys, A.; Grant, N. Potentials and limitations for estimating daytime ecosystem respiration by combining tower-based remote sensing and carbon flux measurements. Remote Sens. Environ. 2014, 150, 44-52. [CrossRef]

180. Valentini, R.; Matteucci, G.; Dolman, A.J.; Schulze, E.D.; Rebmann, C.; Moors, E.J.; Granier, A.; Gross, P.; Jensen, N.O.; Pilegaard, K.; et al. Respiration as the main determinant of carbon balance in European forests. Nature 2000, 404, 861-865. [CrossRef] [PubMed]

181. Reichstein, M.; Ciais, P.; Papale, D.; Valentini, R.; Running, S.; Viovy, N.; Cramer, W.; Granier, A.; Ogée, J.; Allard, V.; et al. Reduction of ecosystem productivity and respiration during the European summer 2003 climate anomaly: A joint flux tower, remote sensing and modelling analysis. Glob. Chang. Biol. 2007, 13, 634-651. [CrossRef]

182. Janssens, I.A.; Lankreijer, H.; Matteucci, G.; Kowalski, A.S.; Buchmann, N.; Epron, D.; Pilegaard, K.; Kutsch, W.; Longdoz, B.; Grünwald, T.; et al. Productivity overshadows temperature in determining soil and ecosystem respiration across European forests. Glob. Chang. Biol. 2001, 7, 269-278. [CrossRef]

183. Chavana-Bryant, C.; Malhi, Y.; Wu, J.; Asner, G.P.; Anastasiou, A.; Enquist, B.J.; Cosio Caravasi, E.G.; Doughty, C.E.; Saleska, S.R.; Martin, R.E.; et al. Leaf aging of Amazonian canopy trees as revealed by spectral and physiochemical measurements. New Phytol. 2016. [CrossRef] [PubMed]

184. Miller, J.R.; Wu, J.; Boyer, M.G.; Belanger, M.; Hare, E.W. Seasonal patterns in leaf reflectance red-edge characteristics. Int. J. Remote Sens. 1991, 12, 1509-1523. [CrossRef]

185. Wu, J.; Albert, L.P.; Lopes, A.P.; Restrepo-Coupe, N.; Hayek, M.; Wiedemann, K.T.; Guan, K.; Stark, S.C.; Christoffersen, B.; Prohaska, N.; et al. Leaf development and demography explain photosynthetic seasonality in Amazon evergreen forests. Science 2016, 351, 972-976. [CrossRef] [PubMed]

186. Arora, V.K.; Boer, G.J. A parameterization of leaf phenology for the terrestrial ecosystem component of climate models. Glob. Chang. Biol. 2005, 11, 39-59. [CrossRef]

187. Buitenwerf, R.; Rose, L.; Higgins, S.I. Three decades of multi-dimensional change in global leaf phenology. Nat. Clim. Chang. 2015, 5, 364-368. [CrossRef]

188. Panchen, Z.A.; Primack, R.B.; Gallinat, A.S.; Nordt, B.; Stevens, A.D.; Du, Y.; Fahey, R. Substantial variation in leaf senescence times among 1360 temperate woody plant species: Implications for phenology and ecosystem processes. Ann. Bot. 2015, 116, 865-873. [CrossRef] [PubMed]

189. Fridley, J.D. Extended leaf phenology and the autumn niche in deciduous forest invasions. Nature 2012, 485 , 359-362. [CrossRef] [PubMed]

190. Zhang, X.; Friedl, M.A.; Schaaf, C.B.; Strahler, A.H.; Hodges, J.C.F.; Gao, F.; Reed, B.C.; Huete, A. Monitoring vegetation phenology using MODIS. Remote Sens. Environ. 2003, 84, 471-475. [CrossRef]

191. Cleland, E.E.; Chuine, I.; Menzel, A.; Mooney, H.A.; Schwartz, M.D. Shifting plant phenology in response to global change. Trends Ecol. Evol. 2007, 22, 357-365. [CrossRef] [PubMed]

192. Bradley, A.V.; Gerard, F.F.; Barbier, N.; Weedon, G.P.; Anderson, L.O.; Huntingford, C.; Aragão, L.E.O.C.; Zelazowski, P.; Arai, E. Relationships between phenology, radiation and precipitation in the Amazon region. Glob. Chang. Biol. 2011, 17, 2245-2260. [CrossRef]

193. Gunderson, C.A.; Edwards, N.T.; Walker, A.V.; O’Hara, K.H.; Campion, C.M.; Hanson, P.J. Forest phenology and a warmer climate-Growing season extension in relation to climatic provenance. Glob. Chang. Biol. 2012, 18, 2008-2025. [CrossRef]

194. Garonna, I.; de Jong, R.; Schaepman, M.E. Variability and evolution of global land surface phenology over the past three decades (1982-2012). Glob. Chang. Biol. 2016, 22, 1456-1468. [CrossRef] [PubMed]

195. Atkinson, P.M.; Jeganathan, C.; Dash, J.; Atzberger, C. Inter-comparison of four models for smoothing satellite sensor time-series data to estimate vegetation phenology. Remote Sens. Environ. 2012, 123, 400-417. [CrossRef]

196. Broich, M.; Huete, A.; Tulbure, M.G.; Ma, X.; Xin, Q.; Paget, M.; Restrepo-Coupe, N.; Davies, K.; Devadas, R.; Held, A. Land surface phenological response to decadal climate variability across Australia using satellite remote sensing. Biogeosciences 2014, 11, 5181-5198. [CrossRef] 
197. Buermann, W.; Parida, B.; Jung, M.; MacDonald, G.M.; Tucker, C.J.; Reichstein, M. Recent shift in Eurasian boreal forest greening response may be associated with warmer and drier summers. Geophys. Res. Lett. 2014, 41, 1995-2002. [CrossRef]

198. De Jong, R.; Verbesselt, J.; Schaepman, M.E.; de Bruin, S. Trend changes in global greening and browning: Contribution of short-term trends to longer-term change. Glob. Chang. Biol. 2012, 18, 642-655. [CrossRef]

199. Hufkens, K.; Friedl, M.; Sonnentag, O.; Braswell, B.H.; Milliman, T.; Richardson, A.D. Linking near-surface and satellite remote sensing measurements of deciduous broadleaf forest phenology. Remote Sens. Environ. 2012, 117, 307-321. [CrossRef]

200. Chen, J.; Shen, M.; Zhu, X.; Tang, Y. Indicator of flower status derived from in situ hyperspectral measurement in an alpine meadow on the Tibetan Plateau. Ecol. Indic. 2009, 9, 818-823. [CrossRef]

201. Shen, M.; Chen, J.; Zhu, X.; Tang, Y. Yellow flowers can decrease NDVI and EVI values: Evidence from a field experiment in an alpine meadow. Can. J. Remote Sens. 2009, 35, 99-106. [CrossRef]

202. Fang, S.; Tang, W.; Peng, Y.; Gong, Y.; Dai, C.; Chai, R.; Liu, K. Remote estimation of vegetation fraction and flower fraction in oilseed rape with unmanned aerial vehicle data. Remote Sens. 2016, 8. [CrossRef]

203. Abdel-Rahman, E.M.; Makori, D.M.; Landmann, T.; Piiroinen, R.; Gasim, S.; Pellikka, P.; Raina, S.K. The utility of AISA eagle hyperspectral data and random forest classifier for flower mapping. Remote Sens. 2015, 7, 13298-13318. [CrossRef]

204. Landmann, T.; Piiroinen, R.; Makori, D.M.; Abdel-Rahman, E.M.; Makau, S.; Pellikka, P.; Raina, S.K. Application of hyperspectral remote sensing for flower mapping in African savannas. Remote Sens. Environ. 2015, 166, 50-60. [CrossRef]

205. Habel, J.C.; Teucher, M.; Ulrich, W.; Bauer, M.; Rödder, D. Drones for butterfly conservation: Larval habitat assessment with an unmanned aerial vehicle. Landsc. Ecol. 2016, 31, 2385-2395. [CrossRef]

206. Schmidtlein, S.; Feilhauer, H.; Bruelheide, H. Mapping plant strategy types using remote sensing. J. Veg. Sci. 2012, 23, 395-405. [CrossRef]

207. Schmidtlein, S. Imaging spectroscopy as a tool for mapping Ellenberg indicator values. J. Appl. Ecol. 2005, 42, 966-974. [CrossRef]

208. Schmidt, J.; Faßnacht, F.; Lausch, A.; Schmidtlein, S. About the functional signature of landscapes. Ecol. Indic. 2017, 73, 505-512. [CrossRef]

209. Schweiger, A.K.; Schütz, M.; Risch, A.C.; Kneubühler, M.; Haller, R.; Schaepman, M.E. How to predict plant functional types using imaging spectroscopy: Linking vegetation community traits, plant functional types and spectral response. Methods Ecol. Evol. 2016. [CrossRef]

210. Pierce, S.; Brusa, G.; Vagge, I.; Cerabolini, B.E.L. Allocating CSR plant functional types: The use of leaf economics and size traits to classify woody and herbaceous vascular plants. Funct. Ecol. 2013, 27, 1002-1010. [CrossRef]

211. Möckel, T.; Löfgren, O.; Prentice, H.C.; Eklundh, L.; Hall, K. Airborne hyperspectral data predict Ellenberg indicator values for nutrient and moisture availability in dry grazed grasslands within a local agricultural landscape. Ecol. Indic. 2016, 66, 503-516. [CrossRef]

212. Olthof, I.; King, D.J. Development of a forest health index using multispectral airborne digital camera imagery. Can. J. Remote Sens. 2000, 26, 166-176. [CrossRef]

213. Potapov, P.; Yaroshenko, A.; Turubanova, S.; Dubinin, M.; Laestadius, L.; Thies, C.; Aksenov, D.; Egorov, A.; Yesipova, Y.; Glushkov, I.; et al. Mapping the world's intact forest landscapes by remote sensing. Ecol. Soc. 2008, 13, Article 51. [CrossRef]

214. Miles, L.; Newton, A.C.; DeFries, R.S.; Ravilious, C.; May, I.; Blyth, S.; Kapos, V.; Gordon, J.E. A global overview of the conservation status of tropical dry forests. J. Biogeogr. 2006, 33, 491-505. [CrossRef]

215. Stone, C.; Haywood, A. Assessing canopy health of native eucalypt forests. Ecol. Manag. Restor. 2006, 7, 24-30. [CrossRef]

216. Brumelis, G.; Jonsson, B.G.; Kouki, J.; Kuuluvainen, T.; Shorohova, E. Forest naturalness in Northern Europe: Perspectives on processes, structures and species diversity. Silva Fenn. 2011, 45, 807-821. [CrossRef]

217. Kasischke, E.S.; Bourgeauchavez, L.L.; French, N.H.F.; Harrell, P.; Christensen, N.L. Initial observations on using SAR to monitor wildfire scars in boreal forests. Int. J. Remote Sens. 1992, 13, 3495-3501. [CrossRef]

218. Casas, Á.; García, M.; Siegel, R.B.; Koltunov, A.; Ramírez, C.; Ustin, S. Burned forest characterization at single-tree level with airborne laser scanning for assessing wildlife habitat. Remote Sens. Environ. 2016, 175, 231-241. [CrossRef] 
219. Cohen, W.B.; Yang, Z.; Stehman, S.V.; Schroeder, T.A.; Bell, D.M.; Masek, J.G.; Huang, C.; Meigs, G.W. Forest disturbance across the conterminous United States from 1985-2012: The emerging dominance of forest decline. For. Ecol. Manag. 2016, 360, 242-252. [CrossRef]

220. Kane, V.R.; Lutz, J.A.; Roberts, S.L.; Smith, D.F.; McGaughey, R.J.; Povak, N.A.; Brooks, M.L. Landscape-scale effects of fire severity on mixed-conifer and red fir forest structure in Yosemite National Park. For. Ecol. Manag. 2013, 287, 17-31. [CrossRef]

221. Levick, S.R.; Baldeck, C.A.; Asner, G.P. Demographic legacies of fire history in an African savanna. Funct. Ecol. 2015, 29, 131-139. [CrossRef]

222. Smit, I.P.J.; Asner, G.P.; Govender, N.; Vaughn, N.R.; van Wilgen, B.W. An examination of the potential efficacy of high-intensity fires for reversing woody encroachment in savannas. J. Appl. Ecol. 2016, 53, 1623-1633. [CrossRef]

223. King, D.J.; Olthof, I.; Pellikka, P.K.E.; Seed, E.D.; Butson, C. Modelling and mapping damage to forests from an ice storm using remote sensing and environmental data. Nat. Hazards 2005, 35, 321-342. [CrossRef]

224. Polewski, P.; Yao, W.; Heurich, M.; Krzystek, P.; Stilla, U. Detection of fallen trees in ALS point clouds using a Normalized Cut approach trained by simulation. ISPRS J. Photogramm. Remote Sens. 2015, 105, 252-271. [CrossRef]

225. Mücke, W.; Deák, B.; Schroiff, A.; Hollaus, M.; Pfeifer, N. Detection of fallen trees in forested areas using small footprint airborne laser scanning data. Can. J. Remote Sens. 2013, 39, S32-S40. [CrossRef]

226. Achard, F. Determination of deforestation rates of the world's humid tropical forests. Science 2002, 297, 999-1002. [CrossRef] [PubMed]

227. Pisaric, M.F.J.; King, D.J.; Macintosh, A.J.; Bemrose, R. Impact of the 1998 ice storm on the health and growth of sugar maple (Acer saccharum Marsh) dominated forests in Gatineau Park, Quebec. J. Torrey Bot. Soc. 2008, 135, 530-539. [CrossRef]

228. Olthof, I.; King, D.J.; Lautenschlager, R.A. Mapping deciduous forest ice storm damage using Landsat and environmental data. Remote Sens. Environ. 2004, 89, 484-496. [CrossRef]

229. Wu, J.; Wang, T.; Pan, K.; Li, W.; Huang, X. Assessment of forest damage caused by an ice storm using multi-temporal remote-sensing images: A case study from Guangdong Province. Int. J. Remote Sens. 2016, 37, 3125-3142. [CrossRef]

230. Fassnacht, F.E.; Latifi, H.; Ghosh, A.; Joshi, P.K.; Koch, B. Assessing the potential of hyperspectral imagery to map bark beetle-induced tree mortality. Remote Sens. Environ. 2014, 140, 533-548. [CrossRef]

231. Heurich, M.; Ochs, T.; Andresen, T.; Schneider, T. Object-orientated image analysis for the semi-automatic detection of dead trees following a spruce bark beetle (Ips typographus) outbreak. Eur. J. For. Res. 2009, 129, 313-324. [CrossRef]

232. Müller, J.; Brandl, R. Assessing biodiversity by remote sensing in mountainous terrain: The potential of LiDAR to predict forest beetle assemblages. J. Appl. Ecol. 2009, 46, 897-905. [CrossRef]

233. Adamczyk, J.; Osberger, A. Red-edge vegetation indices for detecting and assessing disturbances in Norway spruce dominated mountain forests. Int. J. Appl. Earth Obs. Geoinf. 2015, 37, 90-99. [CrossRef]

234. Ortiz, S.M.; Breidenbach, J.; Kändler, G. Early detection of bark beetle green attack using terraSAR-X and rapideye data. Remote Sens. 2013, 5, 1912-1931. [CrossRef]

235. Meigs, G.W.; Kennedy, R.E.; Cohen, W.B. A Landsat time series approach to characterize bark beetle and defoliator impacts on tree mortality and surface fuels in conifer forests. Remote Sens. Environ. 2011, 115, 3707-3718. [CrossRef]

236. Coops, N.C.; Wulder, M.A. Estimating the reduction in gross primary production due to mountain pine beetle infestation using satellite observations. Int. J. Remote Sens. 2010, 31, 2129-2138. [CrossRef]

237. Coops, N.C.; Waring, R.H.; Wulder, M.A.; White, J.C. Prediction and assessment of bark beetle-induced mortality of lodgepole pine using estimates of stand vigor derived from remotely sensed data. Remote Sens. Environ. 2009, 113, 1058-1066. [CrossRef]

238. Simard, M.; Powell, E.N.; Raffa, K.F.; Turner, M.G. What explains landscape patterns of tree mortality caused by bark beetle outbreaks in Greater Yellowstone? Glob. Ecol. Biogeogr. 2012, 21, 556-567. [CrossRef]

239. Hall, R.J.; Castilla, G.; White, J.C.; Cooke, B.J.; Skakun, R.S. Remote sensing of forest pest damage: A review and lessons learned from a Canadian perspective. Can. Entomol. 2016, 148. [CrossRef]

240. Immitzer, M.; Atzberger, C. Early Detection of Bark Beetle infestation in Norway Spruce (Picea abies, L.) using WorldView-2 Data. Photogramm. Fernerkund. Geoinf. 2014, 2014, 351-367. [CrossRef] 
241. Spasojevic, M.J.; Bahlai, C.A.; Bradley, B.A.; Butterfield, B.J.; Tuanmu, M.N.; Sistla, S.; Wiederholt, R.; Suding, K.N. Scaling up the diversity-resilience relationship with trait databases and remote sensing data: The recovery of productivity after wildfire. Glob. Chang. Biol. 2015, 22, 1421-1432. [CrossRef] [PubMed]

242. Pickell, P.D.; Hermosilla, T.; Frazier, R.J.; Coops, N.C.; Wulder, M.A. Forest recovery trends derived from Landsat time series for North American boreal forests. Int. J. Remote Sens. 2015, 37, 138-149. [CrossRef]

243. Chu, T.; Guo, X.; Takeda, K. Remote sensing approach to detect post-fire vegetation regrowth in Siberian boreal larch forest. Ecol. Indic. 2016, 62, 32-46. [CrossRef]

244. Zhang, K.; Ross, M.; Gann, D. Remote sensing of seasonal changes and disturbances in mangrove forest: A case study from south Florida. Ecosphere 2016, 7, 1-23. [CrossRef]

245. Verbesselt, J.; Umlauf, N.; Hirota, M.; Holmgren, M.; Van Nes, E.H.; Herold, M.; Zeileis, A.; Scheffer, M. Remotely sensed resilience of tropical forests. Nat. Clim. Chang. 2016, 1, 1-5. [CrossRef]

246. Zhao, F.; Meng, R.; Huang, C.; Zhao, M.; Zhao, F.; Gong, P.; Yu, L.; Zhu, Z. Long-term post-disturbance forest recovery in the greater Yellowstone ecosystem analyzed using Landsat time series stack. Remote Sens. 2016, 8. [CrossRef]

247. Bi, J.; Myneni, R.; Lyapustin, A.; Wang, Y.; Park, T.; Chi, C.; Yan, K.; Knyazikhin, Y. Amazon forests' response to droughts: A perspective from the MAIAC product. Remote Sens. 2016, 8. [CrossRef]

248. Bartels, S.F.; Chen, H.Y.H.; Wulder, M.A.; White, J.C. Trends in post-disturbance recovery rates of Canada's forests following wildfire and harvest. For. Ecol. Manag. 2016, 361, 194-207. [CrossRef]

249. Amiri, N.; Yao, W.; Heurich, M.; Krzystek, P.; Skidmore, A.K. Estimation of regeneration coverage in a temperate forest by 3D segmentation using airborne laser scanning data. Int. J. Appl. Earth Obs. Geoinf. 2016, 52, 252-262. [CrossRef]

250. Frolking, S.; Palace, M.W.; Clark, D.B.; Chambers, J.Q.; Shugart, H.H.; Hurtt, G.C. Forest disturbance and recovery: A general review in the context of spaceborne remote sensing of impacts on aboveground biomass and canopy structure. J. Geophys. Res. Biogeosci. 2009, 114. [CrossRef]

251. Neumann, C.; Weiss, G.; Schmidtlein, S.; Itzerott, S.; Lausch, A.; Doktor, D.; Brell, M. Gradient-based assessment of habitat quality for spectral ecosystem monitoring. Remote Sens. 2015, 7, 2871-2898. [CrossRef]

252. Feilhauer, H.; Faude, U.; Schmidtlein, S. Remote sensing of environment combining isomap ordination and imaging spectroscopy to map continuous floristic gradients in a heterogeneous landscape. Remote Sens. Environ. 2011, 115, 2513-2524. [CrossRef]

253. Dahlin, K.M.; Asner, G.P.; Field, C.B. Linking vegetation patterns to environmental gradients and human impacts in a Mediterranean-type island ecosystem. Landsc. Ecol. 2014, 29, 1571-1585. [CrossRef]

254. Harris, A.; Charnock, R.; Lucas, R.M. Hyperspectral remote sensing of peatland floristic gradients. Remote Sens. Environ. 2015, 162, 99-111. [CrossRef]

255. Messinger, M.; Asner, G.P.; Silman, M. Rapid assessments of Amazon forest structure and biomass using small unmanned aerial systems. Remote Sens. 2016, 8. [CrossRef]

256. Higgins, M.A.; Asner, G.P.; Martin, R.E.; Knapp, D.E.; Anderson, C.; Kennedy-Bowdoin, T.; Saenz, R.; Aguilar, A.; Wright, S.J. Linking imaging spectroscopy and LiDAR with floristic composition and forest structure in Panama. Remote Sens. Environ. 2014, 154, 358-367. [CrossRef]

257. Lefsky, M.A.; Cohen, W.B.; Parker, G.G.; Harding, D.J. Lidar remote sensing for ecosystem studies. Bioscience 2002, 52, 19-30. [CrossRef]

258. Rocchini, D.; Balkenhol, N.; Carter, G.A.; Foody, G.M.; Gillespie, T.W.; He, K.S.; Kark, S.; Levin, N.; Lucas, K.; Luoto, M.; et al. Remotely sensed spectral heterogeneity as a proxy of species diversity: Recent advances and open challenges. Ecol. Inform. 2010, 5, 318-329. [CrossRef]

259. Pfeifer, M.; Kor, L.; Nilus, R.; Turner, E.; Cusack, J.; Lysenko, I.; Khoo, M.; Chey, V.K.; Chung, A.C.; Ewers, R.M. Mapping the structure of Borneo's tropical forests across a degradation gradient. Remote Sens. Environ. 2016, 176, 84-97. [CrossRef]

260. Huesca, M.; García, M.; Roth, K.L.; Casas, A.; Ustin, S.L. Canopy structural attributes derived from AVIRIS imaging spectroscopy data in a mixed broadleaf/conifer forest. Remote Sens. Environ. 2016, 182, 208-226. [CrossRef]

261. Cosmopoulos, P.; King, D.J. Temporal analysis of forest structural condition at an acid mine site using multispectral digital camera imagery. Int. J. Remote Sens. 2004, 25, 2259-2275. [CrossRef]

262. Torontow, V.; King, D. Forest complexity modelling and mapping with remote sensing and topographic data: A comparison of three methods. Can. J. Remote Sens. 2011, 37, 387-402. [CrossRef] 
263. Pasher, J.; King, D.J. Development of a forest structure complexity index based on multispectral airborne remote sensing and topographic data. Can. J. For. Res. Can. Rech. For. 2011, 41, 44-58. [CrossRef]

264. Wulder, M.A.; White, J.C.; Nelson, R.F.; Naesset, E.; Ørka, H.O.; Coops, N.C.; Hilker, T.; Bater, C.W.; Gobakken, T. Lidar sampling for large-area forest characterization: A review. Remote Sens. Environ. 2012, 121, 196-209. [CrossRef]

265. Froidevaux, J.S.P.; Zellweger, F.; Bollmann, K.; Jones, G.; Obrist, M.K. From field surveys to LiDAR: Shining a light on how bats respond to forest structure. Remote Sens. Environ. 2016, 175, 242-250. [CrossRef]

266. Townsend, A.R.; Asner, G.P.; Cleveland, C.C. The biogeochemical heterogeneity of tropical forests. Trends Ecol. Evol. 2008, 23, 424-431. [CrossRef] [PubMed]

267. Heilman, G.E., Jr.; Strittholt, J.R.; Slosser, N.C.; Dellasala, D.A. Forest fragmentation of the conterminous United States: Assessing forest intactness through road density and spatial characteristics. Bioscience 2002, 52, 411-422. [CrossRef]

268. Jha, C.S.; Goparaju, L.; Tripathi, A.; Gharai, B.; Raghubanshi, A.S.; Singh, J.S. Forest fragmentation and its impact on species diversity: An analysis using remote sensing and GIS. Biodivers. Conserv. 2005, 14, 1681-1698. [CrossRef]

269. Nagendra, H.; Munroe, D.K.; Southworth, J. From pattern to process: Landscape fragmentation and the analysis of land use/land cover change. Agric. Ecosyst. Environ. 2004, 101, 111-115. [CrossRef]

270. Boentje, J.P.; Blinnikov, M.S. Post-Soviet forest fragmentation and loss in the Green Belt around Moscow, Russia (1991-2001): A remote sensing perspective. Landsc. Urban Plan. 2007, 82, 208-221. [CrossRef]

271. Rogan, J.; Wright, T.M.; Cardille, J.; Pearsall, H.; Ogneva-Himmelberger, Y.; Riemann, R.; Riitters, K.; Partington, K. Forest fragmentation in Massachusetts, USA: A town-level assessment using Morphological spatial pattern analysis and affinity propagation. GIScience Remote Sens. 2016, 53, 506-519. [CrossRef]

272. Pasher, J.; King, D.J. Landscape fragmentation and ice storm damage in eastern ontario forests. Landsc. Ecol. 2006, 21, 477-483. [CrossRef]

273. Kükenbrink, D.; Leiterer, R.; Schneider, F.D.; Schaepman, M.E.; Morsdorf, F. Quantification of hidden canopy volume of airborne laser scanning data using a voxel traversal algorithm. Remote Sens. Environ. 2016, in press.

274. Vauhkonen, J.; Ene, L.; Gupta, S.; Heinzel, J.; Holmgren, J.; Pitkänen, J.; Solberg, S.; Wang, Y.; Weinacker, H.; Hauglin, K.M.; et al. Comparative testing of single-tree detection algorithms under different types of forest. Forestry 2012, 85, 27-40. [CrossRef]

275. Heurich, M. Automatic recognition and measurement of single trees based on data from airborne laser scanning over the richly structured natural forests of the Bavarian Forest National Park. For. Ecol. Manag. 2008, 255, 2416-2433. [CrossRef]

276. Mora, B.; Wulder, M.A.; White, J.C.; Hobart, G. Modeling stand height, volume, and biomass from very high spatial resolution satellite imagery and samples of airborne LIDAR. Remote Sens. 2013, 5, 2308-2326. [CrossRef]

277. Tang, S.J.; Dong, P.L.; Buckles, B.P. Three-dimensional surface reconstruction of tree canopy from lidar point clouds using a region-based level set method. Int. J. Remote Sens. 2013, 34, 1373-1385. [CrossRef]

278. Lahivaara, T.; Seppanen, A.; Kaipio, J.P.; Vauhkonen, J.; Korhonen, L.; Tokola, T.; Maltamo, M. Bayesian approach to tree detection with airborne laser scanning. In Proceedings of the 2012 IEEE International Geoscience and Remote Sensing Symposium (IGARSS), Munich, Germany, 22-27 July 2012; pp. 1641-1644.

279. Reitberger, J.; Schnörr, C.; Heurich, M.; Krzystek, P.; Stilla, U. Towards 3D mapping of forests: A comparative study with first/last pulse and full waveform lidar data. Int. Arch. Photogramm. Remote Sens. Spat. Inf. Sci. 2008, 37, 1397-1403.

280. Reitberger, J.; Krzystek, P.; Stilla, U. Analysis of full waveform LIDAR data for the classification of deciduous and coniferous trees. Int. J. Remote Sens. 2008, 29, 1407-1431. [CrossRef]

281. Heinzel, J.; Koch, B. Investigating multiple data sources for tree species classification in temperate forest and use for single tree delineation. Int. J. Appl. Earth Obs. Geoinf. 2012, 18, 101-110. [CrossRef]

282. Eitel, J.U.H.; Höfle, B.; Vierling, L.A.; Abellán, A.; Asner, G.P.; Deems, J.S.; Glennie, C.L.; Joerg, P.C.; LeWinter, A.L.; Magney, T.S.; et al. Beyond 3-D: The new spectrum of lidar applications for earth and ecological sciences. Remote Sens. Environ. 2016, 186, 372-392. [CrossRef] 
283. Wallerman, J.; Nystrom, K.; Bohlin, J.; Persson, H.J.; Soja, M.J.; Fransson, J.E.S. Estimating forest age and site productivity using time series of 3D remote sensing data. In Proceedings of the 2012 IEEE International Geoscience and Remote Sensing Symposium (IGARSS), Milan, Italy, 26-31 July 2015; pp. 3321-3324.

284. Olthof, I.; King, D.J.; Lautenschlager, R.A. Overstory and understory leaf area index as indicators of forest response to ice storm damage. Ecol. Indic. 2003, 3, 49-64. [CrossRef]

285. Seed, E.D.; King, D.J. Shadow brightness and shadow fraction relations with effective leaf area index: Importance of canopy closure and view angle in mixedwood boreal forest. Can. J. Remote Sens. 2003, 29, 324-335. [CrossRef]

286. Olthof, I.; King, D.J.; Lautenschlager, R.A. Leaf area index change in ice-storm-damaged sugar maple stands1. Forestry 2001, 77, 627-635.

287. Tian, Y.; Dickinson, R.E.; Zhou, L.; Zeng, X.; Dai, Y.; Myneni, R.B.; Knyazikhin, Y.; Zhang, X.; Friedl, M.; $\mathrm{Yu}, \mathrm{H}$; ; et al. Comparison of seasonal and spatial variations of leaf area index and fraction of absorbed photosynthetically active radiation from Moderate Resolution Imaging Spectroradiometer (MODIS) and Common Land Model. J. Geophys. Res. 2004, 109, D01103. [CrossRef]

288. Asner, G.P.; Scurlock, J.M.O.; Hicke, J.A. Global synthesis of leaf area index observations: Implications for ecological and remote sensing studies. Glob. Ecol. Biogeogr. 2003, 12, 191-205. [CrossRef]

289. Zhu, Z.; Bi, J.; Pan, Y.; Ganguly, S.; Anav, A.; Xu, L.; Samanta, A.; Piao, S.; Nemani, R.R.; Myneni, R.B. Global data sets of vegetation Leaf Area Index (LAI)3g and Fraction of Photosynthetically Active Radiation (FPAR)3g derived from Global Inventory Modeling and Mapping Studies (GIMMS) Normalized Difference Vegetation Index (NDVI3g) for the period 1981 to 2011. Remote Sens. 2013, 5, 927-948.

290. Chen, J.M.; Cihlar, J. Retrieving leaf area index of boreal conifer forests using Landsat TM images. Remote Sens. Environ. 1996, 55, 155-162. [CrossRef]

291. Sumnall, M.; Peduzzi, A.; Fox, T.R.; Wynne, R.H.; Thomas, V.A.; Cook, B. Assessing the transferability of statistical predictive models for leaf area index between two airborne discrete return LiDAR sensor designs within multiple intensely managed Loblolly pine forest locations in the south-eastern USA. Remote Sens. Environ. 2016, 176, 308-319. [CrossRef]

292. Disney, M.; Muller, J.P.; Kharbouche, S.; Kaminski, T.; Voßbeck, M.; Lewis, P.; Pinty, B. A new global fAPAR and LAI dataset derived from optimal albedo estimates: Comparison with MODIS products. Remote Sens. 2016, 8. [CrossRef]

293. Zhao, M.; Running, S.W. Drought-Induced Reduction in Global. Science 2010, 329, 940-943. [CrossRef] [PubMed]

294. Running, S.W.; Nemani, R.R.; Heinsch, F.A.; Zhao, M.; Reeves, M.; Hashimoto, H. A continuous satellite-derived measure of global terrestrial primary production. Bioscience 2004, 54, 547-560. [CrossRef]

295. Field, C.B.; Randerson, J.T.; Malmström, C.M. Global net primary production: Combining ecology and remote sensing. Remote Sens. Environ. 1995, 51, 74-88. [CrossRef]

296. Turner, D.P.; Ritts, W.D.; Cohen, W.B.; Gower, S.T.; Running, S.W.; Zhao, M.; Costa, M.H.; Kirschbaum, A.A.; Ham, J.M.; Saleska, S.R.; et al. Evaluation of MODIS NPP and GPP products across multiple biomes. Remote Sens. Environ. 2006, 102, 282-292. [CrossRef]

297. Peregon, A.; Kosykh, N.P.; Mironycheva-Tokareva, N.P.; Ciais, P.; Yamagata, Y. Estimation of biomass and Net Primary Production (NPP) in west Siberian boreal ecosystems: In situ and remote sensing methods. In Novel Methods for Monitoring and Managing Land and Water Resources in Siberia; Mueller, L., Sheudshen, A.K., Eulenstein, F., Eds.; Springer International Publishing: Cham, Switzerland, 2016; pp. 233-252.

298. Liu, L.; Yang, H.; Xu, Y.; Guo, Y.; Ni, J. Forest biomass and net primary productivity in southwestern China: A meta-analysis focusing on environmental driving factors. Forests 2016, 7. [CrossRef]

299. Yan, H.; Zhan, J.; Yang, H.; Zhang, F.; Wang, G.; He, W. Long time-series spatiotemporal variations of NPP and water use efficiency in the lower Heihe River Basin with serious water scarcity. Phys. Chem. Earth Parts $A / B / C$ 2016, 96, 41-49. [CrossRef]

300. Chirici, G.; Chiesi, M.; Corona, P.; Puletti, N.; Mura, M.; Maselli, F. Prediction of forest NPP in Italy by the combination of ground and remote sensing data. Eur. J. For. Res. 2015, 134, 453-467. [CrossRef]

301. Shabanov, N.; Vargas, M.; Miura, T.; Sei, A.; Danial, A. Evaluation of the performance of Suomi NPP VIIRS top of canopy vegetation indices over AERONET sites. Remote Sens. Environ. 2015, 162, 29-44. [CrossRef] 
302. Neumann, M.; Moreno, A.; Thurnher, C.; Mues, V.; Härkönen, S.; Mura, M.; Bouriaud, O.; Lang, M.; Cardellini, G.; Thivolle-Cazat, A.; et al. Creating a regional MODIS satellite-driven net primary production dataset for European forests. Remote Sens. 2016, 8. [CrossRef]

303. Gitelson, A.A.; Peng, Y.; Arkebauer, T.J.; Suyker, A.E. Productivity, absorbed photosynthetically active radiation, and light use efficiency in crops: Implications for remote sensing of crop primary production. J. Plant Physiol. 2015, 177, 100-109. [CrossRef] [PubMed]

304. Tao, X.; Liang, S.; Wang, D. Assessment of five global satellite products of fraction of absorbed photosynthetically active radiation: Intercomparison and direct validation against ground-based data. Remote Sens. Environ. 2015, 163, 270-285. [CrossRef]

305. Senna, M.C.A.; Costa, M.H.; Shimabukuro, Y.E. Fraction of photosynthetically active radiation absorbed by Amazon tropical forest: A comparison of field measurements, modeling, and remote sensing. J. Geophys. Res. 2005, 110. [CrossRef]

306. Gobron, N.; Pinty, B.; Aussedat, O.; Chen, J.M.; Cohen, W.B.; Fensholt, R.; Gond, V.; Huemmrich, K.F.; Lavergne, T.; Mélin, F.; et al. Evaluation of fraction of absorbed photosynthetically active radiation products for different canopy radiation transfer regimes: Methodology and results using Joint Research Center products derived from SeaWiFS against ground-based estimations. J. Geophys. Res. Atmos. 2006, 111. [CrossRef]

307. Myneni, R.B.; Hoffman, S.; Knyazikhin, Y.; Privette, J.L.; Glassy, J.; Tian, Y.; Wang, Y.; Song, X.; Zhang, Y.; Smith, G.R.; et al. Global products of vegetation leaf area and fraction absorbed PAR from year one of MODIS data. Remote Sens. Environ. 2002, 83, 214-231. [CrossRef]

308. Dong, T.; Wu, B.; Meng, J.; Du, X.; Shang, J. Sensitivity analysis of retrieving fraction of absorbed photosynthetically active radiation (FPAR) using remote sensing data. Acta Ecol. Sin. 2016, 36, 1-7. [CrossRef]

309. Tao, X.; Liang, S.; He, T.; Jin, H. Estimation of fraction of absorbed photosynthetically active radiation from multiple satellite data: Model development and validation. Remote Sens. Environ. 2016, 184, 539-557. [CrossRef]

310. Lefsky, M.A.; Harding, D.J.; Keller, M.; Cohen, W.B.; Carabajal, C.C.; Del Bom Espirito-Santo, F.; Hunter, M.O.; de Oliveira, R. Estimates of forest canopy height and aboveground biomass using ICESat. Geophys. Res. Lett. 2005, 32. [CrossRef]

311. Lefsky, M.A.; Cohen, W.B.; Harding, D.J.; Parker, G.G.; Acker, S.A.; Gower, S.T. Lidar remote sensing of above-ground biomass in three biomes. Glob. Ecol. Biogeogr. 2002, 11, 393-399. [CrossRef]

312. Ogaya, R.; Barbeta, A.; Başnou, C.; Peñuelas, J. Satellite data as indicators of tree biomass growth and forest dieback in a Mediterranean holm oak forest. Ann. For. Sci. 2015, 72, 135-144. [CrossRef]

313. Wu, Z.; Dye, D.; Vogel, J.; Middleton, B. Estimating forest and woodland aboveground biomass using active and passive remote sensing. Photogramm. Eng. Remote Sens. 2016, 82, 271-281. [CrossRef]

314. Gómez, C.; White, J.C.; Wulder, M.A. Optical remotely sensed time series data for land cover classification: A review. ISPRS J. Photogramm. Remote Sens. 2016, 116, 55-72. [CrossRef]

315. Lu, D. The potential and challenge of remote sensing-based biomass estimation. Int. J. Remote Sens. 2006, 27, 1297-1328. [CrossRef]

316. Cao, L.; Coops, N.C.; Innes, J.L.; Sheppard, S.R.; Fu, L.; Ruan, H.; She, G. Estimation of forest biomass dynamics in subtropical forests using multi-temporal airborne LiDAR data. Remote Sens. Environ. 2016, 178, 158-171. [CrossRef]

317. Asner, G.P.; Martin, R.E.; Anderson, C.B.; Kryston, K.; Vaughn, N.; Knapp, D.E.; Bentley, L.P.; Shenkin, A.; Salinas, N.; Sinca, F.; et al. Scale dependence of canopy trait distributions along a tropical forest elevation gradient. New Phytol. 2016. [CrossRef] [PubMed]

318. Abelleira Martínez, O.J.; Fremier, A.K.; Günter, S.; Ramos Bendaña, Z.; Vierling, L.; Galbraith, S.M.; Bosque-Pérez, N.A.; Ordoñez, J.C. Scaling up functional traits for ecosystem services with remote sensing: Concepts and methods. Ecol. Evol. 2016, 6, 4359-4371. [CrossRef] [PubMed]

319. Asner, G.P.; Martin, R.E. Canopy phylogenetic, chemical and spectral assembly in a lowland Amazonian forest. New Phytol. 2011, 189, 999-1012. [CrossRef] [PubMed]

320. Leyequien, E.; Verrelst, J.; Slot, M.; Schaepman-Strub, G.; Heitkönig, I.M.A.; Skidmore, A. Capturing the fugitive: Applying remote sensing to terrestrial animal distribution and diversity. Int. J. Appl. Earth Obs. Geoinf. 2007, 9, 1-20. [CrossRef] 
321. Dell, A.I.; Bender, J.A.; Branson, K.; Couzin, I.D.; de Polavieja, G.G.; Noldus, L.P.; Pérez-Escudero, A.; Perona, P.; Straw, A.D.; Wikelski, M.; et al. Automated image-based tracking and its application in ecology. Trends Ecol. Evol. 2014, 29, 417-428. [CrossRef] [PubMed]

322. Ropert-Coudert, Y.; Wilson, R.P. Trends and perspectives in animal-attached remote sensing. Front. Ecol. Environ. 2005, 3, 437-444. [CrossRef]

323. Wikelski, M.; Kays, R.W.; Kasdin, N.J.; Thorup, K.; Smith, J.A.; Swenson, G.W. Going wild: What a global small-animal tracking system could do for experimental biologists. J. Exp. Biol. 2007, 210, 181-186. [CrossRef] [PubMed]

324. Wikelski, M.; Tertitski, G. Living sentinels for climate change effects. Science 2016, 352, 775-776. [CrossRef] [PubMed]

325. Gervasi, V.; Brunberg, S.; Swenson, J.E. An individual-based method to measure animal activity levels: A test on brown bears. Wildl. Soc. Bull. 2006, 34, 1314-1319. [CrossRef]

326. Burton, A.C.; Neilson, E.; Moreira, D.; Ladle, A.; Steenweg, R.; Fisher, J.T.; Bayne, E.; Boutin, S. Wildlife camera trapping: A review and recommendations for linking surveys to ecological processes. J. Appl. Ecol. 2015, 52, 675-685. [CrossRef]

327. Rovero, F.; Zimmermann, F. Camera Trapping for Wildlife Research; Pelagic Publishing: Exeter, UK, 2016.

328. Weingarth, K.; Heibl, C.; Knauer, F.; Zimmermann, F.; Bufka, L.; Heurich, M. First estimation of Eurasian lynx (Lynx lynx) abundance and density using digital cameras and capture-Recapture techniques in a German national park. Anim. Biodivers. Conserv. 2012, 35, 197-207.

329. Rovero, F.; Meek, P.D.; Paul, M. "Which camera trap type and how many do I need?" A review of camera features and study designs for a range of wildlife research applications. Hysterix. Ital. J. Mammal. 2013, 24, 148-156.

330. Grenzdörffer, G.J. UAS-based automatic bird count of a common gull colony. Int. Arch. Photogramm. Remote Sens. 2013, XL-1/W2, 169-174. [CrossRef]

331. Israel, M. A UAV-based roe deer fawm detection system. Int. Arch. Photogramm. Remote Sens. Spat. Inf. Sci. 2012, 38, 1-5.

332. Weingarth, K.; Zimmermann, F.; Knauer, F.; Heurich, M. Evaluation of six digital camera models for the use in capture-recapture sampling of Eurasian Lynx (Lynx lynx ) beim Eurasischen Luchs (Lynx lynx). Waldökologie Landschaftsforschung und Naturschutz 2013, 13, 87-92.

333. Davies, A.B.; Marneweck, D.G.; Druce, D.J.; Asner, G.P. Den site selection, pack composition, and reproductive success in endangered African wild dogs. Behav. Ecol. 2016, 27, 1869-1879. [CrossRef]

334. Davies, A.B.; Tambling, C.J.; Kerley, G.I.H.; Asner, G.P. Limited spatial response to direct predation risk by African herbivores following predator reintroduction. Ecol. Evol. 2016, 6, 5728-5748. [CrossRef] [PubMed]

335. He, K.S.; Bradley, B.A.; Cord, A.F.; Rocchini, D.; Tuanmu, M.N.; Schmidtlein, S.; Turner, W.; Wegmann, M.; Pettorelli, N. Will remote sensing shape the next generation of species distribution models? Remote Sens. Ecol. Conserv. 2015, 1, 4-18. [CrossRef]

336. Pintea, L.; Bauer, M.E.; Bolstad, P.V.; Pusey, A. Matching multiscale remote sensing data to inter-disciplinary conservation needs: The case of chimpanzees in Western Tanzania. In Proceedings of the Pecora 15 Land Satellite Information IV Conference and the ISPRS Commission I Symposium, Denver, CO, USA, 10-15 November 2002.

337. Coops, N.C.; Waring, R.H.; Plowright, A.; Lee, J.; Dilts, T.E. Using remotely-sensed land cover and distribution modeling to estimate tree species migration in the Pacific Northwest Region of North America. Remote Sens. 2016, 8, 65. [CrossRef]

338. Pasher, J.; King, D.; Lindsay, K. Modelling and mapping potential hooded warbler (Wilsonia citrina) habitat using remotely sensed imagery. Remote Sens. Environ. 2007, 107, 471-483. [CrossRef]

339. Barker, R.; King, D.J. Blanding's turtle (Emydoidea blandingii) potential habitat mapping using aerial orthophotographic imagery and object based classification. Remote Sens. 2012, 4, 194-219. [CrossRef]

340. Boelman, N.T.; Holbrook, J.D.; Greaves, H.E.; Krause, J.S.; Chmura, H.E.; Magney, T.S.; Perez, J.H.; Eitel, J.U.H.; Gough, L.; Vierling, K.T.; et al. Airborne laser scanning and spectral remote sensing give a bird's eye perspective on arctic tundra breeding habitat at multiple spatial scales. Remote Sens. Environ. 2016, 184, 337-349. [CrossRef]

341. Richter, R.; Reu, B.; Wirth, C.; Doktor, D. The use of airborne hyperspectral data for tree species classification in a species-rich Central European forest area. Int. J. Appl. Earth Obs. Geoinf. 2016, 52, 464-474. [CrossRef] 
342. Dalponte, M.; Orka, H.O.; Gobakken, T.; Gianelle, D.; Naesset, E. Tree species classification in boreal forests with hyperspectral data. IEEE Trans. Geosci. Remote Sens. 2013, 51, 2632-2645. [CrossRef]

343. Fassnacht, F.E.; Latifi, H.; Steréczak, K.; Modzelewska, A.; Lefsky, M.; Waser, L.T.; Straub, C.; Ghosh, A. Review of studies on tree species classification from remotely sensed data. Remote Sens. Environ. 2016, 186, 64-87. [CrossRef]

344. Immitzer, M.; Atzberger, C.; Koukal, T. Tree species classification with Random forest using very high spatial resolution 8-band worldView-2 satellite data. Remote Sens. 2012, 4, 2661-2693. [CrossRef]

345. Ferreira, M.P.; Zortea, M.; Zanotta, D.C.; Shimabukuro, Y.E.; de Souza Filho, C.R. Mapping tree species in tropical seasonal semi-deciduous forests with hyperspectral and multispectral data. Remote Sens. Environ. 2016, 179, 66-78. [CrossRef]

346. Zhu, X.; Liu, D. Accurate mapping of forest types using dense seasonal Landsat time-series. ISPRS J. Photogramm. Remote Sens. 2014, 96, 1-11. [CrossRef]

347. Lin, C.; Popescu, S.C.; Thomson, G.; Tsogt, K.; Chang, C.I. Classification of tree species in overstorey canopy of subtropical forest using quickbird images. PLoS ONE 2015, 10. [CrossRef] [PubMed]

348. Peerbhay, K.Y.; Mutanga, O.; Ismail, R. Investigating the capability of few strategically placed Worldview-2 multispectral bands to discriminate forest species in KwaZulu-Natal, South Africa. IEEE J. Sel. Top. Appl. Earth Obs. Remote Sens. 2014, 7, 307-316. [CrossRef]

349. Baldeck, C.A.; Asner, G.P.; Martin, R.E.; Anderson, C.B.; Knapp, D.E.; Kellner, J.R.; Wright, S.J. Operational tree species mapping in a diverse tropical forest with airborne imaging spectroscopy. PLoS ONE 2015, 10. [CrossRef] [PubMed]

350. Elatawneh, A.; Rappl, A.; Reshush, N.; Schneider, T.; Knoke, T. Forest tree species identification using phenological stages and RapidEye data: A casestudy in the forest of Freising. In Proceedings of the 5th RESA Workshop, Neustrelitz, Germany, 21 March 2013; pp. 23-28.

351. Hill, R.A.; Wilson, A.K.; George, M.; Hinsley, S.A. Mapping tree species in temperate deciduous woodland using time-series multi-spectral data. Appl. Veg. Sci. 2010, 13, 86-99. [CrossRef]

352. Waser, L.T.; Küchler, M.; Jütte, K.; Stampfer, T. Evaluating the potential of WorldView-2 data to classify tree species and different levels of ash mortality. Remote Sens. 2014, 6, 4515-4545. [CrossRef]

353. Magnard, C.; Morsdorf, F.; Small, D.; Stilla, U.; Schaepman, M.E.; Meier, E. Single tree identification using airborne multibaseline SAR interferometry data. Remote Sens. Environ. 2016, 186, 567-580. [CrossRef]

354. He, K.S.; Rocchini, D.; Neteler, M.; Nagendra, H. Benefits of hyperspectral remote sensing for tracking plant invasions. Divers. Distrib. 2011, 17, 381-392. [CrossRef]

355. Asner, G.P.; Vitousek, P.M. Remote analysis of biological invasion and biogeochemical change. Proc. Natl. Acad. Sci. USA 2005, 102, 4383-4386. [CrossRef] [PubMed]

356. Somers, B.; Asner, G.P. Multi-temporal hyperspectral mixture analysis and feature selection for invasive species mapping in rainforests. Remote Sens. Environ. 2013, 136, 14-27. [CrossRef]

357. Bradley, B.A. Remote detection of invasive plants: A review of spectral, textural and phenological approaches. Biol. Invasions 2014, 16, 1411-1425. [CrossRef]

358. Niphadkar, M.; Nagendra, H. Remote sensing of invasive plants: Incorporating functional traits into the picture. Int. J. Remote Sens. 2016, 37, 3074-3085. [CrossRef]

359. Schneider, L.C.; Fernando, D.N. An untidy cover: Invasion of bracken fern in the shifting cultivation systems of southern Yucatán, Mexico. Biotropica 2010, 42, 41-48. [CrossRef]

360. Blumenthal, D.; Booth, D.T.; Cox, S.E.; Ferrier, C.E. Large-scale aerial images capture details of invasive plant populations. Rangel. Ecol. Manag. 2007, 60, 523-528. [CrossRef]

361. Wolkovich, E.M.; Cleland, E.E. The phenology of plant invasions: A community ecology perspective. Front. Ecol. Environ. 2011, 9, 287-294. [CrossRef]

362. Schimel, D.S.; Asner, G.P.; Moorcroft, P. Observing changing ecological diversity in the Anthropocene. Front. Ecol. Environ. 2013, 11, 129-137. [CrossRef]

363. Jeong, S.J.; Ho, C.H.; Gim, H.J.; Brown, M.E. Phenology shifts at start vs. end of growing season in temperate vegetation over the Northern Hemisphere for the period 1982-2008. Glob. Chang. Biol. 2011, 17, 2385-2399. [CrossRef]

364. Pearson, R.G.; Phillips, S.J.; Loranty, M.M.; Beck, P.S.; Damoulas, T.; Knight, S.J.; Goetz, S.J. Shifts in Arctic vegetation and associated feedbacks under climate change. Nat. Clim. Chang. 2013, 3, 673-677. [CrossRef] 
365. Kelly, A.E.; Goulden, M.L. Rapid shifts in plant distribution with recent climate change. Proc. Natl. Acad. Sci. USA 2008, 105, 11823-11826. [CrossRef] [PubMed]

366. Barrett, F.; McRoberts, R.E.; Tomppo, E.; Cienciala, E.; Waser, L.T. A questionnaire-based review of the operational use of remotely sensed data by national forest inventories. Remote Sens. Environ. 2016, 174, 279-289. [CrossRef]

367. McRoberts, R.E.; Tomppo, E.O. Remote sensing support for national forest inventories. Remote Sens. Environ. 2007, 110, 412-419. [CrossRef]

368. Mäkelä, H.; Pekkarinen, A. Estimation of forest stand volumes by Landsat TM imagery and stand-level field-inventory data. For. Ecol. Manag. 2004, 196, 245-255. [CrossRef]

369. McRoberts, R.; Nelson, M.; Wendt, D. Stratified estimation of forest area using satellite imagery, inventory data, and the k-Nearest Neighbors technique. Remote Sens. Environ. 2002, 82, 457-468. [CrossRef]

370. Wulder, M. Optical remote-sensing techniques for the assessment of forest inventory and biophysical parameters. Prog. Phys. Geogr. 1998, 22, 449-476. [CrossRef]

371. Roberge, C.; Wulff, S.; Reese, H.; Ståhl, G. Improving the precision of sample-based forest damage inventories through two-phase sampling and post-stratification using remotely sensed auxiliary information. Environ. Monit. Assess. 2016, 188, 1-21. [CrossRef] [PubMed]

372. Immitzer, M.; Stepper, C.; Böck, S.; Straub, C.; Atzberger, C. Use of WorldView-2 stereo imagery and National Forest Inventory data for wall-to-wall mapping of growing stock. For. Ecol. Manag. 2016, 359, 232-246. [CrossRef]

373. Bradford, J.B.; Birdsey, R.A.; Joyce, L.A.; Ryan, M.G. Tree age, disturbance history, and carbon stocks and fluxes in subalpine Rocky Mountain forests. Glob. Chang. Biol. 2008, 14, 2882-2897. [CrossRef]

374. Vastaranta, M.; Niemi, M.; Wulder, M.A.; White, J.C.; Nurminen, K.; Litkey, P.; Honkavaara, E.; Holopainen, M.; Hyyppä, J. Forest stand age classification using time series of photogrammetrically derived digital surface models. Scand. J. For. Res. 2016, 31, 194-205. [CrossRef]

375. Iizuka, K.; Tateishi, R. Estimation of $\mathrm{CO}_{2}$ sequestration by the forests in Japan by discriminating precise tree age category using remote sensing techniques. Remote Sens. 2015, 7, 15082-15113. [CrossRef]

376. Pasher, J.; King, D.J. Mapping dead wood distribution in a temperate hardwood forest using high resolution airborne imagery. For. Ecol. Manag. 2009, 258, 1536-1548. [CrossRef]

377. Polewski, P.; Yao, W.; Heurich, M.; Krzystek, P.; Stilla, U. Combining active and semisupervised learning of remote sensing data within a Renyi entropy regularization framework. IEEE J. Sel. Top. Appl. Earth Obs. Remote Sens. 2016, 9, 2910-2922. [CrossRef]

378. Bater, C.W.; Coops, N.C.; Gergel, S.E.; LeMay, V.; Collins, D. Estimation of standing dead tree class distributions in northwest coastal forests using lidar remote sensing. Can. J. For. Res. 2009, 39, 1080-1091. [CrossRef]

379. Olsson, P.O.; Lindström, J.; Eklundh, L. Near real-time monitoring of insect induced defoliation in subalpine birch forests with MODIS derived NDVI. Remote Sens. Environ. 2016, 181, 42-53. [CrossRef]

380. Lottering, R.; Mutanga, O. Optimising the spatial resolution of WorldView-2 pan-sharpened imagery for predicting levels of Gonipterus scutellatus defoliation in KwaZulu-Natal, South Africa. ISPRS J. Photogramm. Remote Sens. 2016, 112, 13-22. [CrossRef]

381. Hall, R.J.; Fernandes, R.A.; Hogg, E.H.; Brandt, J.P.; Butson, C.; Case, B.S.; Leblanc, S.G. Relating aspen defoliation to changes in leaf area derived from field and satellite remote sensing data. Can. J. Remote Sens. 2003, 29, 299-313. [CrossRef]

382. White, J.; Ryan, K.; Key, C.; Running, S. Remote sensing of forest fire severity and vegetation recovery. Int. J. Wildl. Fire 1996, 6, 125-136. [CrossRef]

383. De Beurs, K.M.; Townsend, P.A. Estimating the effect of gypsy moth defoliation using MODIS. Remote Sens. Environ. 2008, 112, 3983-3990. [CrossRef]

384. Eklundh, L.; Johansson, T.; Solberg, S. Mapping insect defoliation in Scots pine with MODIS time-series data. Remote Sens. Environ. 2009, 113, 1566-1573. [CrossRef]

385. Fraser, R.H.; Latifovic, R. Mapping insect-induced tree defoliation and mortality using coarse spatial resolution satellite imagery. Int. J. Remote Sens. 2005, 26, 193-200. [CrossRef]

386. Schwantes, A.M.; Swenson, J.J.; Jackson, R.B. Quantifying drought-induced tree mortality in the open canopy woodlands of central Texas. Remote Sens. Environ. 2016, 181, 54-64. [CrossRef] 
387. Allen, C.D.; Macalady, A.K.; Chenchouni, H.; Bachelet, D.; McDowell, N.; Vennetier, M.; Kitzberger, T.; Rigling, A.; Breshears, D.D.; Hogg, E.T.; et al. A global overview of drought and heat-induced tree mortality reveals emerging climate change risks for forests. For. Ecol. Manag. 2010, 259, 660-684. [CrossRef]

388. Mueller, R.C.; Scudder, C.M.; Porter, M.E.; Talbot Trotter, R.; Gehring, C.A.; Whitham, T.G. Differential tree mortality in response to severe drought: Evidence for long-term vegetation shifts. J. Ecol. 2005, 93, 1085-1093. [CrossRef]

389. Asner, G.P.; Brodrick, P.G.; Anderson, C.B.; Vaughn, N.; Knapp, D.E.; Martin, R.E. Progressive forest canopy water loss during the 2012-2015 California drought. Proc. Natl. Acad. Sci. USA 2015, 113, E249-E255. [CrossRef] [PubMed]

390. Gouveia, C.M.; Trigo, R.M.; Beguería, S.; Vicente-Serrano, S.M. Drought impacts on vegetation activity in the Mediterranean region: An assessment using remote sensing data and multi-scale drought indicators. Glob. Planet. Chang. 2016, in press. [CrossRef]

391. Walsworth, N.A.; King, D.J. Image modelling of forest changes associated with acid mine drainage. Comput. Geosci. 1999, 25, 567-580. [CrossRef]

392. Cohen, W.B.; Yang, Z.; Kennedy, R. Detecting trends in forest disturbance and recovery using yearly Landsat time series: 2. TimeSync-Tools for calibration and validation. Remote Sens. Environ. 2010, 114, 2911-2924. [CrossRef]

393. Fragal, E.H.; Silva, T.S.F.; Novo, E.M.L.D.M. Reconstructing historical forest cover change in the Lower Amazon floodplains using the LandTrendr algorithm. Acta Amaz. 2016, 46, 13-24. [CrossRef]

394. Liang, L.; Hawbaker, T.J.; Zhu, Z.; Li, X.; Gong, P. Forest disturbance interactions and successional pathways in the Southern Rocky Mountains. For. Ecol. Manag. 2016, 375, 35-45. [CrossRef]

395. Shimizu, K.; Ponce-Hernandez, R.; Ahmed, O.S.; Ota, T.; Win, Z.C.; Mizoue, N.; Yoshida, S. Using Landsat time series imagery to detect forest disturbance in selectively logged tropical forests in Myanmar. Can. J. For. Res. 2016. [CrossRef]

396. Fetene, A.; Hilker, T.; Yeshitela, K.; Prasse, R.; Cohen, W.; Yang, Z. Detecting trends in landuse and landcover change of Nech Sar National Park, Ethiopia. Environ. Manag. 2016, 57, 137-147. [CrossRef] [PubMed]

397. Willis, K.S. Remote sensing change detection for ecological monitoring in United States protected areas. Biol. Conserv. 2015, 182, 233-242. [CrossRef]

398. Lawley, V.; Lewis, M.; Clarke, K.; Ostendorf, B. Site-based and remote sensing methods for monitoring indicators of vegetation condition: An Australian review. Ecol. Indic. 2016, 60, 1273-1283. [CrossRef]

399. Holden, C.E.; Woodcock, C.E. An analysis of Landsat 7 and Landsat 8 underflight data and the implications for time series investigations. Remote Sens. Environ. 2015, 185, 16-36. [CrossRef]

400. Roy, D.P.; Wulder, M.A.; Loveland, T.R.; Woodcock, C.E.; Allen, R.G.; Anderson, M.C.; Helder, D.; Irons, J.R.; Johnson, D.M.; Kennedy, R.; et al. Landsat-8: Science and product vision for terrestrial global change research. Remote Sens. Environ. 2014, 145, 154-172. [CrossRef]

401. Joshi, N.; Baumann, M.; Ehammer, A.; Fensholt, R.; Grogan, K.; Hostert, P.; Jepsen, M.R.; Kuemmerle, T.; Meyfroidt, P.; Mitchard, E.T.A.; et al. A review of the application of optical and radar remote sensing data fusion to land use mapping and monitoring. Remote Sens. 2016, 8. [CrossRef]

402. Coppin, P.R.; Bauer, M.E. Digital change detection in forest ecosystems with remote sensing imagery. Remote Sens. Rev. 1996, 13, 207-234. [CrossRef]

403. Woodcock, C.E.; Macomber, S.A.; Pax-Lenney, M.; Cohen, W.B. Monitoring large areas for forest change using Landsat: Generalization across space, time and Landsat sensors. Remote Sens. Environ. 2001, 78, 194-203. [CrossRef]

404. Feng, M.; Sexton, J.O.; Huang, C.; Anand, A.; Channan, S.; Song, X.P.; Song, D.X.; Kim, D.H.; Noojipady, P.; Townshend, J.R. Earth science data records of global forest cover and change: Assessment of accuracy in 1990, 2000, and 2005 epochs. Remote Sens. Environ. 2016, 184, 73-85. [CrossRef]

405. Reiche, J.; Lucas, R.; Mitchell, A.L.; Verbesselt, J.; Hoekman, D.H.; Haarpaintner, J.; Kellndorfer, J.M.; Rosenqvist, A.; Lehmann, E.A.; Woodcock, C.E.; et al. Combining satellite data for better tropical forest monitoring. Nat. Clim. Chang. 2016, 6, 120-122. [CrossRef]

406. Müller, H.; Griffiths, P.; Hostert, P. Long-term deforestation dynamics in the Brazilian Amazon-Uncovering historic frontier development along the Cuiabá-Santarém highway. Int. J. Appl. Earth Obs. Geoinf. 2016, 44, 61-69. [CrossRef] 
407. Riitters, K.; Wickham, J.; Costanza, J.K.; Vogt, P. A global evaluation of forest interior area dynamics using tree cover data from 2000 to 2012. Landsc. Ecol. 2016, 31, 137-148. [CrossRef]

408. Pasquarella, V.J.; Holden, C.E.; Kaufman, L.; Woodcock, C.E. From imagery to ecology: Leveraging time series of all available Landsat observations to map and monitor ecosystem state and dynamics. Remote Sens. Ecol. Conserv. 2016, 2, 1-19. [CrossRef]

409. Cornelissen, J.H.C.; Lavorel, S.; Garnier, E.; Díaz, S.; Buchmann, N.; Gurvich, D.E.; Reich, P.B.; Ter Steege, H.; Morgan, H.D.; Van Der Heijden, M.G.A.; et al. A handbook of protocols for standardised and easy measurement of plant functional traits worldwide. Aust. J. Bot. 2003, 51, 335-380. [CrossRef]

410. Kattge, J.; Díaz, S.; Lavorel, S.; Prentice, I.C.; Leadley, P.; Bönisch, G.; Garnier, E.; Westoby, M.; Reich, P.B.; Wright, I.J.; et al. TRY-A global database of plant traits. Glob. Chang. Biol. 2011, 17, 2905-2935. [CrossRef]

411. Díaz, S.; Kattge, J.; Cornelissen, J.H.C.; Wright, I.J.; Lavorel, S.; Dray, S.; Reu, B.; Kleyer, M.; Wirth, C.; Prentice, I.C.; et al. The global spectrum of plant form and function. Nature 2015, 529, 167-171. [CrossRef] [PubMed]

412. Green, J.L.; Bohannan, B.J.M.; Whitaker, R.J. Microbial biogeography: From taxonomy to traits. Science 2008, 320, 1039-1043. [CrossRef] [PubMed]

413. Violle, C.; Reich, P.B.; Pacala, S.W.; Enquist, B.J.; Kattge, J. The emergence and promise of functional biogeography. Proc. Natl. Acad. Sci. USA 2014, 111, 13690-13696. [CrossRef] [PubMed]

414. Homolová, L.; Malenovský, Z.; Clevers, J.G.P.W.; García-Santos, G.; Schaepman, M.E. Review of optical-based remote sensing for plant trait mapping. Ecol. Complex. 2013, 15, 1-16. [CrossRef]

415. Aasen, H.; Burkart, A.; Bolten, A.; Bareth, G. Generating 3D hyperspectral information with lightweight UAV snapshot cameras for vegetation monitoring: From camera calibration to quality assurance. ISPRS J. Photogramm. Remote Sens. 2015, 108, 245-259. [CrossRef]

416. Guanter, L.; Kaufmann, H.; Segl, K.; Foerster, S.; Rogass, C.; Chabrillat, S.; Kuester, T.; Hollstein, A.; Rossner, G.; Chlebek, C.; et al. The EnMAP spaceborne imaging spectroscopy mission for earth observation. Remote Sens. 2015, 7, 8830-8857. [CrossRef]

417. Lausch, A.; Pause, M.; Doktor, D.; Preidl, S.; Schulz, K. Monitoring and assessing of landscape heterogeneity at different scales. Environ. Monit. Assess. 2013, 185, 9419-9434. [CrossRef] [PubMed]

418. Lausch, A.; Pause, M.; Merbach, I.; Zacharias, S.; Doktor, D.; Volk, M.; Seppelt, R. A new multiscale approach for monitoring vegetation using remote sensing-based indicators in laboratory, field, and landscape. Environ. Monit. Assess. 2013, 185, 1215-1235. [CrossRef] [PubMed]

419. Koukal, T.; Atzberger, C.; Schneider, W. Evaluation of semi-empirical BRDF models inverted against multi-angle data from a digital airborne frame camera for enhancing forest type classification. Remote Sens. Environ. 2014, 151, 27-43. [CrossRef]

420. Koukal, T.; Atzberger, C. Potential of multi-angular data derived from a digital aerial frame camera for forest classification. IEEE J. Sel. Top. Appl. Earth Obs. Remote Sens. 2012, 5, 30-43. [CrossRef]

421. Malenovský, Z.; Bartholomeus, H.M.; Acerbi-Junior, F.W.; Schopfer, J.T.; Painter, T.H.; Epema, G.F.; Bregt, A.K. Scaling dimensions in spectroscopy of soil and vegetation. Int. J. Appl. Earth Obs. Geoinf. 2007, 9, 137-164. [CrossRef]

422. De Vries, F.T.; Manning, P.; Tallowin, J.R.B.; Mortimer, S.R.; Pilgrim, E.S.; Harrison, K.A.; Hobbs, P.J.; Quirk, H.; Shipley, B.; Cornelissen, J.H.C.; et al. Abiotic drivers and plant traits explain landscape-scale patterns in soil microbial communities. Ecol. Lett. 2012, 15, 1230-1239. [CrossRef] [PubMed]

423. Knapp, S.; Kühn, I.; Schweiger, O.; Klotz, S. Challenging urban species diversity: Contrasting phylogenetic patterns across plant functional groups in Germany. Ecol. Lett. 2008, 11, 1054-1064. [CrossRef] [PubMed]

424. Knapp, S.; Kühn, I.; Bakker, J.P.; Kleyer, M.; Klotz, S.; Ozinga, W.A.; Poschlod, P.; Thompson, K.; Thuiller, W.; Römermann, C. How species traits and affinity to urban land use control large-scale species frequency. Divers. Distrib. 2009, 15, 533-546. [CrossRef]

425. Kühn, I.; Nobis, M.P.; Durka, W. Combining spatial and phylogenetic eigenvector filtering in trait analysis. Glob. Ecol. Biogeogr. 2009, 18, 745-758. [CrossRef]

426. Zarco-Tejada, P.J.; González-Dugo, V.; Berni, J.A.J. Fluorescence, temperature and narrow-band indices acquired from a UAV platform for water stress detection using a micro-hyperspectral imager and a thermal camera. Remote Sens. Environ. 2012, 117, 322-337. [CrossRef] 
427. Lausch, A.; Pause, M.; Schmidt, A.; Salbach, C.; Gwillym-Margianto, S.; Merbach, I. Temporal hyperspectral monitoring of chlorophyll, LAI, and water content of barley during a growing season. Can. J. Remote Sens. 2013, 39, 191-207. [CrossRef]

428. Bellvert, J.; Zarco-Tejada, P.J.; Marsal, J.; Girona, J.; González-Dugo, V.; Fereres, E. Vineyard irrigation scheduling based on airborne thermal imagery and water potential thresholds. Aust. J. Grape Wine Res. 2016, 22, 307-315. [CrossRef]

429. Buitrago, M.F.; Groen, T.A.; Hecker, C.A.; Skidmore, A.K. Changes in thermal infrared spectra of plants caused by temperature and water stress. ISPRS J. Photogramm. Remote Sens. 2016, 111, 22-31. [CrossRef]

430. Yang, Y.; Guan, H.; Batelaan, O.; McVicar, T.R.; Long, D.; Piao, S.; Liang, W.; Liu, B.; Jin, Z.; Simmons, C.T. Contrasting responses of water use efficiency to drought across global terrestrial ecosystems. Sci. Rep. 2016, 6. [CrossRef] [PubMed]

431. Zarco-Tejada, P.J.; González-Dugo, M.V.; Fereres, E. Seasonal stability of chlorophyll fluorescence quantified from airborne hyperspectral imagery as an indicator of net photosynthesis in the context of precision agriculture. Remote Sens. Environ. 2016, 179, 89-103. [CrossRef]

432. Haboudane, D.; Miller, J.R.; Tremblay, N.; Zarco-Tejada, P.J.; Dextraze, L. Integrated narrow-band vegetation indices for prediction of crop chlorophyll content for application to precision agriculture. Remote Sens. Environ. 2002, 81, 416-426. [CrossRef]

433. Rocchini, D.; Boyd, D.S.; Feret, J.B.; He, K.S.; Lausch, A.; Nagendra, H.; Wegmann, M.; Pettorelli, N. Satellite remote sensing to monitor species diversity: Potential and pitfalls. Remote Sens. Ecol. Conserv. 2015, 2, 25-36. [CrossRef]

434. Muro, J.; Van Doninck, J.; Tuomisto, H.; Higgins, M.A.; Moulatlet, G.M.; Ruokolainen, K. Floristic composition and across-track reflectance gradient in Landsat images over Amazonian forests. ISPRS J. Photogramm. Remote Sens. 2016, 119, 361-372. [CrossRef]

435. Baldeck, C.A.; Tupayachi, R.; Sinca, F.; Jaramillo, N.; Asner, G.P. Environmental drivers of tree community turnover in western Amazonian forests. Ecography 2016, 39, 1089-1099. [CrossRef]

436. Vaglio Laurin, G.; Puletti, N.; Hawthorne, W.; Liesenberg, V.; Corona, P.; Papale, D.; Chen, Q.; Valentini, R. Discrimination of tropical forest types, dominant species, and mapping of functional guilds by hyperspectral and simulated multispectral Sentinel-2 data. Remote Sens. Environ. 2016, 176, 163-176. [CrossRef]

437. Berner, L.T.; Law, B.E. Plant traits, productivity, biomass and soil properties from forest sites in the Pacific Northwest, 1999-2014. Sci. Data 2016, 3. [CrossRef] [PubMed]

438. Goldstein, M.I.; Lacher, T.E.; Woodbridge, B.; Bechard, M.J.; Canavelli, S.B.; Zaccagnini, M.E.; Cobb, G.P.; Scollon, E.J.; Tribolet, R.; Hooper, M.J. Monocrotophos-induced mass mortality of Swainson's hawks in Argentina, 1995-96. Ecotoxicology 1999, 8, 201-214. [CrossRef]

439. Suorsa, P.; Helle, H.; Koivunen, V.; Huhta, E.; Nikula, A.; Hakkarainen, H. Effects of forest patch size on physiological stress and immunocompetence in an area-sensitive passerine, the Eurasian treecreeper (Certhia familiaris): An experiment. Proc. R. Soc. 2004, 271, 435-440. [CrossRef] [PubMed]

440. Martínez-Mota, R.; Valdespino, C.; Sánchez-Ramos, M.A.; Serio-Silva, J.C. Effects of forest fragmentation on the physiological stress response of black howler monkeys. Anim. Conserv. 2007, 10, 374-379. [CrossRef]

441. Sipari, S.; Haapakoski, M.; Klemme, I.; Palme, R.; Sundell, J.; Ylönen, H. Changing winter conditions in the boreal forest: The effects of fluctuating temperature and predation risk on activity and physiological stress level in bank voles. Behav. Ecol. Sociobiol. 2016, 70, 1571-1579. [CrossRef]

442. Adrados, C.; Verheyden-Tixier, H.; Cargnelutti, B.; Pepin, D.; Janeau, G. GPS approach to study fine-scale site use by wild red deer during active and inactive behaviours. Wildl. Soc. Bull. 2003, 31, 544-552.

443. Löttker, P.; Rummel, A.; Traube, M.; Stache, A.; Šustr, P.; Müller, J.; Heurich, M. New possibilities of observing animal behaviour from a distance using activity sensors in GPS-collars: An attempt to calibrate remotely collected activity data with direct behavioural observations in red deer Cervus elaphus. Wildl. Biol. 2009, 15, 425-434. [CrossRef]

444. Witt, M.J.; Åkesson, S.; Broderick, A.C.; Coyne, M.S.; Ellick, J.; Formia, A.; Hays, G.C.; Luschi, P.; Stroud, S.; Godley, B.J. Assessing accuracy and utility of satellite-tracking data using Argos-linked Fastloc-GPS. Anim. Behav. 2010, 80, 571-581. [CrossRef]

445. Witt, M.J.; Åkesson, S.; Broderick, A.C.; Coyne, M.S.; Ellick, J.; Formia, A.; Hays, G.C.; Luschi, P.; Stroud, S.; Godley, B.J. Assessing accuracy and utility of satellite-tracking data using Argos-linked Fastloc-GPS. Anim. Behav. 2010, 80, 571-581. [CrossRef] 
446. Weingarth, K.; Zeppenfeld, T.; Heibl, C.; Heurich, M.; Bufka, L.; Daniszová, K.; Müller, J. Hide and seek: Extended camera-trap session lengths and autumn provide best parameters for estimating lynx densities in mountainous areas. Biodivers. Conserv. 2015, 24, 2935-2952. [CrossRef]

447. Naugle, D.; Jenks, J.; Krenohan, B. Use of thermal infrared sensing to estimate density of white-tailed deer. Wildl. Soc. Bull. 1996, 24, 37-43.

448. Chrétien, L.P.; Théau, J.; Ménard, P. Wildlife multispecies remote sensing using visible and thermal infrared imagery acquired from an unmanned aerial vehicle (UAV). ISPRS Int. Arch. Photogramm. Remote Sens. Spat. Inf. Sci. 2015, XL-1/W4, 241-248. [CrossRef]

449. Curtis, P.D.; Boldgiv, B.; Mattison, P.M.; Boulanger, J.R. Estimating deer abundance in suburban areas with infrared-triggered cameras. Hum. Wildl. Interact. 2009, 3, 116-128.

450. Saatchi, S.; Buermann, W.; ter Steege, H.; Mori, S.; Smith, T.B. Modeling distribution of Amazonian tree species and diversity using remote sensing measurements. Remote Sens. Environ. 2008, 112, 2000-2017. [CrossRef]

451. Cord, A.F.; Meentemeyer, R.K.; Leitáo, P.J.; Václavǐk, T. Modelling species distributions with remote sensing data: Bridging disciplinary perspectives. J. Biogeogr. 2013, 40, 2226-2227. [CrossRef]

452. Mulder, V.L.; de Bruin, S.; Schaepman, M.E.; Mayr, T.R. The use of remote sensing in soil and terrain mapping-A review. Geoderma 2011, 162, 1-19. [CrossRef]

453. Mulder, V.L.; de Bruin, S.; Weyermann, J.; Kokaly, R.F.; Schaepman, M.E. Characterizing regional soil mineral composition using spectroscopy and geostatistics. Remote Sens. Environ. 2013, 139, 415-429. [CrossRef]

454. Wulf, H.; Schaepman, M.E.; Jörg, P.C. Remote Sesing of Soils; University of Zurich: Zurich, Switzerland, 2014; pp. 1-71.

455. Rosenqvist, Å.; Milne, A.; Lucas, R.; Imhoff, M.; Dobson, C. A review of remote sensing technology in support of the Kyoto Protocol. Environ. Sci. Policy 2003, 6, 441-455. [CrossRef]

456. Lessells, C.M.; Both, C.; Bouwhuis, S.; Visser, M.E. Climate change and population declines in a long distance migratory bird. Nature 2006, 441, 81-83.

457. Elith, J.; Leathwick, J. Species distribution models: Ecological explanation and prediction across space and time. Annu. Rev. Ecol. Evol. Syst. 2009, 40, 677-697. [CrossRef]

458. Pettorelli, N. The Normalized Difference Vegetation Index; Oxford University Press: Oxford, UK, 2014.

459. Carreiras, J.M.B.; Jones, J.; Lucas, R.M.; Gabriel, C. Land use and land cover change dynamics across the Brazilian Amazon: Insights from extensive time-series analysis of remote sensing data. PLoS ONE 2014, 9. [CrossRef] [PubMed]

460. Estel, S.; Kuemmerle, T.; Levers, C.; Baumann, M.; Hostert, P. Mapping cropland-use intensity across Europe using MODIS NDVI time series. Environ. Res. Lett. 2016, 11, 24015. [CrossRef]

461. Deblauwe, V.; Droissart, V.; Bose, R.; Sonké, B.; Blach-Overgaard, A.; Svenning, J.C.; Wieringa, J.J.; Ramesh, B.R.; Stévart, T.; Couvreur, T.L.P. Remotely sensed temperature and precipitation data improve species distribution modelling in the tropics. Glob. Ecol. Biogeogr. 2016, 25, 443-454. [CrossRef]

462. Franklin, J.; Serra-Diaz, J.M.; Syphard, A.D.; Regan, H.M. Global change and terrestrial plant community dynamics. Proc. Natl. Acad. Sci. USA 2016, 113, 3725-3734. [CrossRef] [PubMed]

463. Boiffin, J.; Badeau, V.; Bréda, N. Species distribution models may misdirect assisted migration: Insights from the introduction of Douglas-fir to Europe. Ecol. Appl. 2016. [CrossRef]

464. Kuemmerle, T.; Perzanowski, K.; Chaskovskyy, O.; Ostapowicz, K.; Halada, L.; Bashta, A.T.; Kruhlov, I.; Hostert, P.; Waller, D.M.; Radeloff, V.C. European bison habitat in the Carpathian Mountains. Biol. Conserv. 2010, 143, 908-916. [CrossRef]

465. Heurich, M.; Hilger, A.; Küchenhoff, H.; Andrén, H.; Bufka, L.; Krofel, M.; Mattisson, J.; Odden, J.; Persson, J.; Rauset, G.R.; et al. Activity patterns of Eurasian lynx are modulated by light regime and individual traits over a wide latitudinal range. PLOS ONE 2014, 9. [CrossRef] [PubMed]

466. Goodall, J. Securing a future for chimpanzees. Nature 2010, 466, 180-181. [CrossRef] [PubMed]

467. Wulder, M.A.; White, J.C.; Bentz, B.; Alvarez, M.F.; Coops, N.C. Estimating the probability of mountain pine beetle red-attack damage. Remote Sens. Environ. 2006, 101, 150-166. [CrossRef]

468. Fassnacht, F.E.; Latifi, H.; Koch, B. An angular vegetation index for imaging spectroscopy data-Preliminary results on forest damage detection in the Bavarian National Park, Germany. Int. J. Appl. Earth Obs. Geoinf. 2012, 19, 308-321. [CrossRef] 
469. Ghosh, A.; Fassnacht, F.E.; Joshi, P.K.; Koch, B. A framework for mapping tree species combining hyperspectral and LiDAR data: Role of selected classifiers and sensor across three spatial scales. Int. J. Appl. Earth Obs. Geoinf. 2014, 26, 49-63. [CrossRef]

470. Lishawa, S.C.; Treering, D.J.; Vail, L.M.; McKenna, O.; Grimm, E.C.; Tuchman, N.C. Reconstructing plant invasions using historical aerial imagery and pollen core analysis: Typha in the Laurentian Great Lakes. Divers. Distrib. 2013, 19, 14-28. [CrossRef]

471. Wittmann, F.; Anhuf, D.; Funk, W.J. Tree species distribution and community structure of central Amazonian várzea forests by remote-sensing techniques. J. Trop. Ecol. 2002, 18, 805-820. [CrossRef]

472. Ioki, K.; Tsuyuki, S.; Hirata, Y.; Phua, M.H.; Wong, W.V.C.; Ling, Z.Y.; Johari, S.A.; Korom, A.; James, D.; Saito, H.; et al. Evaluation of the similarity in tree community composition in a tropical rainforest using airborne LiDAR data. Remote Sens. Environ. 2016, 173, 304-313. [CrossRef]

473. Grime, J.P.; Thompson, K.; Hunt, R.; Hodgson, J.G.; Cornelissen, J.H.C.; Rorison, I.H.; Hendry, G.A.F.; Ashenden, T.W.; Askew, A.P.; Band, S.R.; et al. Integrated screening validates primary axes of specialisation in plants. Oikos 1997, 79, 259-281. [CrossRef]

474. Lavorel, S.; McIntyre, S.; Landsberg, J.; Forbes, T.D.A. Plant functional classifications: From general groups to specific groups based on response to disturbance. Trends Ecol. Evol. 1997, 12, 474-478. [CrossRef]

475. Tilman, D.; Knops, J.; Wedin, D.; Reich, P.; Ritchie, M.; Siemann, E. The Influence of functional diversity and composition on ecosystem processes. Science 1997, 277, 1300-1302. [CrossRef]

476. Grime, J.P. Vegetation classification by reference to strategies. Nature 1974, 250, 26-31. [CrossRef]

477. Hodgson, J.G.; Wilson, P.J.; Hunt, R.; Grime, J.P.; Thompson, K. Allocating C-S-R plant functional types: A soft approach to a hard problem. Oikos 1999, 85, 282-294. [CrossRef]

478. Loveland, T.R.; Reed, B.C.; Brown, J.F.; Ohlen, D.O.; Zhu, Z.; Yang, L.; Merchant, J.W. Development of a global land cover characteristics database and IGBP DISCover from $1 \mathrm{~km}$ AVHRR data. Int. J. Remote Sens. 2000, 21, 1303-1330. [CrossRef]

479. Landsat Detection of Trends in Disturbance and Recovery-LandTrend. Available online: http://www.fsl. orst.edu/larse (accessed on 15 December 2016).

480. Kennedy, R.E.; Yang, Z.; Cohen, W.B. Detecting trends in forest disturbance and recovery using yearly Landsat time series: 1. LandTrendr-Temporal segmentation algorithms. Remote Sens. Environ. 2010, 114, 2897-2910. [CrossRef]

481. Goward, S.N.; Dye, D.G. Evaluating North American net primary productivity with satellite observations. Adv. Sp. Res. 1987, 7, 165-174. [CrossRef]

482. Bustamante, M.M.C.; Roitman, I.; Aide, T.M.; Alencar, A.; Anderson, L.O.; Aragão, L.; Asner, G.P.; Barlow, J.; Berenguer, E.; Chambers, J.; et al. Toward an integrated monitoring framework to assess the effects of tropical forest degradation and recovery on carbon stocks and biodiversity. Glob. Chang. Biol. 2016, 22, 92-109. [CrossRef] [PubMed]

483. Ollinger, S.V. Sources of variability in canopy reflectance and the convergent properties of plants. New Phytol. 2011, 189, 375-394. [CrossRef] [PubMed]

484. Goetz, S.J.; Baccini, A.; Laporte, N.T.; Johns, T.; Walker, W.; Kellndorfer, J.; Houghton, R.A.; Sun, M. Mapping and monitoring carbon stocks with satellite observations: A comparison of methods. Carbon Balance Manag. 2009, 4. [CrossRef] [PubMed]

485. Aguiar, A.P.D.; Ometto, J.P.; Nobre, C.; Lapola, D.M.; Almeida, C.; Vieira, I.C.; Soares, J.V.; Alvala, R.; Saatchi, S.; Valeriano, D.; et al. Modeling the spatial and temporal heterogeneity of deforestation-driven carbon emissions: The INPE-EM framework applied to the Brazilian Amazon. Glob. Chang. Biol. 2012, 18, 3346-3366. [CrossRef]

486. Molina, P.X.; Asner, G.P.; Abadía, M.F.; Manrique, J.C.O.; Diez, L.A.S.; Valencia, R. Spatially-explicit testing of a general aboveground carbon density estimation model in a western Amazonian forest using airborne LiDAR. Remote Sens. 2016, 8. [CrossRef]

487. Atkin, O.K.; Bloomfield, K.J.; Reich, P.B.; Tjoelker, M.G.; Asner, G.P.; Bonal, D.; Bönisch, G.; Bradford, M.G.; Cernusak, L.A.; Cosio, E.G.; et al. Global variability in leaf respiration in relation to climate, plant functional types and leaf traits. New Phytol. 2015, 206, 614-636. [CrossRef] [PubMed]

488. Avitabile, V.; Herold, M.; Heuvelink, G.B.M.; Lewis, S.L.; Phillips, O.L.; Asner, G.P.; Armston, J.; Ashton, P.S.; Banin, L.; Bayol, N.; et al. An integrated pan-tropical biomass map using multiple reference datasets. Glob. Chang. Biol. 2016, 22, 1406-1420. [CrossRef] [PubMed] 
489. Asner, G.P. Organismic remote sensing for tropical forest ecology and conservation. Ann. Missouri Bot. Gard. 2015, 100, 127-140. [CrossRef]

490. Asner, G.P.; Martin, R.E.; Suhaili, A. bin sources of canopy chemical and spectral diversity in lowland bornean forest. Ecosystems 2012, 15, 504-517. [CrossRef]

491. Behera, S.K.; Misra, M.K.; Chhabra, A.; Palria, S.; Dadhwal, V.K.; Haripriya, G.S.; Lu, D.; Chen, Q.; Wang, G.; Liu, L.; et al. A survey of remote sensing-based aboveground biomass estimation methods in forest ecosystems. Biomass Bioenergy 2006, 22, 31-38.

492. Xu, C.; Morgenroth, J.; Manley, B. Integrating data from discrete return airborne LiDAR and optical sensors to enhance the accuracy of forest description: A review. Curr. For. Rep. 2015, 1, 206-219. [CrossRef]

493. Xu, C.; Hantson, S.; Holmgren, M.; van Nes, E.H.; Staal, A.; Scheffer, M. Remotely sensed canopy height reveals three pantropical ecosystem states. Ecology 2016, 97, 2518-2521. [CrossRef] [PubMed]

494. Vaughn, N.R.; Asner, G.P.; Giardina, C.P. Long-term fragmentation effects on the distribution and dynamics of canopy gaps in a tropical montane forest. Ecosphere 2015, 6. [CrossRef]

495. Dolman, A.J.; Gerbig, C.; Noilhan, J.; Sarrat, C.; Miglieta, F. Detecting regional variability in sources and sinks of carbon dioxide: A synthesis. Biogeoscience 2009, 6, 2331-2355. [CrossRef]

496. Rossini, M.; Nedbal, L.; Guanter, L.; Ač, A.; Alonso, L.; Burkart, A.; Cogliati, S.; Colombo, R.; Damm, A.; Drusch, M.; et al. Red and far red Sun-induced chlorophyll fluorescence as a measure of plant photosynthesis. Geophys. Res. Lett. 2015, 42, 1632-1639. [CrossRef]

497. Fiorani, F.; Schurr, U. Future scenarios for plant phenotyping. Annu. Rev. Plant Biol. 2013, 64, $267-291$. [CrossRef] [PubMed]

498. Lawton, J.H.; Naeem, S.; Woodfin, R.M.; Brown, V.K.; Gange, A.; Godfray, H.C.J.; Heads, P.A.; Lawler, S.; Magda, D.; Thomas, C.D.; et al. The Ecotron: A controlled environmental facility for the investigation of population and ecosystem processes. Philos. Trans. Biol. Sci. 1993, 341, 181-194. [CrossRef]

499. Eisenhauer, N.; Barnes, A.D.; Cesarz, S.; Craven, D.; Ferlian, O.; Gottschall, F.; Hines, J.; Sendek, A.; Siebert, J.; Thakur, M.P.; et al. Biodiversity-ecosystem function experiments reveal the mechanisms underlying the consequences of biodiversity change in real world ecosystems. J. Veg. Sci. 2016, 27, 1061-1070. [CrossRef]

500. Hyperspectral Infrared Imager-HyspIRI. Available online: http://hyspiri.jpl.nasa.gov (accessed on 15 December 2016).

501. ECOsystem Spaceborne Thermal Radiometer Experiment on Space Station-ECOSTRESS. Available online: https:/ / ecostress.jpl.nasa.gov (accessed on 15 December 2016).

502. Lee, C.M.; Cable, M.L.; Hook, S.J.; Green, R.O.; Ustin, S.L.; Mandl, D.J.; Middleton, E.M. An introduction to the NASA Hyperspectral InfraRed Imager (HyspIRI) mission and preparatory activities. Remote Sens. Environ. 2015, 167, 6-19. [CrossRef]

503. Houborg, R.; Fisher, J.B.; Skidmore, A.K. Advances in remote sensing of vegetation function and traits. Int. J. Appl. Earth Obs. Geoinf. 2015, 43, 1-6. [CrossRef]

(C) 2016 by the authors; licensee MDPI, Basel, Switzerland. This article is an open access article distributed under the terms and conditions of the Creative Commons Attribution (CC-BY) license (http://creativecommons.org/licenses/by/4.0/). 